\title{
As Condições de Possibilidade da Ciência da Natureza Humana: Crítica da Metafísica e Ciência do Homem
}

Tese apresentada no departamento de Filosofia da FFLCH - USP para a obtenção do grau de doutor em filosofia.

Orientação Prof. Dr. Carlos Alberto Ribeiro de Moura

Candidato: Fernão de Oliveira Salles dos Santos Cruz 
Resumo e Abstract

03

Apresentação

04

Capítulo 1: "Uma Alteração total da Filosofia"

10

Capítulo 2: A Composição da Experiência e o "Cimento do Universo" 34

Capítulo 3: Uma Nova Definição de Necessidade

Capítulo 4: Ilusões Naturais e Ficções Metafísicas

Conclusão 


\section{Resumo}

Desde sua primeira obra, David Hume anuncia ao leitor o projeto de constituição de uma ciência da natureza humana. O principal objetivo deste trabalho consiste em examinar os argumentos utilizados por Hume para construir as condições de possibilidade desse saber.

\section{Abstract}

Since his first work David Hume announces his intentions to constitute a science of human nature. The main target of this thesis is to examine the arguments used by Hume to build the conditions of possibility of this field of knowledge. 


\section{Apresentação}

O resultado geral do comentário humiano da relação de causalidade é bem conhecido e deu ensejo a leituras que celebrizaram Hume como o grande destruidor da metafísica. De fato, não há como discordar de que o pensamento humiano abrigue uma crítica aguda dessa parte da filosofia. As conclusões a que chegam o Tratado e a $1^{\text {a }}$ Investigação quanto à causalidade não deixam nenhum espaço, por restrito que seja, à idéia de necessidade tal como concebida pela metafísica clássica.

De acordo com esses textos, é pela conjunção constante dos objetos dos sentidos e pela ação do hábito que a imaginação é determinada a relacioná-los como causa e efeito. A inferência causal não é tributária da descoberta de qualquer nexo essencial entre os objetos que ela relaciona, mas sim dos efeitos da conjunção constante e do hábito sobre a imaginação. Assim, a análise de Hume chega à conclusão de que a idéia metafísica de necessidade resulta de uma de uma impressão de reflexão produzida pelo hábito e pela conjunção constante de dois objetos semelhantes. E seu sentido metafísico fica reduzido a uma ficção derivada de uma tendência natural da imaginação a projetar sobre o domínio dos objetos sensíveis as relações estabelecidas na mente. A necessidade, diz o próprio Hume no Tratado, "(...) é apenas aquela determinação do pensamento de passar das causas aos efeitos e dos efeitos às causas, de acordo com sua união observada na experiência". (TNH, p.166) ${ }^{1}$

Essa conclusão negativa está decerto presente em Hume. E, sem dúvida, ela estava sendo gestada desde o momento em que, no Tratado

\footnotetext{
${ }^{1}$ Citamos segundo a paginação da edição Selby-Bigge/Nidditch. Oxford University Press, 1978.
} 
da Natureza Humana e, posteriormente, na Investigação sobre o Entendimento Humano, Hume insistia em afirmar a diferença de gênero entre o conhecimento das questões de fato e das relações de idéias, ou probabilidade e conhecimento. Desse ponto de vista, a análise da causalidade viria a desdobrar as conseqüências negativas dessa distinção que, ao fim e ao cabo, levariam Hume a proscrever a metafísica do domínio do conhecimento. E não haveria melhor corroboração dessa leitura da filosofia de $\mathrm{Hume}^{2}$ que o parágrafo final da Investigação:

Se temos em mãos um volume de teologia ou de metafísica das escolas, por exemplo, perguntemo-nos: contém ele raciocínios acerca de quantidade ou de número? Não. Contém ele raciocínios experimentais, acerca de questões de fato e de existência? Não. Lancemo-lo então às chamas, pois tudo o que ele contém são sofismas e ilusões. (Investigação sobre o entendimento humano, p.165) ${ }^{3}$

Essa análise tem, decerto, seus méritos e ressalta um aspecto importante da filosofia de Hume. Todavia, não faltam razões para desconfiar dessa leitura. Com efeito, por mais difícil que seja a compreensão de seu sistema, Hume nunca chegou realmente a esconder do leitor as suas "intenções" - para usarmos uma expressão de John Passmore 4 . Desde a publicação do Tratado da Natureza Humana, o projeto desenhado pelo filósofo escocês é mais abrangente que a simples recusa da metafísica. Trata-se, como se sabe, de elaborar uma ciência da natureza humana ou ciência do homem. Esse saber, somos avisados já na advertência ao leitor do Tratado, deve abranger o

\footnotetext{
${ }^{2}$ Cf. Passmore, J.A. Hume's Intentions, p. 70: "Ambos [Hume e os positivistas recentes] concordam que as doutrina metafísicas não devem ser condenadas como falsas, mas antes rejeitadas como sem significado."

${ }^{3}$ Citamos segundo a paginação da edição Nidditch. Oxford University Press, 1975.

${ }^{4}$ Passmore, que é um dos mais interessantes entre os comentadores de língua inglesa de Hume, dá à sua obra o nome de Hume's Intentions.
} 
entendimento, as paixões, a moral, a política e a crítica. Por que então colocar o acento de nossa leitura apenas na recusa da metafísica?

No Resumo do Tratado ficamos sabendo que o exame do entendimento humano, e com ele a discussão acerca da causalidade e da idéia de conexão necessária, é uma etapa da construção dessa ciência. Ele corresponde, nos termos de Hume, à sua lógica, pois, a "finalidade única da lógica é explicar os princípios e operações da nossa faculdade de raciocínio e a natureza de nossas idéias (...)." (Resumo do Tratado, p. 646) $)^{5}$ Cumprido esse estágio, a ciência do homem deve abranger a moral e a crítica, que tratam dos sentimentos do homem, e a política, que considera os homens em sociedade e em dependência uns em relação aos outros. ${ }^{6}$

Nesta tese tomamos como ponto de partida a sugestão feita por esses textos. Tentamos compreender o sentido da crítica humiana da metafísica tendo sempre no horizonte esse projeto maior. Tal perspectiva colocou para nós um problema que se tornou o alvo central de nosso trabalho e nos forneceu sua direção. Com efeito, a leitura da obra de Hume não deixa dúvidas quanto às suas conseqüências devastadoras para a metafísica clássica e para o ideal cartesiano de mathesis universalis. Mas quando a demolição de um paradigma de conhecimento está inscrita no projeto de constituição de uma ciência como a que Hume se propõe a inaugurar, impõe-se a tarefa de elaborar um outro que o substitua e torne possível o saber que se quer fundar.

Com isso em vista, tentamos reconstituir a argumentação do livro I do Tratado e da Investigação, buscando explicitar como o filósofo elabora as condições de possibilidade da ciência do homem. Procuramos examinar nela tanto aquilo que a filosofia de Hume rejeita quanto as

\footnotetext{
${ }^{5} \mathrm{O}$ título completo da obra é, como se sabe, Abstract of a Book Lately Published; intitled, A Treatise of Human Nature. Doravante nos referiremos a ela apenas como Resumo. Citamos segundo a paginação da edição Selby-Bigge/Nidditch. Oxford University Press, 1978.

${ }^{6}$ Cf. Resumo, p. 646.
} 
perspectivas que, a partir dessa recusa mesma, se abrem. Acreditamos que esse ângulo, conforme esperamos ter indicado aqui, permite dar um sentido mais completo à crítica humiana da metafísica e, além disso, delinear as feições mais gerais da ciência da natureza humana.

A estrutura deste trabalho reflete essa opção de análise. Assim, no capítulo I pretendemos definir, a partir de textos que podemos chamar de programáticos do autor, os contornos do projeto humiano e contrastá-lo com a tradição filosófica moderna, sobretudo a de língua inglesa. No capítulo II tentamos mostrar como o empirismo rigoroso de Hume toma como ponto de partida uma análise fenomenista e nominalista da própria composição da experiência e chega a problemas que deverão, numa primeira instância, ser solucionados através das relações naturais e da associação de idéias. Esses dois capítulos são importantes para nossa argumentação, pois é neles que pretendemos mostrar como se forma o quadro conceitual no qual a metafísica será problematizada.

É no interior desse cenário que despontam as discussões acerca da causalidade, da crença e da conexão necessária contidas no capítulo III desta tese. Ali tentamos mostrar como essas três temáticas emergem na filosofia humiana, bem como qual o sentido que os três conceitos a elas relativos adquirem no pensamento de Hume. Nossa intenção aqui é apenas a de refazer o argumento pelo qual o filósofo elabora uma nova noção de necessidade e um novo critério de evidência para nossas idéias a partir da crítica da concepção metafísica da causalidade.

A noção de crença e a solução da pergunta pela gênese da conexão necessária oferecem uma chave de explicação que Hume utilizará ao mostrar de que forma a metafísica, numa espécie de redobro das tendências naturais da imaginação, forja as ficções que emprega para articular o campo do conhecimento. Esse é o tema do 
quarto capítulo, onde procuramos identificar como Hume dá cabo da crítica desse saber, a partir da análise de duas idéias centrais que estão na base dessas ficções: a da existência dos objetos externos e a da identidade pessoal. Nele procuramos determinar dentro de quais limites essas duas idéias são passíveis de uma refutação pela filosofia, bem como até que ponto somos obrigados a aceitá-las como crenças naturais, derivadas de tendências da imaginação.

Concluímos este trabalho com uma análise das seções do Tratado e da Investigação que tratam da controvérsia acerca da liberdade e da necessidade. Retomando o "projeto de reconciliação" de Hume, procuramos mostrar qual o campo que se abre e como, ao desonerar a causalidade e a necessidade de toda carga ontológica e liberar o filósofo de qualquer referência ao conhecimento das substâncias, a filosofia humiana cria condições para o estudo das disciplinas que compõem a própria ciência do homem.

A conclusão desta tese doutoramento deve muito a diversos amigos e professores. Em primeiro lugar, ao longo de sua elaboração tive o privilégio de contar com a orientação rigorosa, aberta e generosa do professor Carlos Alberto Ribeiro de Moura. Minha dívida para com ele é inestimável. O professor Márcio Suzuki, além de amigo e interlocutor paciente, participou do exame de qualificação e contribuiu sensivelmente para que este trabalho tomasse forma. Agradeço também ao professor Franklin Leopoldo e Silva, cujas observações feitas naquela mesma ocasião foram valiosas para o andamento e a conclusão da tese.

Sou grato ainda a Pedro Paulo Pimenta, colega e amigo, pelas sugestões sempre perspicazes e o apoio fraterno. Também Luís Nascimento e os colegas do grupo de estudos das Luzes Britânicas, têm seu quinhão naquilo que esta tese tem de bom. Maria Helena e Marie, da secretaria do departamento de filosofia da USP, sempre estiveram 
disponíveis e prontas a ajudar nas questões burocráticas. Minha irmã, Ana Salles, e meu cunhado, Gabriel Madeira, providencialmente radicados em Chicago sempre estiveram presentes e forneceram boa parte da bibliografia aqui utilizada. Sou grato a meus pais, Maria Regina Campos de Oliveira e José Salles dos Santos Cruz, pelo apoio sempre carinhoso. Gostaria ainda de lembrar os amigos Douglas Ferreira de Barros, Eunice Ostrensky, Marisa Lopes e José Carlos Estevão, Maria Adriana Camargo Cappello e Marta Kawano.

Este trabalho é dedicado com amor à Mariana Fontes, minha esposa, que garantiu minha sanidade e "toureou" Teresa e Luísa ao longo dos momentos finais da redação. 


\section{Capítulo I - "Uma Alteração total da Filosofia"}

\section{I}

Ninguém desconhece que Hume atribui a seu próprio pensamento um caráter de absoluta novidade. Tal pretensão será exposta com todas as letras no Resumo do Tratado, publicado pouco após a constatação do conhecido fiasco editorial do Tratado da Natureza Humana. No prefácio do Resumo do Tratado - obra que se propunha a sintetizar as principais teses humianas e reverter a decepcionante recepção do livro inaugural do filósofo - Hume afirma que, apesar de sua repercussão pífia, o volume seria inteiramente original e, talvez, até mesmo uma obra revolucionária.

O [Tratado] me parece um livro suficientemente singular e inovador para chamar a atenção do público, ainda mais se constatarmos, como sugere o autor, que a aceitação de sua filosofia implica a alteração da maioria das ciências desde o fundamento. (Resumo, pp. 643-644)

Entre amigos, como Henry Home, Lorde Kames, ele não se mostra menos entusiasmado e assegura estar produzindo "uma alteração total da filosofia."7

Vale perguntar o que, no entanto, justificaria essa convicção do próprio Hume de que seu sistema se afigura como algo inteiramente novo na história da filosofia ${ }^{8}$. Ora, essa certeza já se manifesta na

\footnotetext{
${ }^{7}$ Cf. Mossner, E.C., The Life of David Hume, p. 113.

${ }^{8} \mathrm{Há}$ razões para supor que desde cedo Hume tivesse a pretensão a inaugurar um novo modo de fazer filosofia. Em sua conhecida carta ao célebre médico escocês George Cheyne, datada de março ou abril de 1734, ele relata que desde cedo (com cerca de 14 ou 15 anos de idade) percebeu crescer em si uma certa "ousadia (boldness) de temperamento" que não o inclinava a "submeter-se a autoridade alguma" e, pelo contrário, o levava a "buscar algum novo meio (Medium) através do qual a verdade pudesse ser estabelecida". A descrição é curiosa pois exprime um estado de espírito semelhante ao entusiasmo (no sentido em que o termo era empregado pelos contemporâneos de Hume) pela filosofia que, segundo o próprio autor, foi-lhe fonte de desconforto e angústia, levando-o a procurar o auxílio do Dr. Cheyne.
} 
abertura da introdução do Tratado, quando Hume assume um ponto de vista externo, analisa o conflito das filosofias e examina a situação desse saber. Nesses trechos iniciais, é notável que Hume tome a perspectiva que não é meramente a de alguém que pretende formular um novo sistema, mas de quem espera inaugurar um novo capítulo da história da filosofia, apresentando um novo modo de pensar que porá fim ao "conflito das filosofias."

É como quem se coloca de fora, realiza um diagnóstico, indica causas e delineia conseqüências da sucessão dos sistemas na história da filosofia que Hume apresenta ao leitor o projeto de sua obra. Em sua descrição do confronto entre as doutrinas filosóficas e dos danos que esse embate traz à própria filosofia Hume deixa claro a distinção entre o programa que está prestes a expor e o que até então caracterizou os movimentos observáveis na história desse saber. "Nada é mais usual e natural para aqueles que pretendem oferecer ao mundo novidades em filosofia e nas ciências do que louvar o próprio sistema depreciando todos aqueles precedentes." (TNH, p. xiii)

A história da filosofia é descrita como um longo embate que permanece sem solução.O cenário descrito por Hume é, por assim dizer, de "terra arrasada". Diante da constatação de que a ignorância prevalece mesmo nas questões mais importantes que são da alçada do "tribunal da razão humana", o choque contínuo dos diferentes sistemas tem como principal efeito o descrédito da filosofia e sua depreciação perante o público letrado.

É fácil para alguém dotado de juízo e instrução perceber quão frágeis são as fundações até mesmo dos sistemas mais consagrados, que foram reconhecidos em sua pretensão de conter raciocínios acurados e profundos. Princípios acolhidos com base na confiança, conseqüências deduzidas de modo defeituoso, falta de coerência entre as partes, e de evidência no todo - tudo isso encontra- 
se nos sistemas dos mais eminentes filósofos, e parece cobrir de opróbrio a própria filosofia. ( $T N H$, p. xiii)

A julgar pela análise de Hume, o resultado não poderia ser diferente. Além de serem evidentes até mesmo ao vulgo, a precariedade da filosofia e a "condição imperfeita das ciências" abrem caminho para a multiplicação das controvérsias que se decidem num embate que não pode ser vencido pela razão. Dada a fragilidade dos fundamentos, a falta de evidência do todo e de coerência entre as partes dos vários sistemas que se sucedem na história da filosofia, é a eloqüência que garante a vitória nessa controvérsia. Nas palavras do próprio Hume:

Em meio a todo esse alvoroço, não é a razão que leva o prêmio, mas a eloqüência; e nenhum homem precisa temer não conquistar prosélitos para as hipóteses mais extravagantes, se tiver habilidade suficiente para representá-las em cores mais atraentes. ( $T N H$, p. xiv)

É empregando uma metáfora militar - procedimento semelhante ao que utilizará mais adiante, quando for defender a posição central da ciência do homem - que Hume expressa o caráter meramente retórico ao qual se reduzem as querelas filosóficas. No confronto, dirá o filósofo escocês, a "vitória não é conquistada pelos homens de armas, que manejam o dardo e a espada, mas pelos corneteiros, tamborileiros e demais músicos do exército." ( $T N H$, p. xiv)

Essa situação coloca problemas que deverão ser enfrentados por um filósofo que, como Hume, pretende apresentar um pensamento inteiramente novo: ele terá de se haver com o "preconceito comum contra os raciocínios metafísicos de todas as espécies, mesmo entre aqueles que se dizem doutos" ${ }^{\prime \prime}$. A afirmação soa um tanto desconcertante, considerando-se que após descrever e condenar as

\footnotetext{
${ }^{9}$ Cf. $T N H$, p. xiv.
} 
disputas metafísicas Hume é obrigado a empreender o que poderia ser considerado como uma defesa da própria metafísica. Diante desse início do Tratado, como evitar um juízo semelhante ao de Beattie, que inclui Hume entre os "autores metafísicos de primeiro escalão (rank) da época" ${ }^{10}$ Essa classificação parece ao menos inusitada, sobretudo em se tratando de um autor que caracteriza sua filosofia como um "ceticismo mitigado".

É preciso evitar o mal-entendido. Antes de condenar o célebre cético escocês ou acusá-lo de um contraditório recuo metafísico cabe perguntar o que ele entende por "raciocínios metafísicos". A resposta de Hume no Tratado é simples e engenhosa. Não se trata de dar uma definição do que sejam esses raciocínios, mas apenas de descrever como os doutos e o vulgo os caracterizam, revelando um ponto de vista comum a ambos: "por raciocínios metafísicos não entendem eles um ramo particular das ciências, mas toda espécie de argumento que é em alguma medida abstruso e requer atenção para ser compreendido." ( $T N H$, p. xiv) Com efeito, não é apenas contra a metafísica em seu sentido técnico que o público - douto ou leigo - se opõe, mas a certo gênero de raciocínio presente nas ciências em geral e que lhes é mesmo indispensável. Tal recusa demanda, nos termos do Tratado, "o mais determinado ceticismo" e é extremamente perniciosa ao conhecimento.

Não por acaso, essas observações antecedem justamente 0 parágrafo em que se inicia a introdução do projeto filosófico de Hume propriamente dito. A posição desse tema na ordem de exposição do argumento humiano adverte o leitor de que ele se defrontará com raciocínios em algum grau abstrusos e indica que, em certa medida,

${ }^{10}$ Cf.texto citado em Malherbe La Philosophie Empiriste de David Hume, p.24. Sobre isso, cf. também Thomas Reid, An Inquiry into the Human Mind on th Principles of Common Sense, I, VII-VIII. 
esses raciocínios deverão ser admitidos numa filosofia que pretenda algum grau de precisão e profundidade.

Se a verdade está ao alcance da razão humana, ela deve se situar em lugar profundo e abstruso. Esperar alcançá-la sem maior esforço, quando os maiores gênios falharam ao cabo das piores dificuldades, é uma atitude que com toda razão deve ser considerada vã e presunçosa. De minha parte, eu não tenho a pretensão de que a filosofia aqui desenvolvida goze de tal privilégio; e, se ela fosse demasiado fácil e óbvia, eu teria bons motivos para descreditá-la. (TNH, p. xiv)

\section{II}

Ao menos à primeira vista, não é fácil conciliar essas passagens do Tratado com a seção I da Investigação sobre o Entendimento Humano onde, numa primeira leitura, Hume parece condenar integralmente toda filosofia calcada em raciocínios abstrusos e profundos. Com efeito, o ponto de partida dessa obra é justamente a conhecida distinção entre duas espécies de filosofia: a filosofia fácil e a filosofia abstrusa, sendo a segunda identificável com a metafísica ou, ao menos, impregnada dos chamados "raciocínios metafísicos". A distinção aparentemente ecoa a censura integral da metafísica pelos chamados "scriblerians" - Addison, Swift e Pope, entre outros ${ }^{11}$. Como esses autores, Hume irá condenar a pretensão da filosofia a penetrar em esferas inacessíveis ao entendimento humano, o desprezo pelo interesse prático do conhecimento e a linguagem obscura.

Diferentemente deles, no entanto, ele não identifica a metafísica apenas à filosofia tributária da escolástica, mas, também, ao racionalismo clássico aparentado ao cartesianismo. Além disso, e talvez mais importante, ao final do texto ele parece restituir algum lugar aos raciocínios abstrusos e distingue entre a boa e a má metafísica.

\footnotetext{
${ }^{11}$ Cf. M. A. Box, The Suasive Art of David Hume, pp.20-40.
} 
A filosofia fácil, dirá Hume, toma o homem como "nascido para a ação, e influenciado, em suas deliberações, por sentimento e gosto, perseguindo um objeto e evitando outro conforme o valor que pareçam ter e de acordo com a luz na qual eles se apresentam." (Investigação, p.5) Essa ênfase no aspecto ativo da natureza humana e na influência da afecção, do gosto e do sentimento, vai determinar tanto o alvo visado por essas filosofias quanto o modo de exposição de suas doutrinas.

O objetivo da filosofia fácil é eminentemente prático. A preocupação de seus autores não é tanto a de descobrir os princípios regulam a natureza humana, mas, sobretudo, a de produzir certos efeitos nos homens. Em outras palavras, sua meta não é apenas instruir, mas reformar a conduta do leitor. Por essa razão, os filósofos dessa espécie esforçam-se para despertar no público o interesse pela virtude e, por assim dizer, por colocá-lo no caminho correto. Nos termos de Hume, trata-se de "pintar a virtude nas cores mais agradáveis", "agradar a imaginação e cativar os afetos (engage the affections)." Assim, seus temas são tratados da forma mais "fácil e óbvia"12, retirando para seu uso elementos do cotidiano. Não por acaso, esse gênero de filósofo censurará no metafísico não só a obscuridade de seu saber, como seu interesse por questões meramente especulativas que não dizem respeito diretamente ao aprimoramento moral do público.

Numa filosofia como essa, o discurso endereça-se, sobretudo, ao gosto e ao sentimento (sentiment), e, por isso, as ferramentas empregadas são justamente os artifícios da retórica, os recursos da poesia e os exemplos ilustres. Com efeito, trata-se de "inculcar preceitos" e, principalmente, de "nos fazer sentir a diferença entre a virtude e o vício", excitando e regulando nossos sentimentos ${ }^{13}$.

${ }^{12}$ Cf. Investigação, p. 5.
${ }^{13}$ Cf. Investigação, p. 6. 
Na filosofia abstrusa, por sua vez, considera-se o homem antes de tudo como ser dotado de razão e, por conseguinte, sua tarefa não é a do cultivo das maneiras (manners), mas o conhecimento. Novamente, enquanto na filosofia fácil a natureza humana é considerada de um ponto de vista acima de tudo prático, aqui ela é apenas objeto de especulação. A pretensão do filósofo dessa segunda espécie é a de examinar seu objeto para, nas palavras de Hume, "discernir os princípios que regulam nosso entendimento, excitam nossos sentimentos e fazem-nos aprovar, censurar ou condenar um objeto, ação ou conduta." (Investigação, p.6)

Por isso, enquanto a filosofia fácil tira proveito dos artifícios da eloqüência e dos recursos da poesia, sua contraparte abstrusa lança mão do método que, grosso modo, poderíamos chamar de indutivo: os filósofos abstrusos procuram determinar princípios gerais a partir de casos particulares, "não se dando por satisfeitos até que atinjam aqueles princípios originais que, em qualquer ciência, impõem um limite a toda curiosidade humana". (Investigação, p.6). Sobretudo pelo nível de abstração que ela envolve e pela obscuridade da linguagem que the é congênita, uma filosofia desse gênero não se dirige ao público leigo, mas ao douto. Tais características explicam sua impopularidade e abrem, como se verá adiante, a possibilidade de que a filosofia profunda coloque-se a serviço da superstição.

O repúdio à filosofia abstrusa é explicado, também, em termos que remetem à própria natureza humana. Distante dos assuntos da vida comum e dos princípios que atuam sobre os homens, a filosofia profunda é fruto de uma disposição particular da mente que cessa quando se interrompe seu estudo e tem pouca ou nenhuma influência sobre nossa conduta. Mais que isso, como dirá Hume adiante, ela parece ser natural, mas apenas para alguns poucos homens dotados de um caráter específico. E mesmo estes, quando voltam aos assuntos da vida 
cotidiana, são afetados por sentimentos e paixões que dissipam a força de todas as suas conclusões: "os sentimentos de nosso coração, a agitação de nossas paixões e a veemência de nossas afecções dissipam todas as conclusões e reduzem o filósofo ao mero plebeu." (Investigação, p.7)

Se isso é o que ocorre com o filósofo profundo quando retorna à vida comum, o destino de suas obras não é mais auspicioso. Seus sistemas terão uma reputação momentânea fundada mais no "capricho ou na ignorância de sua própria época", que em seus próprios méritos. E, por isso, pensadores como Aristóteles, Malebranche e Locke, terão fama restrita a seu tempo, enquanto autores como Cícero, La Bruyère e Addison serão admirados pela posteridade.

Na filosofia fácil ocorre justamente o contrário. Em primeiro lugar, a propensão ao erro aqui é menor, pois o que se pretende é representar o senso comum dos homens nas "cores mais belas e cativantes". Em segundo, não ocorre aqui aquela multiplicação dos erros. Com efeito, pautado sempre pelo senso comum e pelos "sentimentos naturais da mente", o moralista sempre irá retornar à "trilha correta" e estará sempre protegido de quaisquer "ilusões perigosas".

E não é apenas à filosofia profunda que se faz justas censuras. Também, o filósofo que se dedica esse gênero filosófico é objeto de reprovação. Um caráter estritamente filosófico, dirá Hume, é "pouco aceitável no mundo", pois, isolado em suas sutilezas incompreensíveis para o comum dos homens, ele em nada parece contribuir para "o prazer ou vantagem da sociedade"14. Mas, se é verdade que o homem dotado de caráter puramente filosófico é objeto de justa reprovação, é preciso reconhecer que seu oposto, o ignorante, é ainda mais

${ }^{14}$ Sobre isso cf. Investigação, p.8. 
censurável. A ignorância será percebida com uma espécie de inadequação do homem, ao país e o espírito do século das luzes.

Por outro lado, o mero ignorante é ainda mais desprezível. Numa época e nação em que as ciências florescem, considera-se que não há sinal mais certo de um gênio iliberal do que ser inteiramente desprovido de gosto por esses entretenimentos mais nobres. (Investigação, p.8)

O ignorante e o mero filósofo, dirá Hume, são os extremos da variedade de caracteres possíveis. Como tais, eles estão igualmente distantes do que seria um caráter perfeito, mas, por isso mesmo, servem de baliza para que se possa determinar aonde se situa essa perfeição. Como o próprio Hume fará questão de ressaltar mais adiante, o interesse de alguns pelo pensamento abstruso é em certa medida natural. Do ponto de vista de sua constituição, o filósofo profundo é similar a aqueles indivíduos que, dotados de grande vigor físico, dedicam-se e, até mesmo, necessitam de exercícios que seriam fatigantes para a maior parte dos homens. Contudo,

Supõe-se que o caráter mais perfeito estaria situado entre esses dois extremos: tendo uma mesma habilidade para o gosto e os livros, para a companhia e os negócios, mostrando, na conversação, o discernimento e delicadeza que são despertados pelo cultivo das belas-letras, e, nos negócios, aquela probidade e precisão que são o resultado natural de uma filosofia justa. (Investigação, p.8)

$\mathrm{Na}$ formação desse caráter vê-se qual deve ser a função da filosofia.

Para difundir e cultivar um caráter tão completo nada é tão útil quanto composições de maneira e estilo fácil, que não se afastam muito da vida, que não demandam, para ser compreendidas, aplicação profunda nem isolamento, de tal maneira que devolvem o estudioso aos homens, cheio de sentimentos nobres e preceitos sábios, aplicáveis às exigências da vida humana. Por meio 
dessas composições, a virtude se torna amável, a ciência, agradável, a companhia, instrutiva, e o isolamento, aprazível. (Investigação, p.8)

Aqui é possível divisar onde se situa a principal virtude da filosofia fácil. Não é só por sua utilidade, mas também por sua adequação que a natureza multifacetada do homem e às limitações de seu entendimento. Como ser racional, o homem precisa nutrir-se de ciência. Mas, dados limites estreitos de seu entendimento, é necessário moderar esse regime. Todavia, o homem é também naturalmente sociável e necessita do convívio e da companhia. Além disso, sua natureza é ativa e as necessidades da vida demandam ocupações e negócios.

O caráter mais bem acabado deve equilibrar todas essas tendências, inscritas na própria natureza humana, de modo a impedir que uma delas se sobreponha às restantes, incapacitando os homens de entregaram-se às outras ocupações e entretenimentos. Instituir esse caráter balanceado é função que pode ser cumprida pela filosofia fácil, mas não pela abstrusa. Na forma de um mandamento da natureza Hume indica o difícil equilíbrio a que a ciência deve estar submetida. A paixão pela ciência deve ser satisfeita, mas essa deve ser uma ciência humana e "como tal ter uma referência direta à ação e à sociedade. (...) Sê filósofo, mas em meio a toda sua filosofia, sê ainda homem." (Investigação, p.9) E, contra a exacerbação da inclinação ao conhecimento e da especulação, ou da paixão pela ciência, como diz Hume, a melancolia que pesa sobre o filósofo abstruso será mais uma advertência da própria natureza.

A filosofia abstrusa parece, portanto, irremediavelmente condenada. Mas o que dizer de certos autores abstrusos aos quais aos quais Hume rende homenagem em outras obras e dos quais sua filosofia 
é francamente tributária? Esse é o caso, por exemplo, de Locke - citado no texto como filósofo abstruso em contraposição a Addison ${ }^{15}$.

De fato, após recensear as críticas feitas á esse gênero de filosofia e ressaltar os inconvenientes que Ihe são inerentes, Hume irá indicar que o veredicto precisa ser, por assim dizer, temperado. Ora, ainda na seção I da Investigação, através de uma analogia entre os dois gêneros de filosofia, a pintura e a anatomia, Hume poderá matizar essa recusa da filosofia profunda e dos raciocínios abstrusos.

O anatomista oferece aos olhos objetos hediondos e desagradáveis, mas sua ciência é útil ao pintor que queira delinear uma Vênus ou Helena. Pois este, quando emprega as mais ricas cores de sua arte e dá às figuras os ares mais graciosos e atraentes, deve se manter atento à estrutura interna do corpo humano, à posição dos músculos, ao esqueleto ósseo, à configuração e função de cada parte ou órgão. (Investigação, p.10)

O que a comparação parece mostrar é que não se trata de simplesmente rejeitar a filosofia abstrusa em favor da filosofia fácil. Com efeito, a atividade do moralista envolve a realização de um retrato da natureza humana. E, ainda que ela seja determinada por objetivos essencialmente práticos, a composição correta desse quadro requer uma exatidão e uma precisão que implicam o conhecimento acurado e profundo do homem. Do mesmo modo que o pintor se beneficia do exame preciso e fatigante do corpo humano realizado pelo anatomista, o autor que se dedica à filosofia fácil deve tirar proveito da investigação empreendida pelos "filósofos profundos"16.

\footnotetext{
${ }^{15}$ Cf. Investigação, 1 , p. 7; TNH, p. xvii, nota 1.

${ }^{16}$ Não é apenas a serviço da filosofia fácil que os raciocínios difíceis e profundos têm algum emprego e encontram um lugar legítimo. Como prossegue Hume: "Além disso, podemos observar que em toda arte ou profissão, mesmo naquelas que concernem mais à vida ou ação, o espírito de precisão as aproxima de sua perfeição e as torna de maior serventia aos interesses da sociedade" (Investigação, p.10) Mesmo o filósofo, que vive afastado dos negócios humanos, pode ser de utilidade, na medida em que o "gênio da filosofia" quando cultivado por alguns se difunde em toda sociedade, disseminando sua correção por todas as artes e ofícios. Nessa
} 
É aí que se inscrevem legitimamente os raciocínios abstrusos, que o público deprecia sob a denominação geral de metafísica. Em mais essa reviravolta do sinuoso argumento de Hume, o conhecimento profundo e preciso dos princípios da natureza humana, almejado ao menos por parte da filosofia abstrusa, revela-se mesmo fundamental para as "composições em estilo e maneira fáceis". Afinal, como diz Hume, "a acuidade é, em todo caso, vantajosa para a beleza; o raciocínio justo, para o sentimento delicado. Em vão exaltaríamos um depreciando o outro." (Investigação, p. 10) Todavia, a exemplo do pintor, para produzir no leitor os efeitos práticos visados por sua arte - "sentimentos de louvor ou censura, de admiração ou ridículo" - o filósofo deverá retratar seu objeto em cores agradáveis e ocultar o trabalho penoso que levou ao conhecimento profundo da natureza humana ${ }^{17}$.

Mesmo assim, o texto de Hume aponta para o fato de que a utilidade da filosofia abstrusa não é suficiente para garantir-lhe direito de cidadania. O problema é que a obscuridade da filosofia profunda e abstrata é uma "inevitável fonte de incerteza e erro"18". A sutileza da investigação e uma disposição do filósofo para acolher conclusões que contradigam a opinião comum, fazem dos autores desses sistemas uma presa fácil de erros que, rigorosamente desdobrados em suas conseqüências lógicas, darão origem a outros equívocos, colocarão a perder toda a doutrina.

A esse diagnóstico negativo soma-se uma outra constatação: há uma parcela desse saber que surge ou dos

\footnotetext{
medida, a filosofia abstrusa pode contribuir para a arte da política, para a profissão do advogado e para o aprimoramento do estado.

${ }^{17}$ Não se trata apenas de uma questão de precisão em relação à descrição do objeto tratado pela filosofia fácil, mas, também, de conhecer a natureza humana para saber quais os artifícios necessários para produzir no leitor os efeitos desejados.

${ }^{18}$ Cf. Investigação, p. 11.
} 
esforços infrutíferos da vaidade humana, que quer penetrar em objetos inteiramente inacessíveis ao entendimento, ou da artimanha das superstições populares, que, incapazes de se defender em campo limpo, buscam arbustos cerrados para recobrir e esconder suas fraquezas. (Investigação, p.11)

Ou seja, por um lado, devido a seu caráter naturalmente obscuro, a metafísica pode servir de refúgio à superstição ${ }^{19}$. Por outro, ela se torna tanto mais nebulosa quanto mais o filósofo avança em direção a objetos que estão fora do alcance do entendimento humano.

A situação exposta por Hume configura-se como uma espécie de dilema. A filosofia fácil restringe-se a limites plenamente adequados aos poderes do entendimento humano. No entanto, sua tarefa parece pressupor, em alguma medida, o conhecimento profundo da natureza humana, tarefa que é da jurisdição da filosofia abstrusa. O problema é que essa seara é campo fértil para o erro, a obscuridade e a superstição.

Essas constatações não implicam porém o abandono completo da investigação profunda da natureza humana. Pelo contrário, Hume é enfático ao ressaltar a necessidade de combater a superstição em seu próprio campo e libertar o conhecimento do erro e da obscuridade.

O único método eficaz para libertar o saber, de uma vez por todas, de questões abstrusas, é investigar a sério a natureza do entendimento humano e mostrar, por uma análise exata de suas capacidades e poderes, que ele de modo algum é talhado para tópicos tão remotos e abstrusos. Devemos nos submeter a essa fadiga, para então viver com tranqüilidade; devemos cultivar com carinho a verdadeira metafísica, para destruir a falsa e adulterada. (Investigação, p.12)

\footnotetext{
${ }^{19} \mathrm{Nem}$ por isso parece acertado afirmar, como o faz Stephen Buckle em Hume's Elightenment Tract, que, na Investigação, há uma mudança radical de orientação, em relação ao Tratado. É exagerado inferir, a partir da referência explicita de Hume à superstição e das seções X e XI da obra, que se trata, como quer o comentador, de um livro escrito contra a religião e, mais especificamente, contra o catolicismo e o protestantismo. Em vez de pretender uma renovação da filosofia a partir de suas bases Hume estaria empreendendo uma crítica da religião cristã em todas as suas modalidades e, apenas secundariamente, da escolástica que fornecia lastro ao catolicismo.
} 
Essa passagem pode suscitar a impressão de contradição. Afinal, há pouco Hume endossava a necessidade e a utilizada da filosofia profunda para a filosofia fácil. É preciso atentar, porém, para a para o fato de que não se trata de avalizar as questões da filosofia profunda em sua totalidade. O remédio que Hume prescreve para combater a obscuridade e o erro da metafísica é a análise acurada dos princípios da natureza humana e a determinação dos limites de nosso entendimento. E não é surpreendente que essa empreitada envolva, em alguma medida, raciocínios abstrusos e uma investigação profunda.

Não por acaso, as palavras que encerram a seção I expressam a intenção do autor de promover uma reconciliação e a recusa de uma oposição irredutível entre os dois gêneros de filosofia.

Qual não será a nossa felicidade se pudermos unir as fronteiras das diferentes espécies de filosofia, reconciliando a investigação profunda com a clareza, e a verdade com a novidade! E não seríamos ainda mais felizes, se raciocinando de maneira simples pudéssemos minar as fundações de uma filosofia abstrusa que serviu apenas para dar abrigo à superstição e proteger o absurdo e o erro? (Investigação, p.16)

Essas poucas linhas assinalam a posição singular que a filosofia humiana assume perante duas tradições. Ao mesmo tempo em que rejeita a metafísica clássica por sua obscuridade e reconhece a existência de limites para a especulação o filósofo escocês distingue-se dos mais ferrenhos críticos dessa tradição, pois admite a necessidade de alguma especulação profunda. O desafio assumido por Hume bem poderia ser ilustrado como sendo o de unir numa mesma filosofia a profundidade da investigação proposta por um filósofo como Locke com a elegância e a clareza de um autor como Addison. 


\section{III}

Como promover essa reconciliação? A preocupação em reunir as virtudes das duas espécies de filosofia está presente desde a escritura do Tratado, embora naquele momento ao que Hume expressasse descrença quanto às possibilidades de êxito dessa empreitada. Em carta a Hutcheson, datada de aproximadamente 1739, Hume já tematizava esse problema.

Há diferentes modos de examinar a mente, a exemplo do corpo. Pode-se considerá-los seja como anatomista, seja como pintor, para descobrir suas mais secretas molas e princípios ou a graça e beleza de suas ações. Eu imagino que seja impossível conjugar essas duas perspectivas (...) Mas o anatomista tem bons conselhos a dar ao pintor ou escultor. Da mesma maneira, estou persuadido que o metafísico pode ser muito útil ao moralista, embora eu não possa conceber esses dois caracteres unidos na mesma obra. ${ }^{20}$

Não obstante as desconfianças do filósofo nesse momento, boa parte do caminho para solucionar esse problema já estava dado desde o inicio do projeto de realizar uma ciência do homem, anunciado no Tratado. Desde essa obra, Hume vê no estudo da natureza humana uma arma para eliminar as controvérsias entre os sistemas, que reduzem a filosofia a um estado de extrema precariedade, a tornam obscura e suscitam censuras severas tanto da parte do público leigo, quanto do douto.

Além de constituir um remédio para as controvérsias filosóficas, o exame da natureza humana justifica-se por si mesmo como objeto privilegiado da filosofia. Com efeito, a ciência da natureza humana será a única capaz de fornecer os limites e determinar o fundamento dos outros ramos do conhecimento, pondo fim ao confronto entre sistemas filosóficos. A metáfora empregada por Hume no Tratado

${ }^{20}$ Carta a Hutcheson, in: The Letters of David Hume, Letter 13, vol. I, pp. 32-33. 
expressa com precisão a posição central e o papel da ciência do homem:

Eis portanto o único expediente do qual podemos esperar algum êxito em nossas pesquisas filosóficas: abandonar o tedioso e hesitante método que seguimos até agora, e, em vez de tomarmos um castelo ou uma vila fronteiriça, marcharmos direto para a capital ou centro das ciências, para a natureza humana - a partir da qual, uma vez que dela sejamos mestres, poderemos esperar vitória fácil em qualquer outro lugar. ( $T N H, \mathrm{p} . x \mathrm{i}$ )

Para garantir a ocupação deste país deve-se assegurar o domínio da capital. No conjunto das ciências, a ciência da natureza humana ocupa o centro e sua relação com os outros ramos do conhecimento é análoga à da capital com suas províncias.

A imagem é precisa e exprime bem a posição da ciência do homem no quadro do conhecimento, mas dá margens a considerá-la como um mero substituto da metafísica na fundação das demais ciências $^{21}$. Cabe perguntar, por exemplo, o que diferencia a metáfora de Hume da célebre imagem cartesiana da árvore do conhecimento, cuja raiz e o fundamento seriam justamente a metafísica?

Uma diferença, ao menos, é evidente: ao contrário do que ocorre com a metafísica cartesiana, a ciência da natureza humana não desempenha o papel de legitimar o conhecimento através da ontologia ou da teologia. Tampouco se trata de examinar a natureza do homem tomando como ponto de partida um eu racional, situado fora da natureza e dela independente. Trata-se aqui de assumir um novo ponto de vista que considera o homem como inserido na natureza e

\footnotetext{
${ }^{21}$ Há autores como Passmore, por exemplo, que chamam a atenção para uma certa semelhança entre o lugar ocupado pela metafísica na imagem cartesiana da árvore do conhecimento e o lugar que ciência da natureza humana ocupa na filosofia humiana. Segundo ele, a diferença entre os dois seria o fato de que a última, e não a primeira, é que se colocaria nas raízes da árvore do conhecimento no caso Hume. Cf. Passmore, Hume's Intentions, p.12.
} 
que toma, como início da reflexão filosófica, a própria natureza humana ${ }^{22}$. Diferentemente do racionalismo clássico - que propunha um dualismo entre uma parte animal do homem submetida às determinações naturais e outra puramente racional, livre desses constrangimentos ${ }^{23}$-, o pensamento humiano considera 0 homem submetido em sua totalidade a determinações naturais.

Ademais, a ciência do homem é ao mesmo tempo ciência fundadora e ciência entre as outras ciências. Se todos os saberes se reenviam a ela, é porque, em alguma medida, eles dependem das faculdades e poderes da mente ${ }^{24}$. Todavia, mesmo estando inscrita numa tópica corrente das chamadas Luzes Britânicas, a "geografia mental" de Hume não deve, tampouco, ser confundida com o estudo da natureza humana conduzido por contemporâneos seus, tais como Francis Hutcheson. Se Hutcheson coloca o estudo da natureza humana no centro de sua filosofia, não é por sua relação com as demais ciências. Diferentemente de Hume, ele o faz principalmente na medida em que conhecer nossa natureza é a melhor maneira de compreender qual a propósito da natureza em relação ao homem. Como se lê em Breve Introdução para a Filosofia Moral:

A intenção da natureza em relação a nós se mostra no exame de quais são as coisas que nos são recomendadas por nossos sentidos naturais ou poderes de percepção, e de quais, dentre elas, são as mais excelentes, e, a seguir, de quais são os alvos de nossos desejos naturais e de quais deles são os mais importantes à nossa felicidade. (Breve Introdução, p. 02)

\footnotetext{
${ }^{22}$ Cf. Michaud, Hume et la Fin de la Philosophie, p.13.

23 Conforme comenta Michaud: "Ao contrário, na perspectiva de uma ciência da natureza humana deve-se admitir a submissão da totalidade do humano ao natural. O que implica uma deflação das pretensões da razão e uma considerável extensão da idéia de humano." Michaud, Hume et la Fin de la Philosophie, p.16.

${ }^{24}$ Cf. Michaud, Hume et la Fin de la Philosophie, pp.14 -15.
} 
Dificilmente se encontrará na formulação do projeto filosófico de Hume tal pressuposto teleológico. Pelo contrário, um dos resultados conhecidos de sua filosofia é a crítica aguda do finalismo, apresentada primeiramente na seção XI da Investigação e posteriormente desenvolvida nos Diálogos sobre a Religião Natural. Nem ponto de partida, nem conseqüência do sistema, a teleologia é antes um dos alvos das investidas humianas contra a metafísica clássica. ${ }^{25}$

Mas não é só no que concerne ao lugar a ser preenchido pela ciência da natureza humana que se justifica a pretensão de Hume a originalidade. Como já vimos, através da ciência da natureza humana, Hume pretende apenas realizar uma "geografia da mente", mapear e conhecer as operações da mente humana. Com efeito, procedendo como o anatomista, o filósofo deverá isolar os elementos que se encontram no espírito humano e desvendar como esses elementos operam e se relacionam. Entretanto, dado que não conhecemos a essência da mente, devemos agir como o físico newtoniano que, desconhecendo a essência dos fenômenos que estuda, procura apenas observar e constatar as regularidades de seu comportamento. Como diz Hume no Tratado:

Parece-me evidente que, sendo a essência da mente tão desconhecida para nós quanto a dos corpos externos, igualmente impossível é formar qualquer noção de seus poderes ou qualidades de outra forma que não a partir de experimentos cuidadosos e acurados e da observação dos efeitos particulares que resultam de suas diferentes circunstâncias e situações. (TNH, p.xvii)

Agindo deste modo, os filósofos da natureza são capazes de descobrir leis gerais a partir de fatos observáveis para explicar o conjunto de

\footnotetext{
${ }^{25}$ Ver carta a Hutcheson, op. cit., p. 109: "I cannot agree with your sense of natural; it is founded on final causes; which is a consideration, which appears to me pretty uncertain and unphilosophical".
} 
objetos estudados. Seguindo seu exemplo, a ciência da natureza humana deve tomar a experiência como ponto de partida do conhecimento e descrever as regularidades observáveis. A partir daí deve, também, isolar princípios gerais ao compor o seu corpo de conhecimento.

A adoção dessa maneira de proceder tem implicações decisivas para a ciência da natureza humana. A escolha do método newtoniano implica a rejeição de um certo modelo de ciência, peculiar ao século XVII. Feita a opção pelo newtonianismo, o filósofo não mais irá constituir seu sistema através de uma série dedutiva que se estende do princípio mais elevado até suas conseqüências mais remotas, unindo todos os elos da cadeia do conhecimento.

A recusa das chamadas hipóteses metafísicas ${ }^{26}$ tem esse sentido e impõe um outro itinerário para a construção de um sistema. Para um filósofo newtoniano, o método não consistirá mais na pura dedução a partir de axiomas estabelecidos a priori, mas na análise de regularidades empíricas, a partir das quais os princípios serão de seu sistema serão determinados ${ }^{27}$. Em vez de deduzir as conseqüências das chamadas hipóteses metafísicas, o filósofo recorrerá à experiência e irá dos fatos aos princípios ${ }^{28}$.

\footnotetext{
${ }^{26}$ Conforme mostra Michaud, essa recusa é um dos pontos sobre os quais se estabelece a superioridade da física newtoniana sobre a cartesiana: "Todos os comentadores dizem: ele teve a modéstia de proceder dos fenômenos aos princípios em lugar de deduzir, a partir de alguns princípios imaginados, todos os fenômenos do mundo como o faziam os cartesianos." (Hume et la Fin de la Philosophie, pp.36-37) A este respeito conferir ainda: Noxon, Hume's Philosophical Development, p.3.

${ }^{27}$ Nas palavras de Cassirer: "Seus fenômenos são os dados da experiência, seus princípios a meta da investigação. Se os últimos são os primeiros de acordo com a natureza, os primeiros (former) serão sempre primeiros (first) para nós". (Philosophy of the Enlightenment, p.7)

${ }^{28}$ Sobre um certo fenomenismo inscrito na ciência newtoniana e que se reproduzirá na no método experimental de Hume de cf. Malherbe, La Philosophie Empiriste de David Hume, p. 38: "Com efeito, o que a ciência estuda é fenômeno, quer dizer, o que aparece, o que se mostra distintamente. Fenômeno se opõe a hipótese, mas, também, à experiência sensível qualitativa que, por sua variedade, é sempre luz e sombra que de uma só vez dá imediatamente e esconde uma natureza oculta."
} 
Mas não é só por definir o ponto inicial da investigação que essa opção metodológica é determinante para a constituição da ciência do homem. Ela não só implica um itinerário a ser seguido, mas demarca limites claros à investigação. A adoção do modelo newtoniano de ciência acarreta uma restrição considerável do campo do conhecimento, em favor da precisão e da recusa da arbitrariedade das hipóteses metafísicas que marcam - do ponto de vista de Hume e de outros pensadores do século XVIII - a ciência de matriz cartesiana ${ }^{29}$. O conhecimento não só deve começar pela experiência, como está impossibilitado de avançar para além dela. Isso significa que a ciência do homem, ao contrário da metafísica clássica, abandonará a pretensão a determinar os princípios últimos da natureza humana. Como afirma Hume na introdução do Tratado:

\begin{abstract}
Embora devamos nos esforçar para tornar nossos princípios tão universais quanto possível, remetendo os experimentos a suas fontes e explicando $s$ efeitos pelas causas mais simples e menos numerosas, é certo que nós não podemos ir além da experiência, e qualquer hipótese que pretenda descobrir as últimas qualidades originais da natureza humana deve ser de antemão rechaçada, por presunçosa e quimérica. ( $T N H$, p.xvii)
\end{abstract}

Essa restrição não só evita a arbitrariedade e o dogmatismo como se inscreve no que Malherbe qualifica acertadamente como sendo um certo "ideal de precisão" esposado pela filosofia humiana ${ }^{30}$. 0 empirismo radical de Hume vai localizar na experiência a fonte a garantia dessa

\footnotetext{
${ }^{29}$ Nesse sentido, vale lembrar as palavras de um outro admirador de Newton comentando a filosofia e a ciência de Descartes: "A geometria era um guia que de algum modo ele próprio havia formado, e que poderia tê-lo conduzido com segurança na física; no entanto, abandonou o guia em favor do espírito de sistema. A partir de então, sua filosofia foi apenas um romance engenhoso e, quando muito, verossímil para os ignorantes. Enganou-se a respeito da natureza da alma, das provas da existência de Deus, da matéria, das leis do movimento, da natureza luz. Admitiu idéias inatas, inventou novos elementos, criou um mundo, fez o homem à sua moda, e com razão diz-se que o homem de Descartes é apenas o de Descartes, muito distante do homem verdadeiro." Voltaire, Cartas Inglesas, 15a Carta, pp.24-25.

${ }^{30}$ Cf. Malherbe, 32-33.
} 
precisão que the permite superar as dificuldades que marcam a história da filosofia até então. É do recurso à experiência realizado em moldes newtonianos que emana a garantia de que - ao contrário do que ocorria com os sistemas filosóficos aos quais Hume se refere no início da introdução - essa filosofia pode arrogar-se o título de ciência. Como diz o autor na introdução: "a ciência do homem é a única fundação sólida das outras ciências, e o único fundamento sólido que podemos dar a essa ciência é a experiência e a observação." (TNH, p. xvi)

É verdade que Hume reconhece os méritos de Bacon, Locke, Shaftesbury, Butler, Mandeville e Hutcheson, por terem percebido a importância da experiência no estudo da natureza humana. Mas, por espelhar-se na ciência newtoniana, ele pode considerar-se como primeiro autor equipado com os instrumentos necessários para garantir a cientificidade desse estudo. Se no Tratado o elogio à filosofia da natureza, que vem em seguida à menção desses autores, demonstra bem esse ponto, a Investigação é ainda mais enfática:

Mas não nos será lícito esperar que a filosofia, cultivada com esmero e encorajada pela atenção do público, possa avançar ainda mais em suas investigações e revelar, pelo menos até certo ponto, os móveis e princípios ocultos que impulsionam a mente humana em suas ações? Os astrônomos se contentaram por muito tempo em deduzir dos fenômenos visíveis o verdadeiro movimento, ordem e magnitude dos corpos celestes, até que finalmente surgiu um filósofo, que, pelos mais afortunados raciocínios, parece ter determinado também as leis e forças que governam e dirigem as revoluções dos planetas. Resultados semelhantes têm sido alcançados em outros domínios da natureza. E não há razão para não esperarmos um igual sucesso em relação a nossas investigações acercas dos poderes e da organização da mente, se levadas a cabo com a mesma competência e precaução. (Investigação, p. 14).

Está dada aqui a via para superar a dicotomia entre a filosofia abstrusa e a filosofia fácil. A adoção do método newtoniano, o repúdio 
às hipóteses metafísicas e a consciência dos limites do conhecimento permitem a Hume superar a obscuridade da filosofia abstrusa sem ser obrigado a renunciar à especulação sistemática. Assim como no caso da física, o método de Newton permitirá a Hume proceder com precisão e dotar sua ciência de sistematicidade.

Quanto a isso, Hume vê a possibilidade de superar os autores antigos que, embora elogiados nos primeiros parágrafos do Resumo do Tratado por seu refinamento, estilo, e senso moral, são alvo de críticas devido à falta de profundidade e ao caráter marcadamente nãosistemático de suas reflexões. De posse do método de Newton, Hume vislumbra a possibilidade de unir as qualidades positivas dos autores da antiguidade a uma precisão e sistematicidade propriamente científicas.

Vale a pena ao menos tentar descobrir se a ciência do homem não admite a mesma precisão que vemos ser possível em várias partes da filosofia da natureza. Parece que temos todas as razões do mundo para imaginar que ela pode atingir um grau máximo de exatidão. Se, ao examinar diversos fenômenos, descobrirmos que eles se reduzem a um princípio comum, e se formos capazes de remeter esse princípio a outro chegaremos finalmente àqueles poucos princípios dos quais todo o resto depende. $E$, mesmo que não possamos chegar aos princípios últimos, já é uma satisfação ir até onde as nossas faculdades nos permitem ir. (Resumo do Tratado , pp. 645-646)

A ciência da natureza humana não abdica de examinar os princípios que regulam as operações da mente, mas evita hipóteses arbitrárias e recusa a pretensão a revelar os princípios últimos da natureza do homem. Mas não se trata de afirmar que na ciência do homem se encontrará o mesmo gênero exato de precisão que na física-matemática dos modernos. 
Todavia, para consumar esse movimento faltaria, porém, ajustar a forma de exposição. Essa parece ser a questão que está no fundo da mudança de estilo que se observa na passagem do Tratado para a Investigação. Afinal, segundo o próprio Hume, os defeitos do Tratado não residem na doutrina, mas na "maneira". " Sempre considerei que meu insucesso na publicação do Tratado da Natureza Humana deveuse mais à maneira que à matéria (...)." (My own life, p. xxxv). Se no Tratado o autor está de posse de um método que the garante a precisão e a clareza ausentes na metafísica clássica e, assim, pode fazer filosofia profunda sem recair na obscuridade e nos erros característicos da filosofia abstrusa, na Investigação ele encontra a forma de exposição adequada a esse novo modo de pensar. ${ }^{31}$

\section{IV}

Contudo, a aplicação do método experimental aos assuntos morais envolve mais dificuldades que o emprego desse mesmo método na filosofia da natureza. O próprio Hume é o primeiro a reconhecer que na filosofia moral, diferentemente do que ocorre na filosofia da natureza, é mais difícil coletar experimentos e realizá-los "propositadamente" e com "premeditação". Nesse território, é difícil ao filósofo até mesmo garantir a objetividade da observação dos dados empíricos. Afinal, a "reflexão" e a "premeditação" podem perturbar as operações dos princípios naturais que governam a mente, que são justamente os fenômenos que essa filosofia pretende descrever e

\footnotetext{
${ }^{31}$ Ao que tudo indica a passagem da obra de juventude para a obra madura de Hume é marcada por uma aguda sensibilidade às questões de estilo. Não parece ser casual que Hume tenha variado os gêneros de composição conforme os temas filosóficos que aborda. Exemplos disso são os Diálogos sobre a Religião Natural e os Ensaios Políticos, Morais e Literários. Cada uma dessas obras aborda temas distintos e emprega formas literárias distintas. A intenção de realizar a conciliação das duas espécies de filosofia parece estar no fundo desse esforço. Evidentemente essa análise da relação entre a forma de exposição e a doutrina pode ser estendida para além da questão do estilo. Ela pode conduzir a discussão entre o gênero adotado e a maneira de fazer filosofia. Essa discussão está, contudo, além do que nos propomos a fazer aqui.
} 
analisar $^{32}$. Para evitar, na medida do possível, esse inconveniente o filósofo humiano deverá coletar seus experimentos recorrendo à "observação cuidadosa da vida humana no curso ordinário do mundo, do comportamento dos homens em companhia, nos negócios e em seus prazeres." (TNH, p. xix)

Essa dificuldade é, diga-se de passagem, um bom sinal de que não se deve confundir a opção de Hume pelo método experimental com a mera escolha da experiência como garantia objetividade e da evidência da ciência da natureza humana. Para usarmos as palavras de Malherbe, não se trata de um empirismo "ingênuo" que pretende tirar a verdade do próprio sensível, mas de um outro empirismo que tentará responder a duas questões fundamentais: 1) "o que a experiência nos traz?"; 2)"O que é a filosofia para verificar a mente (vérifier l'esprit)?"33 Trata-se de um pensamento radical que irá investigar a própria experiência, em vez de simplesmente atribuir-lhe o papel de fiadora da evidência do sistema.

Não por acaso, tanto o Tratado quanto a Investigação tomam o exame dos elementos constituintes e dos princípios ordenadores da própria experiência como ponto de partida para a formulação da ciência da natureza humana.

\footnotetext{
32 TNH, p. xix.

${ }^{33}$ Para Malherbe essas questões estariam inscritas já na própria ciência newtoniana. Nesse sentido Hume seria radicalmente fiel à sua inspiração. Quanto a esse ponto cf. Malherbe, La philosophie empiriste de Hume, pp.39-42.
} 


\section{Capítulo II - A Composição da Experiência e o "Cimento do Universo": Impressões, Idéias e Relações Naturais.}

\section{I}

Não espanta que uma filosofia que pretende levar sua investigação até os fundamentos da própria experiência tome a análise dos dados empíricos - considerados como dados da percepção - como ponto de partida. Uma abordagem como essa é no mínimo coerente em se tratando de um pensamento que, embora fundado sobre a experiência, se recusa a atribuir ao dado experimental o papel de fiador da ciência antes de um exame prévio de seu estatuto. 0 primeiro movimento do exame humiano das percepções consiste na elaboração de duas clivagens que estabelecem uma certa "ordem" e um "arranjo", nas palavras de Hume, para "nossos objetos"34. Tratase, de modo geral, de realizar um exame de nossas percepções estabelecendo distinções entre suas várias "classes ou espécies ${ }^{35}$ ". Esse exame fornecerá um quadro geral que serve de ponto de partida para a constituição da ciência do homem, ao mesmo tempo em que estabelece condições que uma tal ciência terá cumprir.

Essa etapa da "geografia da mente" tem início, como se sabe, com a conhecida distinção entre impressões e idéias. Colocando o acento de sua análise na maneira como a mente é afetada por seus conteúdos, Hume elege duas qualidades que dizem respeito diretamente ao modo pelo qual uma percepção é sentida na mente, como critérios para diferenciar os gêneros básicos de percepção:

\footnotetext{
${ }^{34}$ Cf. TNH, p.2.

35 Os termos "classe" e "espécie" são do próprio autor Cf. Investigação, p.18. Ainda sobre o emprego termos desses termos vale ressaltar que, como procuraremos mostrar adiante, sua utilização não tem conotações de cunho ontológico.
} 
Todas as percepções da mente humana se resumem a dois gêneros distintos, aos quais eu dou o nome de impressões e idéias. A diferença entre elas consiste nos graus de força e vivacidade com que atingem a mente e abrem caminho em nosso pensamento ou consciência. ( $T N H$, p.1; grifo nosso)

Doravante, Hume chamará de idéias as percepções mais fracas e de impressões as mais fortes. Mas não é apenas do ponto de vista da força com que entram na mente que esses conteúdos se diferenciam. A essa diferença de graus de força soma-se uma outra que diz respeito à precedência de nossas impressões sobre nossas idéias.

As percepções que entram com mais força e violência podem ser chamadas de impressões; sob esse nome eu incluo todas as nossas sensações, paixões e emoções quando de sua primeira aparição à alma. Por idéias designo as imagens fracas de impressões no pensamento e raciocínio. ( $T N H$, p.1; grifo nosso)

Como faz questão de notar o próprio Hume, ressaltando o caráter originário das impressões, essa dessemelhança pode ser expressa nos termos da diferença entre "pensar" e "sentir", cuja evidência é apresentada como incontestável. Não por acaso a Investigação é por esse flanco que Hume investe para apresentar essas duas noções ao leitor.

Como todos sabem, há uma diferença considerável entre as percepções da mente quando um homem sente a dor de um calor excessivo ou o prazer de uma tepidez moderada, e quando, posteriormente, ele relembra a sensação em sua memória ou a antecipa em sua imaginação. (Investigação, p. 17).

Exposta nesses termos, a distinção entre as duas classes de percepções não põe em relevo somente a diferença entre os graus de força e vivacidade de nossas percepções. Prefigurando de certo modo a formulação do princípio do empirismo, a abertura da seção II da 
Investigação sobre o Entendimento Humano assinala um outro aspecto da diferença entre idéias e impressões, na medida em que ressalta 0 caráter originário das impressões e a natureza reflexiva das idéias ${ }^{36}$. A matriz das idéias será sempre uma impressão, ainda que possamos formar idéias, por assim dizer, secundárias como cópias de cópias. Ao optar por apresentá-la dessa forma Hume adota um modo de exposição que ressalta a precedência da impressão sobre a idéia, do sentir sobre o pensar, ou, se quisermos utilizar a terminologia de Yves Michaud, do "dado" sobre o "mental" ${ }^{37}$.A impressão é, desse ponto de vista, uma presença imediata, seja ela uma paixão que acomete o sujeito, seja ela uma sensação que o afeta. Tal presença é refletida palidamente no pensamento, seja pela imaginação, seja pela memória. A produção da idéia é, portanto, uma etapa importante na constituição da experiência, sem idéias ficaríamos restritos a impressões imediatas. É porque a mente, em certa medida, reproduz os dados fornecidos pela impressão que são constituídos tanto o sistema da memória, quanto as antecipações e as fantasias da imaginação. Note-se que as idéias da memória são mais vivas que as da imaginação e que suas seqüências reproduzem, como dirá Hume mais à frente, a "ordem" e a "posição" das impressões. Já a imaginação é livre para "transpor" e "transformar" suas idéias, mas essas não retém um grau considerável de força e vivacidade. ${ }^{38}$

\footnotetext{
${ }^{36}$ Isso não significa, porém, que o princípio do empirismo já esteja exposto aqui. A rigor nessa etapa da argumentação a precedência da impressão sobre a idéia não tem ainda estatuto de um princípio geral da ciência da natureza humana. Ela é apenas constata a partir de uma série de exemplos. Elevá-la á condição de princípio é uma outra etapa que demandará algumas outras mediações.

${ }^{37}$ Sobre isto cf. Michaud, Hume et La Fin de la Philosophie, cap. 3.

${ }^{38}$ Sobre isto cf. $T N H$, p.8: "Vemos pela experiência que quando uma determinada impressão que já esteve presente à mente reaparece nela sob a forma de uma idéia, isso pode ocorrer de duas maneiras diferentes: ou ela retém um grau considerável de sua vivacidade original, sendo algo intermediário entre uma impressão e uma idéia, ou perde inteiramente a vivacidade, tornandose uma idéia perfeita. A faculdade pela qual repetimos nossas impressões da primeira maneira chama-se memória, e a outra, imaginação."
} 
Embora expostas com uma simplicidade e economia notáveis, essas considerações acerca das diferentes espécies de percepções encobrem uma análise complexa do campo mental. Nela a ênfase do exame recai, principalmente, sobre a maneira como somos afetados por nossas percepções. A definição que citamos no início deste capítulo já indica, aliás, essa opção de análise: idéias e impressões são inicialmente distinguidas pela força com que "atingem" (strike) a mente - o que, diga-se de passagem, sugere uma concepção do pensamento que não descarta uma certa afinidade entre pensar e sentir ${ }^{39}$. O problema é que do ponto de vista dessas qualidades a dessemelhança entre idéias e impressões é, como Hume não e cansa de ressaltar, de "graus".

Em geral, a idéia não se confunde com a matriz da qual foi copiada. A força e a vivacidade das impressões e de suas cópias fornecem um índice natural ${ }^{40}$ e praticamente inequívoco de diferenciação entre essas duas classes de percepções. Tanto é assim que, como dá a entender o Tratado, a capacidade de distinguir entre essas classes de percepções poderia até mesmo servir para discernir entre a normalidade e a doença, ou a loucura.

\begin{abstract}
Os graus comuns de [força e vivacidade das impressões] são facilmente distinguíveis [daqueles das idéias], embora não seja impossível que em certos casos particulares umas se aproximem muito das outras. Assim, no sono, na febre, na loucura ou em quaisquer emoções muito violentas da alma, nossas idéias podem se aproximar de nossas impressões. ( $T N H$, p.2)
\end{abstract}

\footnotetext{
${ }^{39}$ Como dirá Hume ao determinar as causas da crença: "Assim, todo raciocínio provável não é senão uma espécie de sensação. Não é somente na poesia e na música que devemos seguir nosso gosto e sentimento, mas também na filosofia. Quando estou convencido de um princípio qualquer, é apenas uma idéia que me atinge com mais força. Se dou preferência a um conjunto de argumentos em detrimento de outro, não faço senão deliberar a partir de meu sentimento da superioridade de sua influência." (TNH, p.103)

40 Sobre a "naturalidade" da distinção entre idéias e impressões cf. Waxman, Hume's theory of consciousness, p. 29.
} 
A força e a vivacidade não fornecem um critério rígido de demarcação, mas assinalam as notas características que nos fazem distinguir naturalmente, e em circunstâncias normais, o "sentir" do "pensar". Assim, é possível confundirmos impressões e idéias, uma vez que "devido à qualquer fermentação extraordinária do sangue e dos espíritos (...) qualquer fiç̧ão ou idéia exerça sobre nós a mesma influência das impressões da memória ou das conclusões do juízo." (TNH, p.123) E não é apenas na loucura ou na febre que um homem pode confundir essas duas classes de percepção, mas, "algumas vezes nossas impressões são tão fracas e débeis que não podemos distingui-las de nossas idéias." ( $T N H$, p.2) O papel central desempenhado pela noção humiana de crença (belief) atesta a flexibilidade e os efeitos desse critério. Pois é nesse fenômeno que se pode flagrar a operação pela qual uma impressão presente, o hábito, uma relação, uma paixão, ou mesmo um discurso eloqüente, acrescenta e transfere vivacidade a uma idéia a um grau tão elevado que somos compelidos a conceder-Ihe estatuto de realidade. É verdade que, não obstante Hume mantenha no horizonte a possibilidade de indistinção entre impressões e idéias, a constatação de que essas qualidades são mais intensas na impressão é válida para a imensa maioria dos casos. Além disso, é a força de uma idéia que como mostrará o caso da crença - nos faz considerar como real uma determinada idéia. Nesse fenômeno, por um acréscimo de força e vivacidade somos levados a conferir a uma idéia o título de realidade, do mesmo modo que o fazemos quando estamos diante de uma impressão. Não parece, aliás, absurdo afirmar que é pela mesma razão (seu elevado grau de força) que não somos jamais tentados a duvidar da realidade uma impressão presente. Mesmo assim, ao contrário do que poderia parecer, essa diferença de graus não opera como fundamento de uma distinção ontológica. O campo da percepção é, nesse sentido, homogêneo. Hume é taxativo a esse respeito: "a idéia de vermelho que 
formamos no escuro e a impressão que atinge nossos olhos sob a luz do sol diferem apenas em grau, não em natureza." (TNH, p.3) O termo percepção abrange tanto as sensações e paixões quanto as idéias. Se os conteúdos dessas duas operações se distinguem é pelos graus de força e vivacidade de cada um deles, o que indica que não há, rigorosamente, diferença ontológica entre a matéria do sentir e a matéria do pensar no que tange ao modo pelo qual somos por elas afetados.

Mas ainda que, desse ponto de vista, a força e a vivacidade sejam as qualidades que permitem identificar a qual classe uma percepção pertence, essas características não esgotam as diferenças entre impressão e idéia. A relação mais geral entre impressões e idéias é a relação entre a cópia e seu original. Num empirismo estrito, como o de Hume, essa relação implica uma precedência temporal da impressão. Do contrário, seríamos obrigados a admitir que nossas idéias têm origem em algum outro lugar que não a experiência, abrindo assim, um flanco para a admissão de teses como a das idéias inatas. Conforme o que poderíamos considerar como sendo uma primeira formulação do princípio do empirismo ou da cópia no Tratado da Natureza Humana:

A primeira circunstância que salta aos olhos é a grande semelhança entre nossas impressões e nossas idéias em todos os detalhes (every particular), com exceção do grau de força e vivacidade. Idéias são, de alguma maneira, o reflexo de impressões, e assim todas as percepções da mente são duplas, aparecendo como impressões e como idéias. ( $T N H$, pp.2-3)

O problema dessa primeira exposição do princípio do empirismo é que ela contém uma generalização excessiva. Sem dúvida, é perfeitamente aceitável que a idéia que tenho de uma maçã seja um reflexo pálido das maçãs que já experimentei. Mas, como explicar que eu possua idéias de objetos que não são de forma alguma dados aos sentidos? Hume é o primeiro a admitir essa dificuldade: "eu posso 
imaginar uma cidade como Nova Jerusalém, pavimentada de ouro e com os muros cobertos de rubis, embora eu nunca tenha visto uma tal cidade." (TNH, p.3) Exemplos como esse mostram a necessidade de precisar a tese de que as impressões são as matrizes das idéias e refinar sua formulação. Embora todas as idéias tragam uma grande semelhança com as impressões, a afirmação de que todas elas são cópias exatas de impressões não é universalmente válida. A necessária depuração do princípio da cópia será alcançada através de uma outra clivagem fundamental: a divisão de nossos conteúdos mentais em simples e complexos. "Percepções ou impressões e idéias simples são aquelas que não admitem distinção nem separação. As complexas, ao contrário, podem ser distinguidas em partes." (TNH, p.2) Essa segunda clivagem é sem dúvida menos flagrante e menos "natural", por assim dizer, que aquela que separava idéias e impressões conforme os seus graus de vivacidade. A separação das qualidades unidas num objeto previamente dado aos sentidos não é o resultado imediato da mera percepção do objeto, mas de uma operação intelectual ou, para sermos mais precisos, de uma ação da imaginação ${ }^{41}$. Trata-se, portanto, de uma distinção mediada por essa faculdade.

A divisão entre simples e complexos mostra que posso isolar quaisquer qualidades sensíveis que estejam porventura unidas num mesmo objeto, decompondo-o nas várias sensações que o constituem. "Embora uma cor, um gosto e um cheiro particulares sejam qualidades unidas nessa maçã, é fácil perceber que elas não são as mesmas, mas são ao menos distinguíveis umas das outras" ( $T N H$, p.2). Essa possibilidade de decomposição dos elementos simples que constituem os objetos da sensação lança uma nova luz sobre a aplicação do princípio da cópia e permitem que Hume o enuncie da seguinte forma: "que todas

${ }^{41}$ Sobre isto cf. Waxman, Hume's Theory of Consciousness, p.42 
as nossas idéias simples são, em sua primeira aparição, derivadas de impressões simples que correspondem a elas e às quais elas correspondem exatamente." ( $T N H$, p.4) A distinção entre simples e complexos permite, portanto, determinar melhor o escopo de validade dessa proposição, restringindo-a à relação entre impressões e idéias simples $^{42}$. Essa nova divisão repousa sobre o princípio da diferença e separação, que é logicamente anterior e condicionante ao princípio da cópia $^{43}$.

Sob essa outra formulação, mais precisa, o próprio princípio do empirismo já implica a precedência das impressões simples sobre as idéias simples. O que será explicitado na prova dessa proposição em termos que, antecipando em boa medida a análise da causalidade, permitem inferir que as impressões simples são causas das idéias simples. Em primeiro lugar, constata-se uma conjunção constante entre idéias simples e impressões simples. Esse fato prova que há uma dependência entre os dois gêneros de percepção. Mas, para comprovar o princípio do empirismo, é preciso determinar "de que lado está essa dependência". A confirmação dessa inferência é fornecida pela "experiência constante", que mostrará que as "impressões simples sempre antecedem suas idéias correspondentes", e não o inverso.

Vale notar que, tendo posto o princípio do empirismo em termos mais precisos, Hume poderá então completar sua classificação das percepções e estabelecer as primeiras relações entre elas. Será possível, em primeiro lugar, explicar a diferença entre as impressões de sensação e as de reflexão e, em segundo, explicitar de que forma idéias e impressões secundárias são produzidas na mente. As impressões de

\footnotetext{
${ }^{42}$ Cf. $T N H$, p.3: "Após o exame mais apurado de que sou capaz, ouso afirmar que para cada idéia simples há uma impressão simples que a ela se assemelha, e que para cada impressão simples há uma idéia correspondente."

${ }^{43}$ Esse princípio tem diversas ocorrências no Tratado, sendo evocado sempre nos seguintes termos: "todos os objetos que são diferentes são distinguíveis, e todos os objetos que são distinguíveis são separáveis pelo pensamento e pela imaginação." (TNH, p. 18)
} 
sensação são aquelas que surgem "originalmente na alma, por causas desconhecidas", enquanto as segundas são derivadas de nossas idéias da seguinte forma:

uma impressão atinge nossos sentidos e nos faz perceber calor ou frio, sede ou fome, prazer ou dor, de uma espécie ou de outra. Uma cópia dessa impressão permanece na mente depois que ela cessa; a isto chamamos idéia. Quando retorna à alma, essa idéia de prazer ou dor produz novas impressões de desejo ou aversão, esperança ou medo, as quais podem ser apropriadamente chamadas de impressões de reflexão, pois dela derivam. Estas são novamente copiadas pela memória e pela imaginação e se tornam idéias, as quais, por seu turno, podem dar origem a outras impressões e idéias. Assim, as impressões de reflexão são antecedentes às idéias correspondentes, mas são posteriores às impressões de sensação e delas são derivadas. (TNH, p.8)

Exposta dessa forma ficam claros dois aspectos da constituição de nossas percepções. De um lado, o processo pelo qual impressões produzem idéias é ilimitado, podendo reproduzir-se por diversos, por assim dizer, espelhamentos. Por outro, fica evidente que mesmo que a causa imediata de uma impressão secundária ou de reflexão seja uma idéia, sempre haverá uma sensação no inicio da cadeia.

Idéias e impressões são distintas, portanto, sob dois aspectos fundamentais. Em primeiro lugar, trata-se de diferenciá-las a partir da oposição entre as percepções mais vivas e as mais débeis. Essa distinção, que diz respeito ao modo como o sujeito é imediatamente afetado por tais percepções, não permite estabelecer uma heterogeneidade radical entre os dois gêneros de percepção. Pelo contrário, por tratar-se de uma diferença de graus de uma mesma qualidade, ela estabelece uma homogeneidade que faz da idéia e da impressão duas categorias intercambiáveis, ao menos em princípio. Por outro lado, do ponto de vista de sua origem, idéias e impressões são gêneros totalmente distintos. Sob essa perspectiva, não há meios tons e 
nem transitividade possível entre as duas classes de percepções. 0 termo impressão refere-se sempre à matriz de onde se origina uma idéia. Em outras palavras, do ponto de vista de quem percebe, essas duas classes são diferenciadas segundo o critério da força e da vivacidade, que instaura permite descrever o campo das percepções como um território homogêneo, cujos conteúdos não são ontologicamente distintos; mas é possível distingui-las também, do ponto de vista teórico, segundo o princípio do empirismo, onde há uma diferença irredutível, no que tange à origem das percepções. Nesse último sentido uma idéia simples, como se viu, será sempre a representação ou cópia fiel de uma impressão simples correspondente, e as idéias complexas poderão, ou não, representar fielmente objetos dados empiricamente, mas sempre serão compostas a partir de impressões simples.

Mas, além disso, o fato de que as idéias complexas não necessariamente correspondem a impressões complexas leva Hume estabelecer um outro princípio fundamental da ciência da natureza humana: "a liberdade da imaginação para compor e mudar suas idéias $^{44 " .}$ Através da liberdade da imaginação, explica-se o motivo pelo qual são possíveis todas as idéias fictícias que o homem é capaz de conceber $^{45}$. A imaginação será, doravante, definida por sua capacidade "de compor, transpor aumentar ou diminuir os materiais fornecidos a nós pelos sentidos e pela experiência". Essa capacidade, porém, está longe de ser ilimitada. Por um lado, a imaginação opera sempre a partir dos dados fornecidos pela experiência; e por outro, seu escopo de atuação é restringido pelo princípio da não contradição. A idéia de uma montanha de ouro, por exemplo, é perfeitamente concebível através da junção das idéias do ouro e da montanha. A idéia de uma montanha

\footnotetext{
${ }^{44}$ Cf. TNH, p.10, Investigação, pp. 18-19.

${ }^{45}$ Cf. $T N H$, p. 10.
} 
sem vale, no entanto, nós não poderemos jamais conceber, pois a imaginação não é capaz de formar idéias que impliquem em contradição. ${ }^{46}$ Dentro desses limites a imaginação é uma faculdade absolutamente livre. As operações da imaginação, bem como seus produtos, são explicadas em contraposição ao funcionamento da memória. Enquanto a primeira é livre para criar idéias fictícias, a segunda procede sempre reproduzindo a ordem e a forma sob as quais as impressões originais se apresentam ao espírito. Por se apresentarem sob a mesma forma que as impressões, as idéias da memória adquirem maior força e vivacidade que as idéias da imaginação. ${ }^{47}$

\section{II}

Qual é, então, a novidade trazida pela análise humiana da percepção? Para contemporâneos de Hume como Thomas Reid, e outros autores da filosofia do senso comum, a rigor, nenhuma. Para esses pensadores, o Tratado da Natureza Humana não foi senão o ponto culminante de uma seqüência de erros que pôs o pensamento moderno a perder. $O$ equívoco inaugural dessa série se localizaria no cogito e na análise cartesiana mente. De erro em erro, passando por Locke e Malebranche, chegar-se-ia aos sistemas de Berkeley e Hume.

Para evitar o ceticismo, o bispo de Cloyne, cheio de boas intenções, teria sido conduzido paradoxalmente a negar a existência da matéria. Mais inconseqüente, o autor do Tratado, por sua vez, teria levado o absurdo a seu ponto máximo, negando não só a existência dos objetos externos, como a do próprio sujeito ${ }^{48}$. O "monstro" do

\footnotetext{
${ }^{46}$ Cf. Investigação, p. 18.

47 Sobre isto cf. TNH, p. 9.

${ }^{48} \mathrm{Cf}$. Reid, An Inquiry into the Human Mind into the Principles of the Common Sense, VII, p. 10: "Descartes no sooner began to dig in this mine, then scepticism was ready to break upon him. He did what he could to shut it out. Malebranche and Locke, who dug deeper, found the difficulty of keeping out this enemy still to encrease; but they laboured honestly in the design. Then Berkeley, who carried on the work, despairing of securing all, bethought himself: By giving up the material world, that he thought might be spared without a loss, and even with advantage, he
} 
ceticismo, na expressão de Reid, estaria sendo gestado desde o advento da filosofia de Descartes e seu longo trabalho de parto se consumaria com a publicação do Tratado da Natureza Humana.

Por isso, é contra a "way of ideas" que Reid aponta suas armas. O germe do erro estaria na problematização da percepção inerente à "way of ideas" - uma certa herança tributária do equívoco cartesiano que interpõe uma representação (a idéia) entre o sujeito e o objeto do conhecimento. Doravante, estaria dada a ocasião para que os "devotos dessa filosofia, a partir de um preconceito natural a seu favor, esforçassem-se para estender sua jurisdição para além de seus justos limites, colocando sob seu foro os ditames do Senso Comum" (Reid, Inquiry, p.7) Não só Malebranche, mas Locke, Berkeley e Hume seriam, estritamente nessa medida, simples continuadores do erro de Descartes. Berkeley e, sobretudo, Hume não seriam mais do que autores que desenvolveram ao limite às conseqüências do que hoje chamaríamos de filosofia da representação, conduzindo à ruína das ciências e minando toda evidência do senso comum. Desse ponto de vista, em vez de filosofia original, o pensamento humiano não passaria de um cartesianismo levado ao absurdo.

Essa leitura, diga-se de passagem, se assemelha em alguma medida a uma outra bastante comum, segundo a qual Hume seria um herdeiro radical de Locke e Berkeley. Nessa chave de leitura seções do Tratado como a do ceticismo sobre os objetos dos sentidos seriam meramente o resultado de um desenvolvimento lógico das teses empiristas, conduzidas a seus limites mais extremos. O mérito de Hume, segundo os defensores dessa interpretação, residiria, sobretudo, em seu rigor ao desdobrar as teses empiristas.

hoped, by an impregnable partition, to secure the world of spirits. But, alas! the 'Treatise of Human Nature' wantonly sapped the foundation of this partition, and drowned all in universal deluge." 
Nessas duas leituras trata-se de comentar a filosofia humiana como ponto extremo de uma tradição da qual ele mesmo, porém, acreditava estar se distanciando. Ambas as interpretações suscitam suspeitas, para dizer o mínimo. Afinal, há uma grande diferença entre a novidade reivindicada por Hume e o mérito, ou demérito (conforme a preferência ideológica do comentador), de extrair com rigor todas as conseqüências de um quadro conceitual previamente dado.

Ora, não é trivial começar a geografia da mente pelas duas clivagens que marcam o início do Tratado e da Investigação. Ao menos nos termos em que Hume a expõe, dificilmente se poderia incluir a distinção entre impressão e idéia entre as diversas formulações que servirão para a articulação das teses da filosofia da representação ou do empirismo clássico. Se para essas duas escolas a análise nossos conteúdos mentais leva necessariamente à tese de que há realidades externas representadas de alguma forma por nossas idéias, para Hume as noções de idéia e de impressão não nos permitem inferir qualquer existência externa.

É verdade que nas linhas iniciais do Tratado, Hume parece retomar, em outros termos e através da introdução do critério da força e da vivacidade, as noções lockianas de idéias de sensação e de reflexão. Mas, enquanto é possível pensar que para Locke uma idéia de sensação me indica um objeto externo que é sua causa, para Hume a impressão não se remete a uma exterioridade. Em Locke, aliás, o termo "impressão" por vezes serve ao autor para sugerir a passividade da mente humana ao receber as idéias de sensação derivadas dos corpos. Embora conhecer esses objetos esteja além do alcance do entendimento humano, as impressões podem denotar que há substâncias corpóreas ou materiais e que nelas reside a origem das idéias de sensação. No que concerne às idéias simples de sensação Locke parece ir ainda mais longe numa direção que, vale ressaltar, será veementemente recusada por 
Hume. Para o empirista inglês, essas idéias são fornecidas à mente pelos sentidos e são nela produzidas pelas coisas em si mesmas (things in themselves). ${ }^{49}$

$\mathrm{Na}$ tentativa de marcar com precisão a diferença entre os dois filósofos reportemo-nos à distinção entre qualidades primárias e secundárias e ao estatuto das idéias relativas a cada uma delas em Locke. Note-se, em primeiro lugar, que o empirista inglês distingue com precisão o sentido dos termos idéias e qualidade. Por idéia o filósofo entende toda percepção da mente, por qualidade o poder dos objetos de produzi-las na mente ${ }^{50}$. Todas as idéias simples são percepções de cor, sabor, odor, forma, solidez e movimento - qualidades que, num primeiro momento, atribuímos integralmente aos objetos externos que compõem a experiência. Uma análise mais acurada, no entanto, irá mostrar que nem todas elas encontram-se de fato presentes nos corpos. Há qualidades indissociáveis dos corpos (solidez, extensão, figura e mobilidade), em qualquer estado em que se encontrem e a despeito de quaisquer mudanças que sofram.

Tome um grão de trigo e divida-o em duas partes: cada parte continua a ter solidez, extensão, figura e mobilidade; divida-o de novo, e ele continua a reter as mesmas qualidades. Continue a dividi-lo até que as partes se tornem insensíveis: cada uma delas ainda retém todas essas qualidades. (Ensaio sobre o Entendimento Humano, p. 135)

Essa impossibilidade de que haja corpos destituídos de solidez, figura, extensão e mobilidade, que Ihes confere um estatuto específico e leva à constatação de que essas são qualidades "originais" ou "primárias".

\footnotetext{
${ }^{49}$ Cf. Locke, Ensaio sobre o Entendimento Humano, p. 160. Citamos segundo a edição Nidditch. Oxford University Press, 1978.

${ }^{50}$ Cf. Locke, Ensaio sobre o Entendimento Humano, p. 134.
} 
Diferentemente, há uma outra classe de qualidades (as cores, os cheiros, os gostos, os sons, entre outros), que são inteiramente relativas as condições da percepção.

Consideremos as cores vermelha e branca no pórfiro. Impeça a luz de atingi-lo e suas cores desaparecem, ele não produz mais qualquer idéia em nós. Se retorna a luz, ele volta a produzir em nós essas aparições. Poderia alguém pensar que a presença ou ausência de luz produz quaisquer alterações reais no pórfiro e que as idéias como as de brancura ou vermelhidão estão realmente nele, à luz, quando é evidente (plain) que no escuro ele não tem cor alguma? (Ensaio, p. 138)

A incidência ou não de luz, como no exemplo, é capaz de alterar a percepção de um objeto. Sem luz suficiente, não veremos suas cores. Essa mudança não equivale, contudo, a nenhuma transformação real do objeto. No que concerne às qualidades primárias o caso é bem diferente. Pois, como mostra o argumento que expusemos acima, longe de serem subjetivas, elas devem estar presentes em todo objeto, a despeito de quaisquer alterações que ele venha a sofrer. $E$ essa precedência das qualidades primárias sobre as secundárias vai determinar a resposta de Locke para a questão da produção das segundas. Se percebemos qualidades secundárias, isso ocorre em virtude da ação das qualidades primárias das partículas mais elementares dos corpos ${ }^{51}$.

Essa diferença de estatuto entre dois gêneros de qualidades espelha-se nos diferentes caracteres que Locke vai conferir às idéias que as representam. Aquelas que dizem respeito a qualidades primárias de algum modo assemelham-se ao objeto a que se referem e, mais que isso, seus "padrões existem realmente nos corpos em si mesmos 52 ". o

\footnotetext{
${ }^{51}$ Para uma explicação mais detalhada desse ponto, cf. François Duchesneau, John Locke, In: História da Filosofia, vol. IV, François Châtelet (org.) Rio de Janeiro, Zahar, 1974, pp. 25-26.

52 Cf. Locke, Ensaio sobre o Entendimento Humano, p. 136.
} 
mesmo não se pode afirmar das idéias de qualidades secundárias, que não têm nenhuma semelhança com seus objetos. Ainda assim, elas são provas de que esses objetos possuem um poder de produzir sensações em nós. $E$, por isso mesmo, embora não possam ser consideradas como correspondentes a qualidades realmente existentes nos corpos, tais idéias não deixam de ser consideradas como reais, na medida em que são "efeitos dos poderes das coisas, sem nosso concurso, ordenados por nosso Autor ${ }^{53 \prime}$, para que possamos distinguir os vários objetos.

Desse modo, ainda que Locke negue uma correspondência estrita entre as idéias e as coisas, sua filosofia abre a possibilidade de um certo materialismo e não deixa de afirmar que nossas representações foram misericordiosamente dispostas pela divindade para nossa orientação no mundo ${ }^{54}$. Assim, de maneira um tanto inesperada o empirismo de Locke parece manter algo da filosofia da representação, apesar de recusar direito de cidadania às idéias inatas de Descartes. Mesmo sem elas, abre-se espaço para pensar alguma relação entre representação e objeto, e a benevolência divina assegura que deve haver algum grau de adequação entre as coisas e as idéias, ainda que a correspondência exata entre esses termos seja considerada problemática e indeterminável. Ou seja, bem ou mal, as idéias de sensação permanecem como correlatos, ainda que bastante precários, de objetos externos. E nesse ponto, consideradas as diferenças, Locke parece preservar, à sua maneira e em seus termos, a tese cartesiana segundo a qual "o sentido externo é posto em movimento pelo objeto55". Aparentemente, ao menos, não é por acaso, em Locke, o termo

\footnotetext{
53 Cf. Locke, Ensaio sobre o Entendimento Humano, p. 334.

${ }^{54}$ Vale notar que para explicar a produção das idéias de sensação Locke será obrigado a admitir a validade da teoria que postula um estrato corpuscular subjacente às percepções sensíveis. Cf. Duchesneau, op. cit.

${ }^{55} \mathrm{Cf}$. Descartes, Regras para a Direção do Espírito, regra XII, p. 68.
} 
impressão servirá para exprimir a produção das idéias sensação pelos objetos externos. Quanto a esse ponto, vital para aferir a distância que separa Locke de Hume, vale lembrar a observação de John Yolton:

Sabemos que o conceito que Locke faz de corpo (objeto físico, substância material) considera os corpos como tendo uma estrutura corpuscular insensível, estrutura que ele concebia (quanto a suas partículas) como dotada do poder de afetar outros objetos e aqueles que os percebem. Ora, essa componente do conceito de corpo não deriva da experiência e da observação, mas vem da teoria, então corrente e empregada por muitos cientistas da época como Boyle e Newton. (Realism and Appearences, p. 68)

No empirismo de Locke é através desses corpúsculos insensíveis que são explicados, em última instância, tanto o movimento dos objetos quanto o poder que eles têm de afetar os sentidos e produzir idéias de sensação. ${ }^{56}$

Assim, no que concerne à filosofia de John Locke, a censura de Reid talvez não deixe de fazer algum sentido. No que tange a Hume, porém, o caso é bem diferente. A análise humiana da percepção não leva à postulação de uma dualidade entre objeto e sensação. Pelo contrário, em nota do Tratado, numa referência nominal a Locke, o filósofo escocês fará questão de ressaltar que ao empregar os termos "idéia" e "impressão", ele o faz de maneira diversa - restituindo à idéia o sentido original que a filosofia lockiana ${ }^{57}$ estendeu indevidamente a todas as percepções. Na mesma nota, no que concerne às impressões, a afirmação de Hume o distancia ainda mais do empirista inglês, na medida em que esse termo não se remete mais ao modo de produção dessas percepções.

\footnotetext{
${ }^{56}$ Cf. John Yolton, Realism and Appearences, p. 69.

57 Sobre isso cf. a passagem completa em $T N H$, p.2, nota1.
} 
Pelo termo impressão eu gostaria que se entendesse aqui não a expressão da maneira em que as percepções mais vivas são produzidas na alma mas meramente as percepções elas mesmas, para as quais não há um nome particular em inglês ou em qualquer outra língua que eu conheça. ( $T N H$, p.2, nota)

A rigor, a origem das impressões é assunto inacessível ao homem. Sob a perspectiva fenomenista que Hume adota em sua análise da percepção esse tema extrapola os limites da experiência efetiva e está, de antemão, excluído da investigação.

O ponto de vista fenomenista adotado por Hume interdita, portanto, a afirmação de que haja algo nas percepções que possa legitimar a concepção de uma dupla existência. Como dirá o autor, ao discutir o ceticismo quanto aos sentidos:

Que nossos sentidos não oferecem impressões como imagens de algo distinto ou independente e externo, é evidente. Pois o que eles nos transmitem não é senão uma percepção singular, sem jamais nos dar a menor indicação de algo para além dela. (TNH, p.189)

Sem dúvida, pode-se perceber aqui outra conseqüência da adoção do princípio da diferença e da separação, cuja operação já notamos ao falarmos da divisão de nossas percepções em simples e complexas e ao qual voltaremos mais adiante. Afinal, consideradas nelas mesmas, nossas percepções originais, as impressões, não se remetem a nada delas distinto. Ao adotar o princípio da diferença e da separação, que observamos no caso da divisão das percepções em simples e complexas, Hume elimina a possibilidade de que qualquer percepção nos remeta a algo dela distinto. Para Hume, a impressão é o próprio dado sensível e o limite de qualquer análise empirista que se preze. As impressões não 
são representações ou imagens de um corpo material, mas o ponto extremo a que pode chegar uma filosofia empirista.

Por isso, quando na filosofia de Hume as idéias são ditas "reflexos", "cópias" e "representações" que correspondem a impressões, elas o são num sentido distinto daquele empregado pela maioria dos filósofos modernos. Entre idéias e impressões, como vimos, não há distinção ontológica. A diferença entre ambos é que as primeiras são percepções fortes e vivas e as segundas fracas. Mas, como procuramos ressaltar ao examinarmos o princípio do empirismo, além dessa homogeneidade ontológica há uma prioridade, ou antecedência da impressão sobre a idéia. A impressão, sobretudo, a de sensação, é o dado originário, sem nenhum precedente. E nada nos indica de direito a existência de uma realidade que, de fato, estaria aquém de nossas impressões esperando o trabalho do filósofo para ser desvelada até aonde for possível. A idéia, ao contrário é a repetição dessa percepção na imaginação ou na memória. Da impressão ela em nada difere, a não ser pela intensidade de sua força. É apenas nesse sentido que a idéia pode ser designada como representação, pois ela corresponde e reproduz no pensamento aquilo que foi imediatamente dado na sensação ${ }^{58}$.

Ao deslizar o limite da análise para a impressão, sem qualquer referência a uma exterioridade, Hume rompe integralmente com a filosofia da representação. Ao contrário do que parece ocorrer no empirismo de Locke, não resta aqui nem mesmo aquela remissão da sensação a um objeto que, embora indeterminável, é considerado como causa de nossas representações. Após esse deslocamento a idéia de uma dupla existência, que está na base da filosofia da representação,

\footnotetext{
${ }^{58}$ Evidentemente que essa afirmação vale irrestritamente apenas para as idéias simples, uma vez que a imaginação é capaz de combiná-las de forma a criar ficções. Mesmo assim, essa correspondência é estrita para todos os componentes simples de todas as idéias.
} 
adquire um outro estatuto ${ }^{59}$. Doravante, não fará sentido nem opor ser e aparência, nem buscar uma via para retraçar as relações entre ambos, como pretendem os metafísicos. Esses dois termos coincidem na noção humiana de impressão que, uma vez posta diante da mente, será duplicada dando origem a uma idéia correspondente. E se a filosofia opera uma separação entre as percepções e os objetos, estabelecendo um dualismo entre objeto e imagem ou representação isso não ocorre devido à nenhuma evidência sensível, mas a uma inferência fantasiosa. Em vez de servir de caução para uma teoria do conhecimento, a idéia de dupla existência será agora o resultado de inferência que ultrapassa os limites da experiência; um gênero de ilusão, cujas causas devem ser rastreadas pela ciência da natureza humana ${ }^{60}$.

Não é, contudo, apenas no que concerne à tese da dupla existência que Hume se distancia da tradição moderna. Se através da noção de impressão a filosofia humiana desfere um golpe duro contra a idéia de dupla existência, com a divisão das percepções nas categorias de simples e complexo inicia-se um movimento que implica a impossibilidade da instituição de uma mathesis universalis. Ainda que seja introduzida no texto do Tratado de maneira aparentemente um tanto abrupta e esteja apenas subentendida na Investigação essa distinção não é nem apressada, nem injustificada, como pretendem alguns comentadores ${ }^{61}$. A decomposição das percepções complexas em percepções simples indica, em primeiro lugar, um limite da análise empirista. Ao analisar uma percepção como a da maçã, para nos atermos ao exemplo utilizado por Hume, posso dividi-la em elementos como a cor, a forma e o sabor, os quais são, por sua vez irredutíveis a uma nova análise.

\footnotetext{
${ }^{59} \mathrm{Cf}$. Deleuze, Empirisme et subjectivité, pp.13-14.

${ }^{60}$ Sobre isso cf. $T N H$, p. 189: "Uma percepção singular jamais poderia produzir a idéia de uma dupla existência a não ser através de alguma inferência da razão ou da imaginação."

${ }^{61}$ Cf. por exemplo, Anette Baier, A Progress of Sentiments, p. 34.
} 
Mas, além disso, como indica corretamente Wayne Waxman, ${ }^{62}$ a noção de simplicidade está implícita no princípio da diferença e separação que, não obstante esteja pressuposto na análise humiana da percepção desde o seu início, só será explicitado pelo autor bem mais adiante no texto do Tratado sob a seguinte formulação: "Quaisquer objetos que sejam diferentes são distinguíveis: e quaisquer objetos que são distinguíveis são separáveis pelo pensamento e pela imaginação." (TNH, p.18) Operando a distinção entre simples e complexo esse princípio, que é fundamental para a constituição de boa parte da doutrina de Hume ${ }^{63}$, determina um aspecto essencial de sua concepção da experiência e é fundamental para a problematização da causalidade. A aplicação de tal princípio às percepções complexas não aponta somente um elemento irredutível ao exame das percepções. Ela implica, também, que idéias e impressões complexas são formadas por elementos distintos que não são unidos por relações essenciais uns com os outros.

Retomemos a análise da maçã. Ali, Hume mostra, em primeiro lugar, como essa percepção complexa pode ser dividida: "embora uma cor, um sabor e um perfume peculiar sejam qualidades unidas na maçã, é fácil perceber que elas não são um mesmo, mas se distinguem pelo menos umas das outras." ( $T N H$, p.2) É porque as qualidades não se confundem que elas são separáveis e podem ser isoladas umas das outras pela imaginação. Essa separabilidade é, aliás, o fundamento no qual repousa a liberdade da imaginação, o segundo princípio da ciência da natureza humana. É porque as percepções complexas são formadas por elementos simples, distintos uns dos outros, que essa faculdade será capaz, para Hume, de compor, transpor e dividir idéias livremente,

\footnotetext{
${ }^{62}$ Cf. Waxman, Hume's Theory of Consciousness, 1,1, pp. 42-44.

${ }^{63}$ Numa lista que não se pretende exaustiva poderíamos dizer que o princípio da diferença e da separação desempenha um papel fundamental na análise de substância, abstração e causalidade. Abordaremos alguns desses temas mais adiante.
} 
limitada apenas pelo princípio de não contradição. Mas, de onde vem essa relação entre diferença e separação que implica, simultaneamente, a liberdade da imaginação e a decomposição das percepções em átomos de percepção?

A associação entre diferença e separação não é gratuita. Ela repousa sobre uma concepção singular e muito bem determinada da diferença:

Poder-se-ia naturalmente esperar que eu unisse (join) às outras relações aquela da diferença. Mas eu a considero antes como a negação de uma relação do que como algo real e positivo. Há duas espécies de diferença, enquanto oposta a identidade ou a semelhança. A primeira é chamada diferença de número, a segunda de gênero. ( $T N H$, p.6)

Ora, que esse texto nos mostra acerca da noção humiana de diferença? Antes de tudo, que a diferença pode ser de duas espécies. Uma delas diz respeito aos diversos gêneros, nos quais todo objeto pode ser considerado e classificado em razão de suas similaridades com outros objetos. Nesse caso, preserva-se alguma semelhança das qualidades das quais são dotados aqueles que pertencem a um mesmo grupo. Mas há uma segunda forma de diferenciação, mais abrangente, que distingue irrestritamente todos os objetos uns dos outros. Pela diferença de número não há dois seres idênticos entre si. Sob esse ponto de vista, só há particulares e, na medida em que a diferença é a negação de uma relação, eles são todos separáveis uns dos outros pela imaginação. Assim, glosando a análise da percepção da maçã, poderíamos dizer que a classe das maçãs distingue-se das outras frutas. Mas cada maçã é numericamente diferente de seus congêneres. $E$, no limite, a percepção que tenho desses objetos é formada por conteúdos distintos, independentes uns dos outros e sem qualquer relação essencial entre si. 
A adoção do princípio da diferença e da separação implica afirmar que as percepções complexas são decomponíveis em percepções simples e em negar qualquer relação intrínseca entre as partes que as compõem. Isso não quer dizer, evidentemente, que quando um determinado objeto me é dado aos sentidos percebo um amálgama de qualidades separadas, mas apenas que, do modo como me são dadas, nada me indica que elas possuam um "princípio de união" e nada me autoriza a afirmar que elas repousem sob "algo desconhecido", como dirá Hume ao analisar o conceito de substância. Essa noção (substância) não nos é dada nem por uma impressão de sensação, nem por uma impressão de reflexão. Na verdade, dirá Hume:

A idéia de substância, assim como aquela de modo, não é senão uma coleção de idéias simples unidas pela imaginação com um nome particular atribuído a elas, pelo qual somos aptos a evocar (recall), seja para nós mesmos, seja para os outros, aquela coleção precisa. $(T N H, \text { p.17 })^{64}$

A redução das idéias e impressões a átomos de percepção é um dos limites aos quais somos levados pela aplicação do princípio da diferença e da separação. A descontinuidade entre os elementos que compõem uma percepção complexa se reproduz de certa maneira nas séries empiricamente observáveis. Se não há relação essencial determinável entre as partes que compõem uma idéia ou impressão singular, tampouco há uma ligação de mesmo gênero quando se trata de considerar as relações entre as idéias e as impressões que elas copiam. A experiência é uma sucessão de percepções distintas entre si.

\footnotetext{
${ }^{64}$ Vale notar que esse argumento é retomado quando Hume aborda a imaterialidade da alma. Cf. $T N H$, p. 233: "O que quer que concebamos com clareza, pode existir; e o que quer que seja concebido claramente de uma certa maneira, deve existir dessa mesma maneira. Assim também, tudo o que é diferente é distinguível, e tudo que é distinguível é separável pela imaginação. Esse é um outro princípio. Minha conclusão a partir de ambos é que como todas as nossas percepções são diferentes umas das outras e de tudo o mais no universo, elas são distintas e separáveis e devem ser consideradas como separadamente existentes e devem existir separadamente sem a necessidade de outra coisa para dar suporte à sua existência."
} 
Ela não forma uma totalidade contínua, e sim um fluxo de conteúdos independentes uns dos outros. ${ }^{65}$

Não é exagerado dizer que, em Hume, a diferença opera como princípio ontológico. Como afirma Deleuze, esse princípio é anterior ao princípio da cópia, do ponto de vista daquilo que se poderia chamar de "ordem das razões" da filosofia humiana, embora lhe seja posterior no que concerne ao que poderíamos chamar de ordem "natural" ou "empírica". Nas palavras do comentador francês:

O empirismo parte desta experiência de uma coleção, de uma sucessão constante de percepções distintas. E parte delas na medida em que são distintas, independentes. Com efeito, o princípio constitutivo que dá à experiência um estatuto não é, de modo algum, "toda idéia deriva de uma impressão", cujo sentido é apenas regulador, mas "tudo o que é separável é discernível, e tudo o que é discernível é diferente." Tal é o princípio da diferença. (Empirisme et Subjectivité, p. 93)

É esse princípio que determina, em última instância, a distinção entre idéias e impressões simples e complexas, e estabelece a ausência de ligações intrínsecas entre esses conteúdos, forjando o que poderíamos chamar, empregando a expressão utilizada por Lebrun, de "ontologia da descontinuidade integral". ${ }^{66}$ Uma ontologia bastante econômica, que definirá a análise humiana de temas e conceitos fundamentais para a tradição, como no caso das noções de substância e de abstração. ${ }^{67}$

É difícil ver nessa concepção da experiência alguma afinidade com o cartesianismo, como queria Reid. Descrito dessa maneira, o mundo

\footnotetext{
${ }^{65}$ Daí, em parte, a comparação da mente com um "teatro onde diversas percepções fazem sua aparição sucessivamente; passam, repassam e se misturam numa infinita variedade de posições e situações." (TNH, p.253)

${ }^{66}$ Vale notar que a expressão é utilizada por Lebrun de forma irônica, tendo em vista a leitura fenomenológica de Hume. Cf. Hume no Álbum de Família de Husserl, in.: A Filosofia e sua História, p. 269.

67 Não por acaso, a conexão de causa e efeito é posta por Hume como algo problemático. Afinal, como o filósofo escocês não deixará de ressaltar em diversos momentos de sua obra, o "efeito é totalmente diferente da causa e não pode nunca ser nela descoberto."
} 
não oferece abrigo para a idéia de mathesis universalis, pois nele todas as relações são necessariamente exteriores a seus termos. E se não há ligações essenciais entre os conteúdos empíricos, não há lugar para pensar a existência de um logos costurando a experiência e conferindoIhe unidade e inteligibilidade intrínsecas. Sob esse aspecto, o contraste entre a filosofia humiana e o pensamento de matriz cartesiana é flagrante. Tomando os objetos da experiência sob a perspectiva humiana não é viável postular um modelo de conhecimento demonstrativo dos fatos que, como o cartesiano, pressuponha relações necessárias entre as várias "naturezas simples" que formam os $\operatorname{compostos}^{68}$. Na filosofia humiana não será lícito opor, como fazia Descartes, conjunções necessárias e conjunções contingentes entre os elementos que formam os objetos da experiência ${ }^{69}$. Pois, se não há mais ligações internas conectando os objetos, não é legítimo afirmar que haja outras relações que não as que um filósofo cartesiano qualificaria como contingentes.

E, a partir daí, como fazer coro com Descartes, quando ele afirma que "toda ciência humana consiste apenas em ver como estas naturezas simples concorrem em conjunto para a composição das outras coisas ${ }^{70 " ?}$ Em Hume, o conhecimento dos objetos da experiência não mais consistirá na recuperação das relações internas entre os elementos simples, através da transposição dos procedimentos da análise e da demonstração matemática ${ }^{71}$ ao domínio dos $\operatorname{corpos}^{72}$. Tal movimento

\footnotetext{
${ }^{68}$ Sobre isso, cf. Descartes, Regras para a Direção do Espírito, regra XII, p. 78: "Mas está em nosso poder evitar este erro, a saber, nunca ligarmos coisas entre si sem ver por intuição que a ligação de uma com a outra é completamente necessária, como acontece ao deduzirmos que nada pode ser figurado sem ser extenso, pelo fato da figura ter uma ligação necessária com a extensão e etc."

${ }^{69}$ Sobre isso, cf. Descartes, Regras para a Direção do Espírito, regra XII, p. 74: "Dizemos, em quarto lugar, que a conjunção dessas coisas simples entre si é necessária ou contingente."

70 Cf. Regras para a Direção do Espírito, regra XII, p. 79.

${ }^{71}$ Sobre a inspiração declaradamente matemática do método de Descartes Cf. Regras para a Direção do Espírito, regra IV.

${ }^{72} \mathrm{O}$ ato de refazer as ligações necessárias entre as naturezas simples é complicado e envolve três momentos fundamentais, iniciando-se pela análise dos compostos que deve revelar os seus
} 
implicaria duas alternativas igualmente recusadas pela filosofia de Hume: ou seria necessário admitir a possibilidade de que, assim como ocorre nos objetos matemáticos, houvesse relações necessárias entre os termos simples que compõem os objetos da experiência, ou levaria a desqualificação integral do conhecimento desses objetos.

Também, quanto a este ponto vale ressaltar a diferença entre o pensamento humiano e a filosofia de Locke. Pois, não obstante o pensador inglês recuse direito de cidadania às idéias inatas de Descartes e localize o fundamento de nossas da ciência nos dados dos sentidos, sua filosofia se mantém partidária de uma concepção marcadamente racionalista do conhecimento, para a qual o conhecimento strictu sensu é derivado da demonstração, cuja certeza sempre será superior à verossimilhança da probabilidade. Ante essa clivagem algumas ciências serão facilmente agraciadas com o título de conhecimento. As matemáticas, a lógica e, em grau maior, a moral, o direito e a política poderiam ser, sem maiores problemas, incluídas nesse grupo. Mas, justamente aquelas disciplinas que tratam dos fenômenos naturais, da realidade física e das propriedades dos corpos se veriam relegadas à condição de saberes meramente prováveis, e incertos - conclusão que para um admirador confesso de Newton, como Hume, seria inadmissível.

Como é possível, portanto, enquadrar Hume numa suposta escola filosófica que vai de Descartes a Berkeley, como queria Reid? Não espanta que, em carta a Hugh Blair, Hume expressasse, sem nenhuma preocupação em ser sutil, sua impaciência para com o professor de Glasgow: "eu gostaria que as pessoas se limitassem à sua velha ocupação de incomodarem-se umas às outras e deixassem os filósofos

elementos simples cognoscíveis pela intuição, passando pela síntese destes últimos novamente em compostos e terminando pela verificação de todo o processo, que visa conferir se não houve omissão de termos na análise e na síntese. Quanto a este esquema resumido do método de Descartes Cf. Lívio Teixeira, Ensaio Sobre a Moral de Descartes, pp.24-26. 
discutirem com temperança (temper), moderação e bons modos". ${ }^{73} \mathrm{~A}$ irritação de Hume parece mais que justificada. Ao incluir Descartes na genealogia da filosofia humiana e fazer de Hume um Locke que, de tão coerente nos erros da "way of ideas", foi levado ao ceticismo, Reid não percebe que, desde o início, a ciência da natureza humana recusa tanto a filosofia da representação e o que dela resta no empirismo clássico, quanto o ideal racionalista de mathesis universalis. Ao fixar o limite da análise na impressão, Hume veta que o discurso filosófico refira-se dogmaticamente a qualquer ser supostamente subjacente à percepção. Ao admitir o princípio da diferença e da separação como pressuposto ontológico de sua filosofia e levá-lo às últimas conseqüências, o pensamento humiano estabelece uma absoluta descontinuidade entre os seres, impossibilitando a postulação racionalista de um logos unificador da experiência, inscrito nos próprios objetos empíricos.

\section{III}

Mas, se essa configuração do campo experimental elimina inconvenientes tanto do racionalismo aparentado a Descartes quanto do empirismo de Locke, ela coloca um problema: é preciso explicar como se dá articulação dos objetos desse domínio. A solução dessa questão é ao mesmo tempo parte da ciência do homem e condição para sua constituição. Pois se trata de explicar de que modo somos capazes de produzir inferências e juízos acerca da verdade e da falsidade de nossas idéias, quando elas não têm nenhuma relação essencial entre si. Não é exagero dizer que a própria possibilidade de qualquer ciência, bem como seu feitio repousam sobre a capacidade de resolver essa questão em termos coerentes com as conseqüências da análise da percepção e dos pressupostos ontológicos assumidos por Hume. A descontinuidade total

\footnotetext{
${ }^{73}$ Wood, P.B., David Hume on Thomas Reid's Inquiry into Human Mind and the Principles of Common Sense: A New Letter to Hugh Blair from July 1762, In: Mind, 1986, pp.411-416.
} 
entre os conteúdos da experiência, a impossibilidade de uma correspondência estrita entre percepções e objetos, e a liberdade da imaginação demandam que a resposta a essa questão, em certo sentido clássica, receba uma nova elaboração.

Nessa medida o associacionismo assume um lugar fundamental na filosofia humiana. É pela determinação dos princípios que regram a associação de idéias que Hume pode explicar que o dado empírico se apresente como algo organizado, apesar de ser decomponível em elementos simples, individuais e distintos uns dos outros. São os três princípios de associação ou relações naturais ${ }^{74}$ que conferem regularidade e constância à ação da imaginação ${ }^{75}$, explicando a mecânica que confere alguma estabilidade e ordem a nossos pensamentos. Pela ação da semelhança, contigüidade e causalidade ${ }^{76}$ essa faculdade é levada a ligar idéias distintas e a passar naturalmente de uma idéia à outra. As relações naturais, na medida em que agem sobre a imaginação, fornecem coerência e regularidade aos dados imediatos dos sentidos e às idéias da memória. Conforme o texto do Resumo do Tratado:

Será fácil conceber a vasta conseqüência destes princípios para a ciência $d a$ natureza humana se considerarmos que, no que concerne à mente, eles são o único elo que liga as partes do universo ou nos conecta a qualquer pessoa ou objeto exterior a nós mesmos. (Resumo, p. 662)

\footnotetext{
74 É preciso lembrar que Hume distingue dois sentidos possíveis do termo relação: o primeiro designa os princípios associativos - é o que o autor denomina relação natural -, o segundo se refere a uma comparação entre duas idéias, comparação esta que é considerada apropriada pelo entendimento, e não meramente pelo jogo da imaginação e dos princípios de associação. A este segundo sentido de relação o autor dá o nome de relações filosóficas. Quanto a este tópico, Cf. TNH, pp.13-15.

${ }^{75}$ Contudo, não se deve deixar observar que, apesar de sua ação reguladora, os princípios de associação não são, de modo algum, infalíveis. No Tratado, Hume os descreve como "forças gentis" (gentle forces) que não eliminam a liberdade da imaginação, embora normalmente prevaleçam sobre ela.

76 Sobre a descrição detalhada da ação de cada um desses princípios cf. TNH, pp.11-12; Investigação, 3, pp. 23-24.
} 
Sua ação, como sugere a terminologia utilizada por Hume, é análoga à da força da gravidade na física newtoniana. As relações naturais geram uma espécie de "atração" entre os conteúdos do espírito tornando regular e coerente a sucessão das idéias complexas na imaginação. Essa atração entre os conteúdos unidos pela imaginação está profundamente ligada à idéia de uma transição fácil de uma percepção à outra. O movimento quase que ininterrupto de uma impressão ou idéia em direção a uma outra é da própria natureza humana: "é impossível para a mente se ater fixamente a uma idéia por um período considerável de tempo, e nem os seus maiores esforços poderiam levá-la a uma constância como essa." (TNH, p.283) As relações naturais agirão sobre a imaginação como elementos facilitadores dessa transição. Os princípios de associação fixam e estabelecem relações entre idéias tornando mais fácil e natural a passagem de uma à outra. Por isso,

por mutáveis que sejam, nossos pensamentos não são inteiramente destituídos de regra e método em suas mudanças. A regra pela qual eles procedem é a de passar de um objeto para aquele que lhe é semelhante, contíguo ou por ele produzido. ( $T N H$, p. 283)

Vale observar ainda que não é apenas ao fluxo do pensamento que as relações naturais conferem certa ordem e regularidade, mas também aos diversos gêneros discursivos: "um analista ou historiador que tome a peito tarefa de redigir a história da Europa durante um século qualquer será necessariamente influenciado pela conexão de contigüidade de tempo e lugar." (Ensaios Filosóficos sobre o Entendimento Humano, p.35) ${ }^{77}$ Associados às paixões, que impõem um objeto e um interesse ao discurso, esses princípios influem na organização dos gêneros de composição, fornecendo, simultaneamente,

77 Citamos segundo a edição fac-símile Olms Verlag. Hildesheim: 1978. 
uma direção ao autor e uma chave de análise para o trabalho do crítico $^{78}$. Seja no registro dos vários gêneros de discurso, seja no fluxo mental, as relações naturais como que indicam qual a transição mais fácil de uma idéia à outra, produzem uma tendência e são, numa palavra, o "cimento do universo" 79.

Mas é preciso perguntar de onde vem a naturalidade do associacionismo. Tomemos como ponto de partida para esse problema a explicação de Hume para a ação da contigüidade:

É evidente que assim como os sentidos, ao mudar de um objeto para o outro, só podem fazê-lo regularmente, tomando cada um deles em contigüidade ao outro, também a imaginação adquire, por longo costume, o mesmo método de pensamento, percorrendo as partes do espaço e do tempo ao conceber os objetos. $(T N H$, p.11)

O trecho acima chama a atenção, na medida em que ressalta a origem empírica desse modo de associação. A influência dessa relação sobre a imaginação deve-se, em primeiro lugar à experiência. Através dela criase uma tendência, um hábito é adquirido. E esse hábito nada mais é que a propensão a reproduzir no pensamento o mesmo "método" pelo qual os sentidos operam quando percorrem os objetos da sensação. No texto, a analogia entre os sentidos e o pensamento é fundamental. Pois é justamente por não ter sido estabelecido por nós, na medida em que ele vem da experiência, que esse hábito é natural.

Esse aspecto dos princípios de associação fica ainda mais evidente quando comparados às relações naturais e as relações filosóficas. As primeiras são tendências da imaginação, calcadas no hábito de proceder na associação das idéias, de maneira análoga ao encadeamento dos

\footnotetext{
${ }^{78}$ Exemplo disso é o breve comentário de Hume, no mesmo texto, acerca das Metamorfoses de Ovídio: "Ovídio formou seu plano baseado no princípio de conexão da semelhança. Toda transformação fabulosa, produzida pelo miraculoso poder dos deuses, inscreve-se nos limites da operação desse princípio." Ensaios filosóficos, pp. 35 - 6.
} 
dados sensíveis. Podemos reconhecê-las através de seus efeitos, quando observamos as seqüências de pensamento: "em nossos mais erráticos devaneios e mesmo em sonhos, a reflexão nos mostra que a imaginação não corre inteiramente à solta, mas há uma conexão entre as diferentes idéias que se sucedem umas às outras." (Investigação, p.13) As segundas, as relações filosóficas, são, por sua vez, arbitrárias e consistem na união de duas idéias na imaginação, sem a operação de nenhum "princípio de conexão". A causalidade, a semelhança e a contigüidade são, portanto, relações naturais quando não são frutos de uma decisão de estabelecer comparações. Noutras palavras, a tendência a relacionar idéias conforme esses princípios não é um produto da imaginação, mas o resultado de hábitos nela produzidos pela experiência a partir de qualidades comuns a ambas ${ }^{80}$.

Mas cabe perguntar agora: qual o significado dessa naturalização das relações de causalidade, semelhança e contigüidade para a filosofia humiana? Em primeiro lugar, essa tomada de posição implica dar aos princípios associativos o estatuto de princípios constitutivos da natureza humana. Nessa medida, no Tratado, e também no Resumo do Tratado e na Investigação, a associação de idéias ocupa um lugar fundamental. Os princípios de associação atuam como forças que tornam regulares as conexões estabelecidas entre as idéias da memória e os dados dos sentidos, ordenando a multiplicidade de nossas percepções e dotando-a de certa unidade e sistematicidade.

A partir dessas impressões ou idéias de memória nós formamos uma espécie de sistema, compreendendo o que quer que lembremos que tenha estado presente a nossas percepções ou sentidos. E a cada um dos particulares do sistema,

\footnotetext{
${ }^{79}$ Cf. Resumo do Tratado, p. 662.

${ }^{80}$ Nas palavras de Michaud: "De maneira geral há uma relação natural quando uma idéia evoca outra, a partir de uma qualidade associativa que elas compartilham. Diremos, por exemplo, que a semelhança liga A e B, e que A e B se assemelham." (Hume et la Fin de la Philosophie, p. 118)
} 
unido a uma percepção presente, havemos por bem chamar de realidade. (TNH, p. 108)

Sem essas relações o fluxo de pensamento correria à solta, e a coleção percepções que compõe a mente jamais se tornaria um sistema.

Mas a naturalidade das relações tem, além disso, uma outra conseqüência talvez mais ampla. Ao explicar o pensamento através de tendências naturais, Hume opõe-se as filosofias que consideram o homem sob um duplo ponto de vista, cindido entre uma parte racional e outra passional. Na realidade, além de serem determinações naturais do pensamento no sentido exposto acima, os princípios de associação possuem relações com as paixões que são indicativas da união do aspecto passional e do aspecto racional da natureza humana. Segundo o próprio Hume:

O homem, que é um ser racional que busca continuamente a felicidade e que espera obtê-la com a gratificação de alguma paixão ou afeto, raramente fala, age ou pensa sem propósito ou intenção. Ele tem sempre em vista um objeto; e, por mais impróprios que sejam os meios escolhidos para alcançar seus fins, nem por isso ele deixa de ter em vista um fim qualquer, nem trai seus pensamentos e reflexões, a não ser que espere colher deles uma satisfação qualquer. (Ensaios Filosóficos, p.33)

Entre o domínio do entendimento e o domínio das paixões não há senão uma unidade que, mesmo podendo ser desmembrada para fins de análise $^{81}$, como faz Hume ao tratar em separado desses temas em sua obra, é na realidade inseparável ${ }^{82}$. Exemplo disso é a célebre passagem

\footnotetext{
${ }^{81}$ Não se pode esquecer, além disso, que para Hume o homem é também um ser social. Nessa medida, a divisão do Tratado em três livros abordando o entendimento, as paixões e a moral, deriva da necessidade de separar três aspectos fundamentais da natureza humana para fins de análise.

82 Cf. Deleuze, Empirismo e Subjetividade, p.2.
} 
do Tratado na qual Hume propõe com todas as letras a tese da submissão da razão às paixões.

O exame da natureza humana exigirá da ciência do homem que considere seu objeto como inscrito na natureza e por ela determinado. A essa disciplina fica, portanto, vedada a possibilidade de considerar seu objeto em abstrato, separado das condições reais e circunstâncias nas quais ele se inscreve no mundo. Daí, o lugar fundamental que a história ocupa no pensamento humiano. Essa disciplina tem, por um lado, uma função formadora e educativa. A narrativa do historiador entretém a imaginação e nos inclina para a virtude ${ }^{83}$.

Mas, em Hume, o "uso principal" dessa disciplina é o "de descobrir os princípios universais e constantes da natureza humana, mostrando os homens em todas as variedades de circunstâncias e situações; e fornecendo-nos materiais a partir dos quais podemos formar nossas observações e nos familiarizarmos com os princípios regulares da ação e do comportamento humanos." (Investigação, p.83). Através da história o filósofo obtém acesso a um material mais rico e vasto que supera de longe aquele oferecido pela observação imediata dos fatos: "de um homem familiarizado com a história pode ser dito, em certo sentido, que ele vive desde o início do mundo e vem realizando, com o passar dos séculos, acréscimos a seu repertório de conhecimentos." (Do estudo da história, p. 567) $)^{84} \mathrm{O}$ papel da história na ciência da natureza humana é análogo ao dos experimentos e da observação para a física e a medicina. O historiador descreve eventos e ações de acordo com sua ordem natural e essa narrativa deve ser construída de modo a permitir a identificação de regularidades, circunstâncias e princípios que

\footnotetext{
${ }^{83} \mathrm{~A}$ atribuição dessa dupla função à história é, diga-se passagem, um ponto comum entre boa parte dos pensadores do iluminismo escocês. Sobre isso cf. Alexander Broadie, The Scottish Enlightenment, pp.43-58.

84 Os Ensaios morais, políticos e literários são citados segundo a edição de E. F. Miller. Indianapolis: Liberty Fund, 1985.
} 
determinam a natureza do homem. Por isso, a relação de causa e efeito será fundamental na constituição da narrativa histórica. Além de encontrar nas relações de contigüidade de tempo e lugar um encadeamento natural de seu relato, ao tecer seu discurso o historiador deverá ressaltar os nexos causais que entre os eventos que relata ${ }^{85}$. 0 estudo da história é a fonte por excelência do estudo da natureza humana, pois é nele que podemos isolar princípios regulares e retraçar ligações causais que determinam as feições dessa natureza.

A ênfase de Hume no que concerne à necessidade de o historiador dissecar as causas dos eventos que relata não é, de forma alguma, gratuita. Na doutrina da associação de idéias a relação de causalidade ocupa um lugar privilegiado. Dentre os três princípios associativos é causalidade que produz a conexão mais forte extensiva entre nossas percepções ${ }^{86}$. A relação de causa e efeito é capaz de ligar seus conteúdos de diversas maneiras: é por ela que se estabelecem tanto as relações de consangüinidade, assim como a relação de dois objetos, quando um é ou pode vir a ser causa dos movimentos, das ações ou da existência de um outro ${ }^{87}$. E não é exagero dizer que a causalidade é a principal e a mais forte ligação entre os objetos da experiência. Além disso, conexão causal é extremamente importante de um ponto de vista prático. Nas palavras de Hume, ela é a relação "mais instrutiva, pois apenas por esse conhecimento nos tornamos capazes de controlar eventos e governar o futuro." (Ensaios Filosóficos, p.36).

\footnotetext{
${ }^{85}$ Ensaios Filosóficos sobre o entendimento humano, p. 35.

${ }^{86} \mathrm{~A}$ semelhança relaciona os objetos similares (por exemplo, uma pintura e o seu original) e a contigüidade nos faz percorrer objetos que são adjacentes uns aos outros no espaço ou que se seguem no tempo. Sobre isto cf. por exemplo, Investigação, p.137.

${ }^{87}$ Cf. $T N H$, p.12.
} 


\section{IV}

Regrada pelos princípios de associação de idéias, a imaginação ocupa no pensamento humiano um lugar central e distinto daquele the era atribuído pela tradição filosófica e médica da época. A nos fiarmos no comentário de Dennis Todd em seu Imagining Monsters, tanto a medicina quanto a filosofia, desde Aristóteles até o final do século XVIII, atribuem à imaginação o papel de realizar a "sutura estreita" entre o corpo e a mente, entre o "racional" e o "corpóreo"88. Sob a inflexão do dualismo corpo-mente, para filósofos e médicos modernos as imagens produzidas pela imaginação são consideradas necessárias para a comunicação entre a substância corpórea e a incorpórea. É através delas que a mente pode pensar aquilo que foi apreendido pelos sentidos, e, inversamente, é também pela imaginação que a mente pode agir sobre o $\operatorname{corpo}^{89}$. Evidentemente, nessa operação são necessárias mediações, quase tão numerosas quanto os autores que abordaram o tema.

Essa concepção da imaginação implicava ainda a face fantasiosa e desregrada dessa faculdade. Situada na parte mais baixa do espírito, a imaginação desempenha a função de relacionar as duas substâncias (corpórea e incorpórea), mas, justamente por se situar no espírito, ela não é limitada pelas relações existentes no mundo sensível e é livre para compor imagens fictícias a seu bel-prazer.

Como medium entre sentido e pensamento, a imaginação realiza o trabalho de ambos. Ela é o mensageiro dos sentidos, criando imagens que replicam com exatidão o mundo externo. Mas a imaginação também serve ao intelecto e, tal ele, não está "presa às leis da matéria", mas "tem o direito de celebrar casamentos e divórcios ilegítimos entre as coisas ${ }^{90}$, extraindo objetos de

\footnotetext{
${ }^{88}$ Cf. Denis Todd, Imagining Monsters, II, 3, pp. 52-53.

${ }^{89}$ Sobre a interação das instâncias corpórea e mental cf. Imagining Monsters, pp. 54-63.

${ }^{90} \mathrm{O}$ trecho citado por Todd foi extraído de Bacon, De augmentis, In: The Works of Francis Bacon, Robert L. Ellis e Douglas Denon Heath (orgs.), vol.4, p. 315.
} 
sensação de suas contingências originais de posição no espaço e sucessão no tempo, de "juntar à vontade o que a natureza separou e separar o que ela uniu". (Imagining Monsters, p. 57)

Assim, se a imaginação é a faculdade que opera a comunicação entre corpo e mente, ela é, também, o poder de, por associação, formar imagens que em nada espelham a realidade das coisas. Tomada nesse sentido a imaginação é fantasia e representa um risco para o conhecimento e para o bom funcionamento da mente.

Embora não se refira nominalmente à imaginação, a não ser usando o termo fantasia (fancy), Locke, que além de filósofo era médico, não vê a associação de idéias com bons olhos ${ }^{91}$. Em seu capítulo sobre esse tópico o filósofo inglês não hesita em comparar esse modo de relacionar conteúdos mentais à loucura e ressaltar seu caráter extravagante e algo arbitrário. A associação de idéias, da qual trata o capítulo XXXIII da $2^{a}$ parte do Ensaio sobre o Entendimento Humano, não resulta da "correspondência natural" entre seus termos, mas do acaso. Ela nada tem haver com a verdade, considerada como a correta "junção ou separação dos signos, assim como das coisas por eles significadas, que concordam ou discordam entre si." (Locke, Ensaio, IV, 5 , p. 508). Não é a descoberta (pela razão) desse acordo ou desacordo que move a associação, mas o acaso ou o costume ${ }^{92}$. Essa operação caracteriza-se pela ausência de regra e de discernimento. Talvez não seja exagero dizer que na associação pura e simples há ainda mais desregramento que nas produções do engenho (wit), palavra que em Locke designa a capacidade de juntar idéias com "rapidez" e "variedade", de modo a produzir "visões agradáveis" para a "fantasia" (fancy). Tal como a pura associação, o engenho nos confunde e turva o

\footnotetext{
${ }^{91}$ Sobre a influência da medicina no pensamento de Locke cf. Duchesneau, John Locke, op. cit.

${ }^{92} \mathrm{Cf}$. Locke, Ensaio sobre o Entendimento Humano, p. 23.
} 
conhecimento ao unir idéias que o juízo separaria, mas em suas produções ainda é necessário algum discernimento para saber quais os elementos que juntos são capazes de agradar a fantasia e receber a aprovação de um público ${ }^{93}$.

Não encontraremos em Hume nem a preocupação em resolver o problema da comunicação entre corpo e mente, assunto deixado deliberadamente para a fisiologia, nem essa prevenção com relação à imaginação e a conseqüente condenação da associação. É verdade que o pensamento humiano, como a tradição à qual nos referimos brevemente acima, considera a imaginação como instância na qual a associação de idéias tem lugar, inclusive na produção de fiç̧ões. A imaginação é, como já dissemos, a faculdade de "compor, transpor, aumentar e diminuir os materiais fornecidos a nós pelos sentidos e pela experiência" (Investigação, p. 19). Mas é verdade, também, que em seu sistema, devemos à imaginação, e não à razão, a capacidade de realizar inferências. Afinal, é por ela que somos capazes de ligar os diversos conteúdos empíricos.

Essas ligações revelam-se ordenadas justamente devido aos princípios associativos. Longe de ser aleatória e arbitrária, a associação de idéias é, para Hume, o que confere regularidade e ordem ao movimento das idéias, seja em nossos raciocínios mais sóbrios, seja na produção das obras literárias, seja nos delírios ou ainda na estrutura do discurso. Pois, embora não suprimam a liberdade daquela faculdade, as relações naturais imprimem-lhe uma tendência e favorecem a regularidade de seu funcionamento. Indo mais longe, poderíamos até mesmo afirmar que sem elas, a imaginação permaneceria como faculdade da associação aleatória e jamais poderia tornar-se

${ }^{93}$ Cf. Locke, Ensaio sobre o Entendimento Humano, pp. 152-154. 
entendimento ou razão, ou ainda articular um discurso coerente sobre a experiência.

A associação de idéias não é fundamental apenas para a superação das conseqüências da ontologia da descontinuidade. Ela é também um modo de explicação e uma via para a análise dos fenômenos mentais que está de acordo com o projeto humiano de aplicar o método experimental aos assuntos morais. Bem no espírito da ciência desenhada na introdução do Tratado, a associação fornece princípios gerais através dos quais é possível elaborar algo semelhante a uma "mecânica" da mente. Na formulação dessa "mecânica" a inspiração newtoniana se manifesta em seus termos e em sua constituição: "eis aqui uma espécie de ATRAÇÃO, cujos efeitos no mundo mental se revelarão tão extraordinários quanto aqueles que produz no mundo natural, assumindo formas igualmente numerosas e variadas." (TNH, p. 13) O emprego da palavra "atração", devidamente destacada em maiúsculas pelo autor, assinala de forma mais que evidente essa inspiração. Mas, mais que isso, o uso das relações naturais bem como o papel central que elas desempenham corroboram essa afirmação. Todas as produções da mente são em algum grau analisáveis a partir desses princípios e serão discutidas por Hume nesses termos. Daí, talvez, a ordem de exposição da parte 1 do livro um do Tratado; no qual, após a apresentar ao leitor a doutrina da associação de idéias, o autor parte para uma primeira abordagem das Relações, Modos e Substâncias, culminando com a análise das Idéias Abstratas $^{94}$.

Não confundamos, no entanto, o estatuto desses princípios. A apresentação das relações naturais se realiza dentro dos limites

\footnotetext{
${ }^{94}$ Vale lembrar aqui o comentário de Michaud que ressalta adequadamente o fato de que todos os produtos da "vida mental" são analisáveis do ponto de vista das relações naturais, embora não possam ser esgotados sem o recurso a outras categorias de conceitos como o de inclinação, tendência e etc. Cf. Hume et la Fin de la Philosophie, p.117.
} 
impostos pelo método experimental, conforme exposto na introdução do Tratado: "seus efeitos são manifestos em toda parte; quanto a suas causas, porém, estas são no mais das vezes desconhecidas, reduzindose a qualidades originais da natureza humana que eu não tenho a pretensão de explicar." ( $T N H$, p. 13) Não se trata de determinar os princípios últimos ou originais da atividade mental, mas de reduzi-las a seus princípios mais gerais e econômicos. As relações naturais traduzem tendências regulares da imaginação na conexão de suas idéias, conexões estas que fazem da coleção de percepções algo articulado e dotado de um significado. Daí talvez o tom entusiasmado de Hume, ao concluir o Resumo do Tratado:

Perpassa o livro a pretensão a novas descobertas em filosofia; mas, se há algo que pode intitular o autor a um nome tão glorioso quanto o de inventor, é o uso que ele faz do princípio de associação de idéias, o qual está presente em praticamente toda a sua filosofia. (Resumo, p. 662) 


\section{Capítulo III - Uma Nova Definição de Necessidade}

I

As relações naturais por certo oferecem uma perspectiva para os problemas colocados pelo empirismo rigoroso e pela ontologia da descontinuidade integral que the é solidária. A semelhança, a contigüidade e a causalidade desvendam os processos da imaginação e fornecem uma chave para compreender os diversos movimentos, passagens e transições do pensamento. Nos princípios de associação Hume encontra uma via para examinar e operar a crítica de idéias complexas que não têm impressão correspondente na experiência (como as de substância e modo, as idéias abstratas e a idéia de Self), bem como um nexo que torna inteligíveis as diversas cadeias de pensamento, mesmo as mais soltas e delirantes, e a formulação das relações filosóficas. São as relações naturais que asseguram a constância das operações da imaginação; e é através delas que, a despeito da liberdade dessa faculdade, o filósofo escocês pode determinar regularidades que lhe permitem delinear os primeiros aspectos fundamentais da natureza humana.

Todavia, a principal relação natural possui contornos problemáticos que o próprio Hume é o primeiro a reconhecer. A causalidade - a mais extensiva dentre as três relações naturais - leva a imaginação a inferir um objeto ausente, a partir de um objeto presente, ultrapassando os dados da experiência. Conforme o texto do Tratado:

Mas a mente não se detém aqui. Constatando que, a par desse sistema de percepções, há um outro, conectado pelo costume, ou, se quiseres, pela relação de causa e efeito, ela procede à consideração das idéias que o perfazem. E, como ela se sente de alguma maneira impelida a examinar cada uma das idéias particulares, e como sente ainda que o costume ou relação que a impele não 
admite a menor variação, ela as conforma a um novo sistema, o qual ela agracia como o nobre título de realidade. (TNH, p.108)

Essa relação não apenas traz à mente a idéia de um objeto não dado, mas nos faz crer em sua existência, leva-nos a concebê-lo como real, em pé de igualdade com os dados dos sentidos e os registros da memória. Na formulação precisa de Deleuze:

O privilégio da causalidade é que por si mesma ela pode nos levar a afirmar a existência, nos levar a crer. Ela confere à idéia do objeto uma densidade, uma objetividade que seria impossível se só houvesse associação por contigüidade ou por semelhança à impressão presente. (Empirismo e Subjetividade, p.5)

A relação causal leva a mente para além do âmbito dos dados imediatos da experiência. É esse privilégio de conceder "solidez" a idéia um objeto ausente que determina, por um lado, a importância da relação de causa e efeito, e que, por outro, põe em questão a própria inferência causal. Pois, se no quadro definido pelo princípio da diferença e da separação toda relação é extrínseca a seus termos, não é trivial validar uma inferência que liga um objeto presente a um objeto ausente. $E$, quase como corolário desse problema, é preciso colocar sobre suspeição a idéia de uma conexão necessária entre a causa e seu efeito. Três questões emergem desse cenário: 1) como explicar a passagem do dado ao não dado, que a imaginação realiza a partir da relação causal?; 2) qual a natureza da crença que depositamos nessas inferências?; 3) qual a origem da idéia de conexão necessária ${ }^{95}$

\footnotetext{
${ }^{95} \mathrm{~A}$ própria formulação do problema da causalidade na Investigação sobre o Entendimento Humano mostra claramente que a filosofia humiana apresenta uma concepção inteiramente original da questão. As três questões expostas acima ressaltam, mais uma vez, a divergência entre o empirismo de Hume e a tradição racionalista. Afinal, a legitimidade da relação causal não seria um problema se o filósofo atribuísse às causas um poder produtivo, postulando uma ligação essencial entre os dois objetos. Tomem-se como exemplo as Meditações Metafísicas, onde podemos ler o seguinte: "(...) deve haver tanta realidade na causa eficiente e total quanto em seu efeito, pois de onde o efeito pode tirar sua realidade senão de sua causa?" Concebida como relação geradora, como exercício de um poder produtivo, a causalidade é formulada em
} 
Todavia, a problematização da relação de causa e efeito não deriva diretamente da ontologia da descontinuidade e do empirismo. Embora em última instância a coerência de Hume em relação a esses dois aspectos de seu pensamento não pudesse levar a outro lugar, tanto no Tratado quanto na Investigação, o exame do nexo causal é precedido pela apresentação de distinções importantes que delineiam o pano de fundo contra o qual a causalidade será discutida. Trata-se das conhecidas distinções entre conhecimento e probabilidade (no Tratado), e entre relações de idéias e questões de fato (na Investigação).

Apresentada no início da parte III do primeiro livro do Tratado a distinção entre conhecimento e probabilidade opera uma divisão das diversas relações filosóficas, situando, de um lado, aquelas que dependem unicamente das idéias e, de outro, aquelas que "podem se transformar, sem que haja nenhuma transformação nas idéias." (TNH, p. 69). Entre as últimas estão as relações de tempo e espaço, identidade e causalidade. Todas essas relações estão sujeitas a alterações, caso haja mudanças nas circunstâncias que envolvem os objetos por elas considerados, ainda que as idéias dos mesmos permaneçam inalteradas. Assim, as relações de contigüidade e distância se transformam, se houver a menor mudança na situação dos objetos. $\mathrm{E}$, no que tange à identidade, é possível que dois objetos sejam perfeitamente semelhantes, apareçam no mesmo lugar em instantes diferentes, mas sejam numericamente distintos. Por último, o poder pelo qual um objeto supostamente produz outro nos é revelado não somente pela da consideração de suas idéias, como também mediante a observação de seqüências empiricamente dadas.

termos de uma conexão necessária e essencial entre dois objetos ou eventos - o que, no limite, ao menos dá algumas condições para deduzir o efeito a partir da causa inteiramente a priori. 
Dentre essas relações, somente a de causalidade envolve pensamento. Afinal, quando se trata da identidade e da posição dos objetos no tempo e no espaço, estamos diante de impressões presentes aos sentidos e percebemos uma relação entre elas. Nesses casos, o que ocorre não é exatamente um raciocínio, mas a "mera admissão passiva de impressões pelos órgãos dos sentidos." (TNH, p. 73) Trata-se antes de uma percepção que de um raciocínio. Aí reside a especificidade e a importância da relação de causa e efeito, ela é a única, como indicamos antes, pela qual somos capazes de inferir a existência de uma "ação ou objeto" que não estão imediatamente presentes aos sentidos. Todavia, a despeito dessa diferença entre a causalidade e as outras relações que compõem o campo probabilidades, há uma característica comum: todas elas são inteiramente dependentes da experiência e não podem ser realizadas a priori ${ }^{96}$. Pois, ainda que sejamos incapazes de pensar idéias contraditórias, no território das probabilidades nada obsta a ocorrência de eventos contrários. Essa peculiaridade das probabilidades faz com que o padrão de certeza das matemáticas não Ihes seja aplicável. Ainda que Hume cunhe uma categoria específica para as probabilidades mais fortes (as provas) ${ }^{97}$, mais adiante no Tratado, pode-se dizer com segurança que a certeza matemática está inteiramente excluída desse campo.

Muito diferente é o que ocorre com as relações de proporção de quantidade ou número, contrariedade, semelhança e graus de uma qualidade. Na medida em que dependem unicamente das idéias que comparam, elas são objeto de conhecimento e certeza e são inteiramente limitadas pelo princípio de contradição. Algumas delas nomeadamente a semelhança, a contrariedade e os graus de uma

\footnotetext{
96"Não há um só fenômeno, por mais simples que seja, que possa ser explicado pelas qualidades dos objetos, tais como estas aparecem a nós, ou que pudéssemos prever sem a ajuda de nossa memória e experiência." (TNH, pp. 69-70)

${ }^{97}$ Sobre a distinção entre provas e probabilidades cf. TNH, p. 124.
} 
qualidade - nem mesmo demandam raciocínio e podem ser estabelecidas "à primeira vista", nas palavras do autor. Por isso, tais relações pertencem ao domínio do que Hume chama de "intuição".

As proporções de quantidade e de número são as únicas relações desse grupo que requerem raciocínio. Quando almejamos alguma exatidão na determinação dessas proporções, ou quando se trata de objetos de magnitudes consideráveis, é preciso empregar razão e artifício. É exatamente essa espécie de relação que está, segundo Hume, no fundamento das matemáticas. E é através do exemplo da geometria que o autor mostra como, utilizando meios artificiais, somos capazes de sofisticar e tornar mais precisos os "juízos dos sentidos e da imaginação".

Os primeiros princípios [da geometria] são sempre extraídos da aparência geral dos objetos, o que jamais pode nos proporcionar segurança quando se trata de examinar a prodigiosa minúcia de que a natureza é capaz. Nossas idéias querem nos dar perfeita garantia de que duas linhas retas não podem ter um segmento em comum; mas, se as examinarmos, veremos que elas incluem a inclinação sensível das duas linhas, e que, quando o ângulo que elas formam se torna extremamente pequeno, não temos um padrão de linha reta que seja tão preciso a ponto de nos assegurar da verdade dessa proposição. (TNH, p.71)

A geometria emprega arte e raciocínio para tornar exatas as proporções estabelecidas pela imaginação e pelos sentidos. Mas a perfeição das matemáticas só é alcançável pela aritmética e pela álgebra. Pois só essas duas ciências dispõem de um critério que permite determinar a igualdade e a proporção numéricas com total exatidão. "E é por falta de um critério de igualdade semelhante aplicável à extensão que a geometria dificilmente pode ser considerada uma ciência perfeita e infalível". ( $T N H$, p. 71) A ausência desse critério tem uma razão de ser inerente à própria constituição da geometria. Embora essa ciência 
confira maior exatidão e universalidade a nossos primeiros juízos acerca da extensão, ela deriva seus primeiros princípios da aparência dos objetos. Tal deficiência impregnará inevitavelmente todos os desdobramentos desse saber. ${ }^{98}$

A distinção prévia entre probabilidades e conhecimento assinala que a análise da causalidade se realizará tendo como pano de fundo a recusa de Hume em aceitar um determinado modelo de razão e de ciência. O mesmo ocorre com a divisão correlata que abre a seção $4 \mathrm{da}$ Investigação sobre o Entendimento Humano e que, nessa obra também, precede a análise da causalidade.

Todos os objetos da investigação ou razão humana podem ser naturalmente divididos em duas espécies, quais sejam, relações de idéias e questões de fato. Da primeira são as ciências da geometria, álgebra e aritmética, ou, em suma, toda afirmação intuitiva ou demonstrativamente certa. (...) Questões de fato, que são a segunda espécie de objeto da razão humana, não são passíveis de uma certificação como essa, e tampouco nossa evidência de sua verdade, por grande que seja, é da mesma natureza que a precedente. O contrário de toda questão de fato permanece sendo possível porque não pode jamais implicar contradição, e a mente o percebe, com a mesma facilidade e clareza, como algo perfeitamente ajustável à realidade. (Investigação, p. 25)

Embora empregue novos termos e seja apresentada de forma mais sucinta, a separação das questões de fato e das relações de idéias tem a mesma natureza e as mesmas conseqüências que a clivagem apresentada no Tratado. Ambas são divisões das áreas do conhecimento humano, separando aquelas que podem ser conhecidas pela razão $a$ priori e aquelas que requerem a experiência. Em ambas trata-se também de delimitar dois modos de conhecer, para os quais há gêneros distintos de evidência. Longe de consistirem numa depreciação do

\footnotetext{
${ }^{98}$ Sobre a geometria e os outros ramos da matemática cf. TNH, pp.72-73.
} 
conhecimento dos fatos, as duas distinções assinalam a rejeição de uma concepção de racionalidade que seria igualmente aplicável aos domínios das questões de fato e das relações de idéias.

Nessa medida, a divisão proposta por Hume marca a distância que separa a filosofia humiana do cartesianismo. Ela mostra que o filósofo escocês não admite a tese cartesiana "não há razão senão enquanto razão universal" sempre idêntica a si mesma, não importando a pluralidade de objetos que ela examina ${ }^{99}$. Junto com essa concepção de razão é o ideal de uma mathesis universalis - "disciplina que deve conter efetivamente os primeiros rudimentos da razão humana e se estender para fazer brotar verdades a respeito de qualquer assunto." (Descartes, Regras para a Direção do Espírito, regra IV, p. 26). - que a filosofia humiana rejeita. Através da distinção entre questões de fato e relações de idéias, Hume pretende colocar as coisas em seus devidos lugares, mostrando que a matemática não pode ser elevada à condição de paradigma de toda a ciência, e que a demonstração não é um procedimento consistente com o conhecimento de fatos e objetos dos sentidos ${ }^{100}$.

Há também que se considerar, como bem indica Lebrun, que já a distinção entre provas e probabilidades mostrava uma diferença significativa entre Hume e Locke. Pois, ao adotar a terminologia lockiana e introduzir esse matiz, Hume de certa forma subverte a divisão operada pelo autor do Ensaio sobre o Entendimento Humano, ainda em

\footnotetext{
${ }^{99}$ Cf. C. A. Moura, Crítica Humiana da Razão, In: Racionalidade e Crise, p. 114.

${ }^{100}$ Vale notar que o argumento de Hume no Tratado reduz consideravelmente a confiança que se pode depositar nas matemáticas. Se o matemático podia sentir-se seguro em relação a seu saber na parte 3, do livro I, quando a álgebra, a geometria e a aritmética eram situadas no terreno do conhecimento, a seção 1 , da parte IV, irá mostrar que a inconstância de nossos "poderes mentais" faz com que as conclusões dessas ciências se degenerem em probabilidade. Ainda que as regras das ciências demonstrativas sejam infalíveis, sua aplicação é precária devido à falibilidade de nosso entendimento. Assim, na prática, mesmo no domínio do conhecimento há lugar para duvidar da certeza de nosso conhecimento. Haveria, portanto, uma segunda, por assim dizer, espécie de probabilidade, derivado das fraquezas de nossas faculdades. Sobre isto, cf. $T N H, I, 4,1$.
} 
algum grau marcada pela distinção entre necessário e contingente. Como afirma Lebrun:

Pois não é a mesma coisa dizer: 'abaixo do certo, há o provável' e 'fora do necessário, há o contingente'. Na segunda fórmula eu reafirmo o sublunar. (...) $\mathrm{Na}$ primeira fórmula não chego a dizer tanto. Não faço senão distinguir, por comodidade, duas rubricas da experiência, as quais me abstenho de transformar em duas regiões do ser: a) as causas tais 'que jamais se encontrou caso algum de falha ou irregularidade em suas operações'; b) as seqüências tais que, no passado, 'diferentes efeitos se seguiram de causas que, ao que parecia, eram exatamente similares". ( $A$ Boutade de Charing-Cross, In: $A$ Filosofia e sua História, p. 153).

Formulada desse modo, a distinção humiana entre provas e probabilidades não expõe uma hierarquia entre os saberes, na qual aqueles que são tributários da demonstração matemática ocupariam o topo. Ao contrário do que ocorre em Hume, no empirismo de Locke o conhecimento dos corpos é desvalorizado em comparação com as matemáticas, uma vez que nada sabemos das substância corpórea a não ser o que nos é dado pela experiência e história. O problema que Locke enxerga nesse caso é que a experiência não nos assegura senão o conhecimento das "essências nominais" desses objetos, mantendo ocultas suas "essências reais"101. Assim, um tanto paradoxalmente, esse empirismo conduz à suspeita de que "a filosofia natural dificilmente será capaz de ser transformada em ciência", ao contrário da moral. ${ }^{102}$

Mas voltemos à rejeição da mathesis. A censura de Hume ao ideal de conhecimento que ela expressa encontra caução na constatação de que, em se tratando das questões de fato, o princípio de nãocontradição não é suficiente para determinar a verdade de um enunciado qualquer, pois, a negação de um fato não envolve sua

${ }^{101}$ Cf. Locke, Ensaio sobre o entendimento humano, p. 569. 
contradição. "Tudo o que é pode não ser". (Investigação, p. 164) A proposição que nega a existência de um fato, ao contrário do que ocorre nas ciências abstratas, é inteligível e concebível. Nesse território os contrários não são contraditórios, de modo que não é possível constatar por demonstração a falsidade de nenhuma proposição que diga respeito aos objetos da experiência. Como afirma Hume, ainda na seção XII da Investigação:

Parece-me que os únicos objetos das ciências abstratas, ou objetos de demonstração, são quantidade e número; e toda tentativa de estender essa espécie mais perfeita de conhecimento para além desses limites não passa de sofística e ilusionismo. (Investigação, p. 164)

Ao contrário do que gostaria de poder fazer, por exemplo, o físico cartesiano $^{103}$, não é possível elaborar uma filosofia da natureza calcada na demonstração ${ }^{104}$. O que vale para a física nesse caso, vale para todos os saberes que versam sobre a "existência real de coisas".

O comentário humiano da relação de causa e efeito buscará elaborar uma concepção da inferência causal que seja compatível com a rejeição de um Logos inscrito na experiência, mas que, no contexto

102 Cf. Locke, Ensaio sobre o entendimento humano, p. 570.

${ }^{103}$ A crer na exposição de Cassirer seria esse o mote da física cartesiana. Cf. The Philosophy of Enlightenment, p. 51: "Começando com suas próprias idéias claras e distintas [o pensamento] encontra um modelo para a realidade como um todo. Princípios matemáticos e axiomas do pensamento o conduzem em segurança pelo reino da natureza. Pois há um caminho definido, uma única e ininterrupta cadeia de dedução que se estende das causas mais elevadas e gerais dos eventos naturais até as leis especiais da natureza e destas a cada efeito individual, não importa quão complexo ele seja. Não há barreira entre o reino dos conceitos claros e distintos e o reino dos fatos, entre a geometria e a física. Pois a substância do corpo físico consiste na pura extensão, isto é, a geometria é mestre da física."

${ }^{104}$ Esse movimento afasta Hume do empirismo lockiano. Pois se a clivagem realizada sob os termos conhecimento e probabilidades remetem o leitor ao Ensaio sobre o Entendimento Humano, a separação de domínios que eles nomeiam difere da concepção de conhecimento e probabilidade cunhada por Locke. Ainda que Locke situe na experiência a origem de todas as idéias, eliminando assim as idéias inatas, a definição de conhecimento elaborada pelo Ensaio mantém no horizonte a tese de que a demonstração é, por excelência, a via de qualquer saber digno do título de ciência. Sobre isto, cf. C. A. Moura, Crítica Humiana da Razão, In: Racionalidade e Crise, pp. 117-118. Cf. também, Owen, David, Hume's Doubts about Probable Reasoning: was Locke the Target?, In: Hume and Hume's Connexions, M.A. Stewart and John P. Wright (orgs.), The Pennsylvania State University Press, Pennsylvania, 1995. 
dessa recusa, garanta a possibilidade do conhecimento das questões de fato e assegure direito de cidadania a uma evidência própria a esse campo $^{105}$. É no interior dessa censura que a análise da causalidade se inscreve. Por isso, o exame terá como eixo principal, tanto na Investigação quanto no Tratado da Natureza Humana, a idéia de conexão necessária. Tratada nos termos implicados na distinção entre questões fato e relações de idéias, a natureza da conexão entre causa e efeito torna-se um enigma a ser deslindado por uma análise cerrada que ocupa boa parte do livro I do Tratado e é retomada nas seções 4 e 5 da Investigação.

Apesar desse eixo comum, há uma diferença importante na condução da análise da causalidade em cada uma destas obras: na Investigação sobre o Entendimento Humano a ênfase do texto recai no princípio da diferença e da separação, enquanto no Tratado o nexo causal é examinado à luz, sobretudo, do princípio do empirismo ${ }^{106}$. No último caso, Hume considera a relação de causa e efeito como relação filosófica; no primeiro, ela é discutida a partir das relações naturais e da inferência comum ao filósofo e ao homem ordinário. Contudo, a despeito das diferentes estratégias de análise, o resultado do exame é o mesmo nas duas obras.

\section{II}

O comentário da causalidade é introduzido no argumento da Investigação como conseqüência quase direta da caracterização da evidência peculiar ao campo dos fatos. Não por acaso, esse exame tem

\footnotetext{
${ }^{105}$ Como diz Malherbe em La Philosophie Empiriste de David Hume, p.118: "A questão da causalidade exige uma análise da função sintética do entendimento, análise essa que conduz à crítica de todo conhecimento empírico de leis e, consequentemente, da própria ciência newtoniana. A doutrina da causalidade é a doutrina da ciência da natureza."

106 Isso não significa, evidentemente, que no Tratado Hume suspenda a aplicação do princípio da diferença. O princípio do empirismo serve de fio condutor da análise; mas diferença e separação continuam a operar na discussão da relação causal. Sobre isso, cf. por exemplo, TNH, p. 84.
} 
como ponto de partida a pergunta pela natureza dos nossos raciocínios concernentes às existências reais.

E assim parece um tópico digno de interesse investigar qual é a natureza dessa evidência que nos dá garantias quanto a toda existência real de coisas e toda questão de fato, além do testemunho presente de nossos sentidos ou dos registros de nossa memória. (Investigação, p. 26)

A resposta a esta questão é que não estando fundados na demonstração, todos os raciocínios relativos a fatos e existências são calcados na relação causal. "É somente por meio dessa relação que podemos ir além da evidência de nossa memória e de nossos sentidos." (Investigação, p.26) Pela causalidade são realizadas tanto as inferências operadas pelo homem comum em seu cotidiano, quanto aquelas através das quais o cientista elabora as máximas de seu saber ${ }^{107}$. Todas as operações dos corpos, bem como as leis da natureza são conhecidas por meio dessa relação.

É essa constatação que orienta o trajeto a ser seguido nas Dúvidas Céticas sobre o Entendimento Humano. Afinal, uma vez que todo juízo empírico é obtido a partir da causalidade o objetivo da investigação se coloca naturalmente: "Assim, se quisermos no convencer acerca da natureza dessa evidência que nos assegura quanto a questões de fato, devemos investigar como chegamos ao conhecimento de causas e efeitos." (Investigação, p. 27)

O primeiro passo a ser dado aqui consiste em desdobrar uma das conseqüências mais evidentes da exclusão da necessidade:

O conhecimento dessa relação [de causalidade] não é, caso algum, alcançado por meio de raciocínios a priori, mas provém inteiramente da experiência, ao

\footnotetext{
107"Um homem que encontre um relógio ou qualquer outra máquina numa ilha deserta concluíra que homens estiveram anteriormente nesta ilha." (Investigação, p. 26).
} 
descobrirmos que certos objetos particulares se encontram constantemente conjugados uns aos outros. (Investigação, p. 27)

Diversos exemplos ilustram essa conclusão, num movimento que vai da hipótese de um homem que se depara pela primeira vez com um determinado objeto passando pela suposição acerca da situação inicial de Adão, o primeiro homem, até apelar à experiência do próprio leitor.

Em todos os casos, chega-se à mesma conclusão. Assim, um homem "dotado das mais poderosas capacidades naturais de raciocínio e percepção" seria incapaz de descobrir as causas e efeitos de um objeto na primeira vez que se depara com ele. E Adão, por ter sido o primeiro homem, não conseguiria, num primeiro momento, inferir da "fluidez e transparência da água que ela o sufocaria, nem da luminosidade e do calor do fogo que este poderia consumi-lo"108. Com efeito, o problema que os exemplos ilustram não está apenas na constatação de que o raciocínio abstrato é incapaz de revelar as propriedades dos objetos, mas também no fato de que não é qualquer experiência que nos informa sobre as causas e efeitos dos objetos. Mostra-se que as qualidades sensíveis de um objeto não nos permitem inferir nenhum de seus efeitos. Para que conheçamos a relação causal é necessário que tenhamos observado a conjunção repetida de dois objetos.

Isso é ainda mais claro, quando se considera a determinação dos efeitos menos usuais, que "têm pouca analogia com o curso ordinário da natureza". Ninguém poderia antecipar uma explosão apenas a partir das qualidades sensíveis da pólvora, e tampouco um homem seria capaz de prever o fenômeno da atração, simplesmente por conhecer a aparência de um imã. Nesses casos fica patente que, para usarmos uma expressão que Hume empregará mais adiante, os "poderes secretos" de um objeto

108 Cf. Investigação, p.27. 
não são revelados por suas qualidades sensíveis. Se não fosse assim, aliás, a síntese causal poderia perfeitamente ser deduzida a partir da experiência que tenho da aparência do objeto. Posto de outra forma, bastaria que conhecêssemos o conceito adequado de um objeto qualquer para que pudéssemos demonstrar seus efeitos e suas causas. Mas, como faz questão de insistir Hume:

Objeto algum jamais revela, pelas qualidades que aparecem aos sentidos, as causas que o produziram ou os efeitos que dele provirão, e nossa razão é incapaz de extrair, sem auxílio da experiência, qualquer conclusão a respeito da existência efetiva de coisas ou de questão de fato. (Investigação, p. 27)

Nem mesmo um fenômeno trivial, como o movimento das bolas de bilhar, poderia ser explicado dessa maneira. Nenhum evento é conhecido sem a experiência da conjunção constante, do mais ao menos usual dos fenômenos, do mais particular a mais geral das leis da natureza. Mas aqui é preciso refinar essa conclusão. Pois, como mostra Hume no Tratado, a mera contigüidade de dois objetos não é suficiente para que os consideremos como ligados pela causalidade. Do contrário, todos os objetos contíguos seriam considerados como causas ou efeitos um do outro ${ }^{109}$.

Assim, não obstante recorra a argumentos de experiência que mostram que numa primeira exposição a um objeto até então desconhecido somos incapazes de traçar seus efeitos e suas causas, na Investigação Hume faz questão de ressaltar que o "efeito é um acontecimento distinto da causa"110. "Ele não poderia, por isso mesmo, ser descoberto na causa e sua primeira invenção ou concepção a priori deve ser inteiramente arbitrária." (Investigação, p. 29) Ora, não só os termos da relação causal são distintos e independentes entre si, como

\footnotetext{
109 Sobre isto, cf. Investigação, pp. 57-58.

110 Cf. Investigação, 4, 1, p. 29.
} 
as qualidades sensíveis do objeto são distintas de quaisquer poderes que eles possam porventura possuir. Esse é o motivo pelo qual um homem primevo, como Adão, é incapaz de inferir os efeitos ligados a um objeto pela simples consideração da aparência do mesmo em sua primeira aparição. No limite, a arbitrariedade do raciocínio a priori nesse domínio explica-se pelo fato de que não há como traçar qualquer relação entre eles, sem lançar mão da experiência de sua conjunção constante, pois, a causa e o efeito são objetos distintos e podem ser concebidos separadamente pela imaginação ${ }^{111}$.

A sua dependência em relação à experiência define muito do feitio da ciência da natureza humana e justifica a restrição metodológica que impede Hume de chegar aos princípios últimos da ciência do homem. 0 filósofo experimental conseqüente, conforme indica o texto da $1^{\text {a }}$ Investigação, não pretende desvendar essas causas. Seu trabalho limita-se a buscar os princípios mais simples e gerais, e a reduzir o maior número possível de fenômenos à menor quantidade de causas. Com efeito, o recuo aquém desses princípios levaria a um contra-senso, na medida em que a investigação se dirigiria necessariamente a uma instância anterior à própria experiência e, portanto, inacessível ao entendimento humano. No que concerne a esse gênero de investigação Hume é taxativo: "Esses móveis princípios fundamentais estão totalmente vedados à curiosidade e à investigação humanas." (Investigação, p. 30) A boa filosofia envolve a consciência clara desses limites e requer a sua observância.

$E$, ainda que a matemática venha a ser aplicada a esse domínio, não devemos nos enganar quanto ao fato de que o conhecimento desses

\footnotetext{
${ }^{111}$ No Tratado, após fracassar na tentativa de determinar a origem do vínculo causal através da aplicação do princípio do empirismo à idéia de causação, Hume propõe a hipótese de que essa ligação talvez pudesse vir de uma relação e mostra que a causalidade envolve a contigüidade (no tempo e no espaço), pois trata-se de uma sucessão espaço-temporal. Todavia, esse caminho também fracassa, pois, nem todos os objetos contíguos são considerados como causas e efeitos. Cf. $T N H$, pp. 73-74.
} 
objetos deriva da experiência. O exemplo utilizado por Hume para expor esse ponto, não por acaso, é o da física. A dependência desse saber em relação à experiência e à observação é da própria natureza das questões de fato e, por isso, mesmo quando a matemática vem em seu auxílio, as proposições da filosofia da natureza continuam a ser inteiramente derivadas da observação e da análise. É desses procedimentos, e não do raciocínio abstrato, que advém a descoberta das regularidades que poderão ser elevadas à condição de leis gerais dessa ciência ${ }^{112}$.

Essas conclusões são etapas importantes para fundamentar a ultrapassagem do dado sensível na relação causal, bem como para explicar a natureza dos raciocínios acerca dos objetos empíricos no quadro desenhado a partir da distinção entre questões de fato e relações de idéias. Todavia, é preciso ressaltar que os passos dados até aqui servem para limpar o terreno. Trata-se somente de mostrar, por diversos ângulos, que o conhecimento das questões de fato repousa na relação de causa e efeito, e que essa relação não é cognoscível senão pela experiência. Nessas Dúvidas Céticas o argumento envolve uma regressão em direção ao problema do fundamento, e a cadência dessa investigação é pautada pelos obstáculos que ela encontra. Pois, respondida a questão acerca da base de nossos raciocínios sobre os fatos chegamos à relação de causalidade, coloca-se então a pergunta pelo fundamento da causalidade; mas, quando somos capazes de situálo e descobrimos que ele se localiza na experiência, somos levados a uma nova questão, que é a da base de nossos raciocínios experimentais ${ }^{113}$. É esse movimento que Hume faz questão de ressaltar quando abre a segunda parte das Dúvidas Céticas, formulando expressamente as questões que serviram de fio condutor da análise e

\footnotetext{
${ }^{112}$ Nunca é demais notar que o uso da física como exemplo não é trivial. Pois, é essa ciência serve a Hume de inspiração no desenho de seu projeto filosófico e the oferece um modelo de método e de evidência, como já indicamos antes.

${ }^{113} \mathrm{Cf}$. Investigação, p.32.
} 
colocando um último problema a ser resolvido: "se perseverarmos em nosso espírito inquisitivo e perguntarmos, qual é o fundamento de todas as conclusões a partir da experiência?, introduziremos uma questão nova, possivelmente mais difícil de solucionar e esclarecer." (Investigação, p. 32)

O empirismo humiano não se contenta em sancionar, sem mais, a tese segundo a qual o conhecimento dos fatos só é possível a partir da experiência, atribuindo a essa última o papel de fiadora de nossas inferências. Nessa filosofia, a própria experiência será comentada a partir da adesão integral de Hume à tese segundo a qual as relações são exteriores a seus termos e será examinada a partir dos modos de afecção das mente humana. Por isso mesmo, o exame da causalidade não pára na constatação de que toda inferência causal encontra caução na experiência. Pelo contrário é preciso determinar por que, a partir da experiência, somos levados a realizar inferências causais. A explicação dessa operação passa justamente pela identificação do fundamento de nossas conclusões empíricas.

A resposta de Hume a essa questão é conhecida. Após reiterar tanto a exclusão da demonstração quanto a impossibilidade de conhecer os "poderes secretos" dos objetos a partir de suas qualidades sensíveis, Hume localizará na inferência causal uma certa crença na uniformidade da experiência. Mas essa crença é ela mesma problemática. A verdade dessa suposição está longe de ser garantida, pois ela diz respeito a uma questão de fato e não há contradição em considerar que o curso da natureza possa alterar-se ${ }^{114}$. Pois "estas duas proposições nem de longe são a mesma: constatei que tal objeto sempre esteve acompanhado de tal efeito; prevejo que objetos semelhantes serão acompanhados de

114 Cf. Investigação, pp.36-37: "Se houver qualquer suspeita de que o curso da natureza pode mudar e de que o passado não mais seja a regra para o futuro, toda experiência se tornará inútil e dela não poderá surgir qualquer inferência ou conclusão." 
efeitos semelhantes." (Investigação, p. 34). A segunda proposição não resulta da análise da primeira. Tampouco, são elas intuitivamente certas. Não obstante essa constatação, é fato que em meus raciocínios causais tendo a considerar que a experiência passada se repetirá no futuro. O problema, nos termos postos por Hume, é que se essa passagem é de fato o resultado de um raciocínio, deve haver então um termo médio que faz a ligação entre a primeira e a segunda proposição.

A gênese de um argumento que liga essas duas proposições, através de um termo médio parece fadada ao fracasso. Pois, excluída a possibilidade de que a relação entre ambos os enunciados seja determinada por demonstração, resta que ela só pode ser justificada por um raciocínio moral, nome que Hume dá aos raciocínios sobre os fatos; e todos os raciocínios dessa espécie são dependentes da relação causal ${ }^{115}$. Considerada desse ponto de vista, a questão do fundamento de nossas inferências por experiência nos enreda num círculo vicioso.

Dissemos que todos os argumentos relativos a existência se fundam na relação
de causa e efeito; que nosso conhecimento deriva inteiramente da experiência;
e que todas as nossas conclusões experimentais procedem da suposição de que
o futuro estará em conformidade com o passado. Em vista disso, esforçar-se
para provar essa última suposição por meio de argumentos prováveis ou por
argumentos que dizem respeito à existência é, evidentemente, andar em
círculos e tomar como dado o ponto que está sendo debatido. (Investigação,
pp. $35-36$ ) Hume insistirá nesse ponto ao longo de todo o resto das Dúvidas Céticas. A razão experimental se funda na semelhança entre causas e efeitos, e na suposição de que não haverá alterações no curso da natureza. Sua máxima poderia ser, como formula Hume: "De causas 
que parecem semelhantes esperamos efeitos semelhantes; tal é a suma de todas as nossas conclusões experimentais." (Investigação, p. 36) É preciso explicar de onde vem essa expectativa, e de que fundamento ela tira sua evidência. A dificuldade dessa tarefa reside no fato de que ao tentarmos explicar a suposição da uniformidade da natureza através de um raciocínio moral, estaríamos nos esquecendo de que a própria evidência desses raciocínios repousa sobre essa suposição.

Para evitar tal círculo é preciso abandonar essa perspectiva do problema. A dificuldade que nos leva à aporia reside no fato de considerar-se a questão como a relação entre duas proposições de um argumento, como se a inferência causal derivasse inteiramente da razão, mesmo que não se trate mais da razão demonstrativa. Se assim fosse, seríamos capazes de realizar inferências causais a partir de um caso único. "Nada se assemelha tanto quanto os ovos, e ninguém, no entanto, com base nessa similaridade aparente, espera encontrar em todos eles o mesmo gosto e sabor." (Investigação, p. 36) Não há nenhum raciocínio que me permita partir de um caso isolado de conjunção para estabelecer uma causalidade. É apenas após a repetição de uma conjunção que somos levados a concluir que dois objetos estão relacionados causalmente. $E$, ainda que se admita que a repetição de casos semelhantes é indispensável para o estabelecimento dessa relação, se fixarmos seu princípio no mero raciocínio, voltaremos ao problema do qual partíramos ${ }^{116}$.

Esse é o principal nó com o qual se deparam as Dúvidas Céticas. 0 curioso é que, embora a investigação acerca do termo médio desse raciocínio seja uma tarefa intrincada, mesmo o camponês mais ignorante é capaz de estabelecer vínculos causais em seus raciocínios.

\footnotetext{
${ }^{115}$ Cf. Investigação, 4, 2, p. 35 : "Todos os raciocínios podem ser divididos em duas espécies, a saber, raciocínio demonstrativo, que diz respeito às relações de idéias, e raciocínio moral, referente a questões de fato e existência ."

${ }^{116}$ Cf. Investigação, pp. 36-37.
} 
Aquilo que causa embaraço ao filósofo, é realizado sem maiores pelo ignorante e pela criança. É verdade que nenhum deles se indaga a respeito do fundamento e da legitimidade de seus juízos, mas, nem por isso, a situação deixa de ser paradoxal, ao menos à primeira vista. Afinal trata-se de constatar que não há "nenhum argumento ou processo do entendimento" subjacente à relação que está na base de todos os nossos raciocínios morais.

Não é à toa que Hume encerra suas dúvidas céticas com essa constatação. O resultado dessas dúvidas é a conclusão de que, embora realizemos inferências causais na ciência e na vida comum, a evidência da causalidade não pode ser fundamentada nem pelo raciocínio a priori, nem pelo raciocínio a posteriori. O que os casos do camponês e da criança sugerem é que o filósofo está considerando a questão pelo ângulo errado. Para escapar à aporia é preciso assumir um outro ponto de vista. Em vez de perguntar qual a lógica que nos assegura a uniformidade do passado e do futuro, é preciso buscar um princípio da natureza humana que explicite a crença que depositamos na regularidade da natureza. Afinal, de um ponto de vista estritamente lógico, a conjunção entre a causa e o efeito pode ser meramente casual, na medida em que ambos são objetos distintos, sem nenhuma relação essencial que os una.

Essa mudança de perspectiva sugerida ao fim das Dúvidas Céticas sobre as Operações do Entendimento assemelha-se à estratégia utilizada no Tratado. Pois ali, após tomar como ponto de partida a análise da relação filosófica de causalidade, o texto muda seu curso e passa a discutir a inferência causal, tomando a causalidade como relação natural. Tratar a questão no registro do associacionismo é uma guinada significativa. Com o deslocamento do problema para o terreno das relações naturais ou da associação de idéias, a questão passa a residir na explicação de como é possível que a imaginação realize 
transição da causa ao efeito. Considerada como relação filosófica, o máximo que se pode dizer a respeito da conexão entre causa e efeito é que ambos devem sempre se encontrar numa conjunção na qual a causa deve preceder o efeito, mas nada se pode acrescentar quanto ao princípio que nos leva a atribuir necessidade à relação entre esses dois termos. Mesmo raciocinando sobre a conjunção constante de dois objetos o entendimento não pode descobrir nenhuma conexão intrínseca a ambos, e os sentidos, tampouco, podem nos dar qualquer pista da conexão que supomos existir. Mas, pensando em termos da mera associação de idéias, é possível buscar um princípio da natureza humana que explique a evidência que atribuímos a essa relação.

\section{III}

É através de um exemplo semelhante ao de Adão que Hume introduz a solução para as questões levantadas na seção anterior. A suposição agora diz respeito a um homem que, na plenitude de suas faculdades de razão e reflexão, é subitamente posto no mundo. Embora desde esse momento inicial toda uma sucessão de fenômenos se desenrole diante dele, tal homem será incapaz de realizar inferências causais. $\mathrm{O}$ argumento reproduz quase que exatamente o caso analisado por Hume nas dúvidas céticas. A dificuldade inicial desse sujeito reside no fato de que "os poderes particulares" dos objetos que ele tem diante de si não se revelam aos sentidos, e não é, portanto, possível inferi-las através de qualquer raciocínio.

A simples observação do fluxo contínuo dos fenômenos que se desenrola diante dele não Ihe permite nem mesmo, como Hume faz questão de notar, "alcançar a idéia de causa e efeito". O argumento humiano insiste no fato de que não basta a esse sujeito testemunhar que um objeto precede o outro para cunhar a idéia de causalidade e estabelecer uma relação desse gênero entre dois eventos. É necessária 
a repetição da experiência e a observação de cadeias semelhantes para que tal homem comece a antecipar a existência do efeito a partir da causa.

Suponha agora que ele adquiriu mais experiência e viveu no mundo o suficiente para ter observado objetos ou eventos similares constantemente conjugados. Qual é a conseqüência dessa experiência? Ele imediatamente infere a existência de um objeto a partir da aparição de outro. (Investigação, p. 42)

Esse homem agora é capaz de produzir inferências causais. Mas a inclinação a esse ato nada tem a ver com o entendimento. Pois, ele continua absolutamente ignorante quanto aos "poderes secretos" dos objetos. A despeito disso, ele não só pode a realizar inferência causal como é, nas palavras de Hume, "determinado" a fazê-lo117.

Essa determinação não é, evidentemente, da ordem da razão, mas deriva de um princípio natural. Ela se dá de forma inteiramente independente do entendimento. Não por acaso Hume descreve o efeito desse princípio em termos de uma propensão, de uma tendência. Ora, o princípio que produz essa propensão é, como se sabe, o hábito ou costume. Em sua operação sobre a imaginação fundamentam-se as inferências a partir da experiência.

O hábito responde, assim, à pergunta que constituía o limite da análise empreendida por Hume na seção 4, a saber, a questão do fundamento dos raciocínios empíricos. Essa resposta, no entanto, tem um caráter peculiar. Trata-se, como deixa explícito o título da seção 5, de uma "solução cética" dos problemas levantados na seção anterior. Nessa medida, o estatuto do hábito tem de ser explicitado pelo autor. Afinal, o que significa afirmar que trata-se de uma resposta cética? 0 próprio Hume nos indica, pouco antes de apresentar o costume como

\footnotetext{
${ }^{117}$ Sobre essa determinação cf. por ex., TNH, p. 125, onde Hume estabelece o contraste entre o acaso e a relação de causalidade.
} 
resposta o que ele entende por ceticismo. Sem afirmar que a filosofia humiana seja um matiz do ceticismo, vejamos o que ele retém de positivo dessa escola ${ }^{118}$ :

Os acadêmicos não se cansam de falar em dúvida e em suspensão do juízo, no perigo de conclusões apressadas, em confinar as indagações do entendimento a limites bem estreitos e em renunciar todas as especulações que ultrapassam as fronteiras da vida e da prática cotidiana. (Investigação, p. 41)

O acento dessa caracterização não recai, como se poderia esperar, na propensão à dúvida e na negação de qualquer possibilidade de conhecimento. Pelo contrário, se o cético recorre à dúvida é porque a paixão que o domina é o "amor pela verdade". Se o cético coloca em dúvida nossos raciocínios, não é para minar as bases das inferências da vida comum e da ciência. A finalidade da investigação cética é, pelo contrário, evitar tanto a "arrogância da filosofia", quanto a "credulidade supersticiosa". O cético, tal como descrito por Hume, oferece menos perigo à filosofia, à ciência e à vida comum, do que o teólogo e o metafísico. Pois, em vez de minar os fundamentos da especulação, trata-se estabelecer seus justos limites. $O$ que ele faz, ao determinar o território legítimo do raciocínio, é restituir à natureza o lugar que lhe cabe. "A natureza sempre manterá seus direitos e, no final, prevalecerá sobre qualquer raciocínio abstrato" (Investigação, p. 41). O hábito vem a explicitar qual o princípio da natureza humana está envolvido na inferência causal. Ele confere um fundamento a expectativa de

\footnotetext{
${ }^{118} \mathrm{O}$ elogio do ceticismo na Investigação deve ser considerado com cuidado, mediante a leitura de outros textos do autor. Em alguns, como a nota 9 dos Diálogos sobre a Religião Natural, parece haver antes uma crítica que um elogio. Cf. Diálogos, XII, p. 121: "Parece evidente que a disputa entre céticos e dogmáticos é inteiramente verbal ou, pelo menos, que ela só diz respeito aos graus de dúvida e convicção que devemos admitir em relação a todos os raciocínios; habitualmente, tais disputas são no fundo verbais, não permitindo qualquer conclusão precisa.(...) Assim, a única diferença entre essas seitas, se é que merecem esse nome, é que o cético, movido pelo hábito, capricho ou inclinação, insiste mais nas dificuldades, ao passo que o dogmático, pelas mesmas razões, privilegia a necessidade." Aqui, não são as diferenças, e sim as semelhanças entre o cético e o dogmático que são ressaltadas pelo filósofo.
} 
manutenção do curso da natureza. Mesmo assim, isso é realizado dentro de limites precisos, uma vez que o próprio Hume reconhece que a identificação desse princípio não revela as causas últimas da dessa expectativa: "empregando essa palavra [hábito] não pretendemos dar a última razão de tal propensão. Apenas indicamos um princípio da natureza humana que é universalmente reconhecido conhecido por seus efeitos." (Investigação, p.43)

Mas resta que é preciso explicitar como opera esse princípio. A experiência repetida da conjunção de objetos semelhantes impõe uma tendência à imaginação, trazendo ao pensamento a idéia de um deles sempre que o outro se apresentar. Essa conjunção constante afeta a imaginação, sem que a intermediação de nenhum raciocínio ou reflexão ${ }^{119}$.

Essa hipótese parece ser a única capaz de explicar a seguinte dificuldade: por que extraímos de mil casos uma inferência que não somos capazes de tirar de um só? A razão é incapaz de tal variação. As suas conclusões a partir da consideração de um círculo são as mesmas a que chegaria após pesquisar todos os círculos do universo. (Investigação, p.43)

Assim, a única faculdade envolvida aqui é a imaginação, na medida em que ela é afetada pela experiência. No entanto, como mostraram as dúvidas céticas, a simples repetição de seqüências regulares de fenômenos é insuficiente para explicar esse movimento da imaginação.

Hume é enfático quanto a esse ponto no Tratado. Ali, ele faz questão de ressaltar que a mera repetição de percepções não produz nenhuma idéia nova. Não é dessa fonte que vem a crença numa natureza uniforme, tampouco é daí que surgem o nexo causal e a idéia de conexão necessária. Mas, se a mera repetição é incapaz de produzir idéias, o hábito, por outro lado, nos torna sensíveis à repetição e nos 
inclina a esperar que ela continue a ocorrer ${ }^{120}$. Esse ponto é importante, pois fornece pistas sobre o estatuto do costume na filosofia humiana. Enquanto princípio, o hábito não provém da repetição, mas para que possa haver hábitos é preciso que haja experiências repetidas ${ }^{121}$. Isso não significa que a repetição das séries fenomênicas não tenha um papel fundamental. Não por acaso, ao tratar da Probabilidade das Causas Hume mostra que esses hábitos são passíveis de um aperfeiçoamento que depende da repetição freqüente e regular.

Dado que o hábito, que produz a associação de idéias, surge da conjunção freqüente de objetos, ele deve chegar à sua perfeição por graus e adquirir nova força a cada caso que cai sob sua observação. O primeiro caso tem pouca ou nenhuma força, o segundo Ihe acrescenta algo, o terceiro se torna ainda mais sensível: é a passos lentos que nosso juízo se torna completamente seguro. $(T N H, \text { p. 130 })^{122}$

A inclinação produzida pelo hábito nos faz esperar que os padrões observados na experiência passada se repitam no futuro e leva a imaginação a ultrapassar a experiência imediata. Essa inclinação será tanto mais forte quanto mais freqüente e regular for a conjunção entre os objetos.

Por isso, ao tratar da probabilidade das causas, Hume pode expor sem constrangimento a tese segundo a qual é possível que alguém realize uma inferência causal a partir de um único caso. Caso que, vale ressaltar, parece contradizer o papel concedido à experiência repetida

\footnotetext{
${ }^{119}$ Cf. Investigação, p.43.

${ }^{120}$ Cf. Bento Prado Jr., Hume, Freud, Skinner, p. 44: "O que é importante notar aqui, com Deleuze, é que, ao contrário do que pensa o senso comum - e toda a tradição da psicologia intelectualista -, Hume não pensa o hábito como um efeito da repetição das impressões ou das associações entre os estímulos. Pelo contrário, as associações são fruto do hábito que as precede como 'princípio da natureza humana' ".

${ }^{121}$ Como diz Deleuze: "O que é um princípio é o hábito de contrair hábitos." (Empirisme et Subjectivité, p.62)

${ }_{122}$ Essa gradação explica a distinção entre provas e probabilidades empregada no Tratado.
} 
da conjunção constante na produção da inferência causal e da crença na uniformidade da natureza tão enfatizada no argumento da $1^{a}$ Investigação.

É verdade que nada é mais comum que pessoas de grande conhecimento com uma experiência apenas imperfeita de eventos particulares, o que naturalmente só produz um hábito e transição imperfeito. Mas deve-se notar que a mente, tendo observado outras conexões de causas e efeitos, confere nova força a seu raciocínio a partir dessa observação, tornando-se capaz de construir um argumento baseada num único experimento que seja devidamente preparado e examinado. (TNH, p. 130)

O que ocorre é que do ponto de vista de sua constituição o vínculo entre causa e efeito depende da repetição e do hábito, segundo a maneira acima descrita. Esses elementos são indispensáveis para a investigação acerca da gênese do nexo causal. E é justamente a constituição ou o fundamento desse vínculo que Hume se propõe a investigar nas Dúvidas Céticas e na solução Cética. Todavia, não é absurdo que, uma vez acostumado a realizar a inferência causal e tendo se consolidado a crença na regularidade da natureza, um homem seja ser capaz de estabelecer a relação causal a partir de um único caso.

Mesmo nesse caso, a tendência gerada pelo hábito produz a crença na manutenção da uniformidade da natureza, levando a imaginação a conceber a idéia do efeito sempre que estiver diante da causa e vice-versa ${ }^{123}$. É devido a tal inclinação que somos capazes de ultrapassar a imediatez dos casos dados na experiência e a realizar a inferência causal. Não há exagero em afirmar que o hábito é que possibilita a própria razão experimental, pois é esse princípio que

\footnotetext{
${ }^{123}$ Visto sob esta perspectiva o hábito é um princípio da natureza humana que explica o movimento da imaginação ao associar a causa e o efeito. Nesta medida, não cabe tentar explicá-lo. Tentar fazê-lo, seria ultrapassar aqueles limites admitidos quando da adoção do método experimental, pois, o esforço último da filosofia, como Hume enfatizava na introdução do Tratado, é meramente descobrir alguns princípios gerais. Cf. TNH, p.xvii; Investigação, p.30.
} 
possibilita que sejamos afetados pela conjunção constante de tal forma que nos vemos determinados a pensar o efeito quando estamos diante da causa e vice-versa. O hábito faz-nos esperar que as conjunções de objetos observados na experiência passada se repitam no futuro, criando assim uma certa crença na regularidade e na manutenção do curso da natureza. ${ }^{124}$

\section{IV}

Esse conceito de causalidade fornece os instrumentos para que Hume possa pensar a gênese da idéia da conexão necessária. A relação de causa e efeito passa a ser concebida como a união de dois objetos distintos e sem qualquer relação interna entre si. Essa união só ocorre devido à ação de um princípio que afeta a nossa imaginação fazendo com que ela passe de um objeto presente à concepção e à crença em seu par habitual. Na análise de Hume a idéia de conexão necessária vai aos poucos perdendo legitimidade e cede espaço à conjunção constante e ao hábito. O exame de sua origem é antes resultado de uma recusa do conceito de causa da tradição moderna do que a mera clarificação do mesmo.

A afirmação da necessidade da relação causal é tributária de uma determinada concepção da causação que atribui a um objeto a eficácia e o poder de produzir um outro. Como a Investigação não deixa de notar, no quadro formado por essa tradição o termo causalidade recobre uma série de termos obscuros e noções implícitas. Pensada em termos de produtividade, a relação de causalidade remete-nos às idéias obscuras e

\footnotetext{
${ }^{124}$ Cf. TNH, p.265: "A experiência é um princípio que me instrui a respeito das várias conjunções de objetos do passado. O hábito é um outro princípio que me determina a esperar o mesmo para o futuro. E ambos, conspirando para operar na imaginação, fazem-me formar certas idéias de maneira mais intensa e viva do que outras destituídas dessas mesmas vantagens."
} 
incertas de poder, força e energia. A tarefa a que Hume se propõe consiste justamente em elucidar essas noções.

Assim, no Tratado e na Investigação, as diversas feições assumidas pela idéia de poder causal na filosofia moderna vão sendo submetidas ao crivo do princípio do empirismo.

Alguns afirmam que os corpos operam por sua forma substancial; outros, que pelos seus acidentes e pelas suas qualidades; muitos dizem que pela sua matéria e forma, alguns que pela sua forma e acidentes; outros ainda, que por certas virtudes e faculdades distintas de tudo isto. ( $T N H$, p.158)

Todas essas maneiras de conceber o poder e a eficácia das causas são confusas e obscuras e não resistem à aplicação do critério proposto por Hume.

Quando examinamos os objetos fora de nós e consideramos a operação das causas não somos capazes, num único caso sequer, de descobrir qualquer poder ou conexão necessária, uma qualidade que ligue o efeito à causa e torne um a conseqüência infalível do outro. (Investigação, p. 63)

A recusa da idéia de conexão necessária é conseqüência da nova noção de causalidade. Afinal, uma vez que a experiência não nos revela nenhuma qualidade que indique a união indissolúvel da causa e do efeito, toda aspiração a colocar o princípio da causação na substância corpórea está fora de questão.

Se explicar a gênese do poder é um problema para o empirista, que dizer da situação em que se encontra o filósofo cartesiano? Tomese, por exemplo, o embaraço em que se enreda Malebranche, devido à doutrina do ocasionalismo. No Tratado e na Investigação Hume critica 
duramente o filósofo, que parece ter levado a noção cartesiana de causa ao absurdo ${ }^{125}$.

Os cartesianos em particular, tendo estabelecido que estamos perfeitamente familiarizados com a essência da matéria, inferiram muito naturalmente que ela não é dotada de eficácia, e que lhe é impossível comunicar movimento por si mesma ou quaisquer outros dos efeitos que Ihe atribuímos. (Tratado, p.159)

Partindo da concepção dos corpos como pura extensão, os cartesianos os esvaziariam de qualquer eficácia ou poder. No entanto, a causalidade física demanda uma explicação. A solução de Malebranche, que continua a pensar a causalidade poder produtivo, será postular Deus como causa única da existência e da ação dos seres corpóreos ${ }^{126}$. Se, como observa Hume, essa doutrina não se sustenta nem que se recorra à ficção das idéias inatas, o que dizer de seu estatuto numa filosofia que situa a origem de todas as idéias em impressões dos sentidos? Com efeito, já que nenhum dos seres corpóreos possui poder algum, aqui $o$ ocasionalista jamais poderia conceber quaisquer idéias dos poderes da divindade. De onde ele tiraria a idéia de poder já que ela não é dada por nenhuma qualidade sensível? Na Investigação Hume não poupará Malebranche de seu sarcasmo e afirmará que, com doutrinas como a dele, adentramos no "país das fadas".

Essas questões deveriam ser suficientes para afastar a fantasia ocasionalista. Pois, que não saibamos aonde reside o poder dos objetos empíricos, não implica em que possamos substituí-lo por um outro poder que também desconhecemos.

\footnotetext{
125 Como comenta Hume na Investigação, embora Descartes não tenha chegado a formular o ocasionalismo ele forneceu os bases para esta doutrina, ou, como diz Hume, ele o "insinuou". Cf. Investigação, p.73.

126 Sobre as críticas de Hume ao ocasionalismo cf. Norton, David Hume, Common-Sense Moralist, Sceptical Metaphysician, p.205.
} 
Se toda idéia é derivada de uma impressão, a idéia de uma deidade deve proceder da mesma origem. Mas, se nenhuma impressão, de sensação ou de reflexão, implica qualquer força ou eficácia, é igualmente impossível descobrir ou mesmo imaginar qualquer princípio ativo na Divindade. $(T N H, \text { p.160 })^{127}$

A postulação da eficácia divina demanda que ultrapassemos o domínio legítimo da experiência, construindo hipóteses sobre suposições infundadas. Não por acaso, Hume se refere a essa tentativa em termos que beiram o escárnio:

Embora possamos nos gabar de que estamos sendo guiados, a cada passo que damos, por uma espécie de verossimilhança e experiência, podemos estar seguros de que essa experiência fantasiosa não tem autoridade quando a aplicamos a assuntos que se situam inteiramente fora da esfera da experiência. (Investigação, p.63)

As longas cadeias de raciocínio empregadas pelo ocasionalista - por mais verossímeis que pareçam - ultrapassam os limites da experiência e se reduzem à mera fantasia.

No entanto, Hume tem de refutar uma segunda hipótese que aparentemente se constrói em termos que poderiam ser aceitos em sua filosofia.

Dado que os objetos externos, da maneira como nos aparecem, não nos dão, por sua operação em casos particulares, qualquer idéia de poder ou conexão necessária, resta ver se essa idéia não seria derivada da reflexão sobre as operações de nossas próprias mentes e copiada de uma impressão interna. (Investigação, p. 64)

Trata-se de examinar a hipótese segundo a qual a conexão necessária derivaria de uma impressão de reflexão que supostamente tem sua origem no comando que a vontade exerce sobre o corpo. Quando movo

${ }^{127}$ Cf. Investigação, pp. 72-73. 
meus membros, realizo um ato consciente que me revelaria o poder que possuo sobre meu corpo ${ }^{128}$. O problema aqui é que a união entre corpo e alma é, ela mesma, demasiado obscura. O fato de que possamos perceber que a um comando da vontade segue-se um movimento do corpo não nos esclarece nada a respeito da relação entre estes dois termos. Precisaríamos conhecer a natureza destas duas substâncias e de sua união para que pudéssemos formar a idéia do poder de um sobre o outro. Em segundo lugar, a ação da vontade está longe de ser infalível. Diversos órgãos que não se encontram sob a sua influência. Esse fenômeno seria plenamente compreensível, se tivéssemos uma idéia do poder da vontade. "Por que a vontade tem influência sobre os dedos e a língua, e não sobre o coração ou o fígado?" (Investigação, p. 65). O fato, porém, é que não temos consciência alguma de nosso poder sobre o corpo. É freqüente, como comenta Hume, que um homem repentinamente acometido por paralisia tente mover o membro paralisado. Ora, o homem neste estado é supostamente tão consciente de seu poder sobre seu corpo quanto um homem saudável, no entanto, ele insiste em tentar realizar uma ação que the é impossível levar ao cabo. Por último, Hume evoca a idéia dos espíritos animais para mostrar que a passagem entre o ato da vontade e o ato do corpo é intermediado por uma série de processos que desconhecemos. Se tivéssemos uma consciência real desta relação entre a vontade o corpo, estes eventos intermediários envolvidos no processo da ação seriam igualmente conscientes. Essa consciência só pode ser ficção, pois, se fôssemos de fato conscientes da eficácia da vontade sobre o corpo não enganaríamos quanto a nossa capacidade de atuar sobre ele ou quanto aos processos e limitações que envolvem esta ação.

\footnotetext{
128 Note-se que no Tratado a hipótese da gênese da idéia de conexão necessária nas impressões de reflexão relativas à ação da vontade sobre o corpo é posta apenas no Apêndice. Cf. TNH, apêndice, pp. 632-633.
} 
Mas seria possível objetar que, ainda que não conheçamos a relação alma e corpo, somos plenamente conscientes do poder que a vontade exerce sobre nossas idéias, comandando sua concepção e fixando a mente em sua contemplação. A objeção é passível, porém, da mesma refutação. E o resultado desse último momento da argumentação é que a suposta consciência que temos da eficácia da vontade está baseada na conjunção constante entre seus comandos e os efeitos esperados. E, como já vimos:

A repetição de casos perfeitamente similares não pode produzir uma idéia original diferente da que se encontra em qualquer caso particular - como aliás já foi observado e evidentemente se segue do princípio fundamental segundo o qual todas as idéias são copiadas de impressões. (TNH, p.163)

A ação da vontade é conhecida por experiência, e a experiência nos indica apenas que dois eventos se sucedem com regularidade.

Em todos os casos analisados por Hume no Tratado e na $1^{\text {a }}$ Investigação o resultado é o mesmo: aplicado com rigor, o princípio do empirismo torna patente a inexistência de uma impressão sensível da qual o poder das causa possa ser derivado. Em nenhum das hipóteses aventadas a experiência revela uma impressão da qual a idéia de conexão necessária pudesse ser derivada.

Todavia, resta uma última possibilidade. Na inferência causal somos levados a crer na existência de um objeto da espécie A sempre que estivermos diante de um objeto da espécie $\mathrm{B}$ devido à conjunção constante na qual os objetos de tais espécies sempre se apresentaram a nós. É certo que, sendo ambos distintos e separáveis entre si, de tal conjunção não se pode extrair a conclusão de nenhuma espécie de ligação interna entre eles; mas, ainda assim, somos determinados a realizar a inferência de um ao outro. Por meio do hábito, a repetição da experiência afeta a imaginação fazendo-a ligar os conteúdos que se 
seguem regularmente na sucessão dos eventos observáveis. A idéia de conexão necessária é um efeito dessa afeç̧ão, ela é conseqüência do hábito e da constância dos fenômenos empíricos: "essa conexão que nós sentimos na mente, esta transição costumeira da imaginação de um objeto para o seu acompanhante usual, é o sentimento a partir do qual nos formamos a idéia de poder ou conexão necessária." (Investigação, p. 75) Assim, o princípio que está na base da razão experimental não é, ele mesmo, um princípio racional. Ele é, isto sim, relativo ao sentimento. Sem explicar por quê dois objetos distintos se ligariam na imaginação a filosofia de Hume pretende apenas legitimar essa operação analisando o mecanismo que a engendra ${ }^{129}$.

A conexão costumeira afeta a imaginação e a impressão de reflexão que ela produz é que leva, numa primeira instância, tal faculdade a ligar os conteúdos empíricos. Numa segunda instância, produz-se a idéia de conexão necessária presente na relação filosófica de causalidade. O processo tem dois momentos: o momento da concepção da idéia do objeto ausente e, em segundo lugar, o da produção da idéia de conexão necessária. A concepção da idéia do objeto através da relação natural de causalidade precede a relação filosófica e a produção da idéia de conexão necessária. A mediação entre ambas reside na ação do hábito sobre a imaginação. Assim, pela definição de causalidade em seu modo filosófico estabelecemos que a causa é "um objeto seguido de outro, quando todos os objetos semelhantes ao primeiro são seguidos por objetos semelhantes ao segundo. Ou, em outras palavras, se o primeiro objeto não houvesse existido, o segundo nunca haveria existido." (Investigação, p.76) ${ }^{130}$ Esse vínculo entre a causa e o efeito não é nem dado pelas qualidades

\footnotetext{
${ }^{129}$ Como afirma Malherbe: "Fazer do hábito um princípio de inteligibilidade é, portanto, falsear a análise humiana. Ele causa a inferência, mas a essência da causa resta obscura, e não é dele que se tira o efeito." (La Philosophie Empiriste de David Hume, p. 124)

${ }^{130}$ Cf. TNH, p.170.
} 
sensíveis do objeto, nem obtido pela razão abstrata. Ele é um efeito da relação natural, calcada no hábito, que projetamos nos objetos dos sentidos. A concepção da causalidade enquanto relação filosófica só é possível em virtude da experiência da repetição de casos semelhantes. A relação natural ${ }^{131}$ precede, portanto, a filosófica. Nessa medida, não espanta que a inferência causal possa ser descrita em termos de tendência, propensão, inclinação ou mesmo instinto. Não por acaso, ao investigar se existe algo como a razão nos animais, Hume conclui que

o próprio raciocínio experimental, que possuímos em comum com as bestas e do qual depende toda a condução da vida, é tão somente uma espécie de instinto ou poder mecânico que atua incógnito sobre nós e que em suas principais operações não é dirigido por nenhuma daquelas relações ou comparações de idéias que são os objetos próprios de nossas faculdades intelectuais. (Investigação, p. 108)

A relação de causalidade não se fundamenta, portanto, numa conexão necessária entre a causa e o efeito a ser descoberta pela razão, seja a priori, seja a posteriori. A análise de Hume denuncia que a idéia metafísica de necessidade advém de uma inclinação de nossa natureza, que estende indevidamente as relações estabelecidas na imaginação para o domínio dos objetos sensíveis. Devido a tal tendência é que somos levados à ilusão de que o efeito se segue necessariamente à causa. Necessidade, dirá Hume no Tratado, "(...) é apenas aquela determinação do pensamento de passar das causas aos efeitos e dos efeitos às causas, de acordo com sua união observada na experiência." ( $T N H$, p.166) Esse processo é da esfera do sentimento e não da razão. Nós sentimos a transição costumeira entre nossas percepções e transferimos esta conexão, legítima apenas no âmbito da imaginação,

\footnotetext{
${ }^{131}$ Cf. Investigação, P.76: "um objeto seguido de outro, e cuja aparição sempre transporta o pensamento para aquele outro."
} 
para os próprios objetos dos sentidos, dando assim origem às noções metafísicas de eficácia das causas, poder, conexão necessária, e etc. Em suma: o mesmo princípio que possibilita a inferência causal dá origem, mediante a afecção da imaginação, à crença em uma ficção. Conclusão de certo modo escandalosa para o racionalismo clássico, pois, desse ponto de vista, a noção moderna de causa é reduzida ao mero resultado de uma operação da fantasia, não expressando nenhuma relação real entre os objetos da experiência.

O comentário da idéia de conexão necessária ocupa um lugar extremamente relevante para o pensamento de Hume. Ele expõe uma conseqüência importante da concepção humiana de causalidade. A análise da relação causal revela uma propensão da natureza humana a criar ficções e estender indevidamente as relações que se estabelecem na imaginação para o domínio dos objetos sensíveis. Devido a tal tendência é que somos levados à ilusão de que o efeito se segue necessariamente à causa ${ }^{132}$. Nós sentimos a transição costumeira entre as nossas percepções e transferimos essa conexão que é legítima no âmbito da imaginação para o campo dos objetos dos sentidos ${ }^{133}$, dando origem às noções metafísicas de eficácia das causas, poder, conexão necessária, e etc. Desse ponto de vista, poderíamos dizer que a noção metafísica de causa é, portanto, o resultado de uma operação da imaginação e não implica nenhuma relação intrínseca dos objetos da experiência. O exame da idéia de conexão necessária não só desvenda o mecanismo a partir do qual forjamos a ficção de uma ligação essencial entre os objetos da experiência, mas põe em xeque uma das principais figuras da epistème moderna.

\footnotetext{
${ }^{132}$ Sobre a noção correta de necessidade vide $T N H$, p. 166: "Ou não temos idéia de necessidade, ou necessidade é tão somente uma determinação do pensamento a passar das causas aos efeitos e dos efeitos às causas, de acordo com sua união, atestada pela experiência."

133 Cf. Investigação, pp.77-78, nota; TNH, p. 168.
} 
Mais que isso, tributário da adesão ao princípio da diferença e separação, o comentário humiano da causalidade e da conexão necessária explicita a rejeição da tese racionalista segundo a qual a inteligibilidade da experiência repousaria na possibilidade de descobrir vínculos essenciais entre seus objetos. Essa hipótese, a bem da verdade, estava excluída desde o momento em que Hume tomara o partido da ontologia da descontinuidade, e ressaltara a distinção entre a causa e o efeito como fato central para o exame. Desde então, o vínculo entre a causa e seu efeito não poderia mais ser comentado nem a partir de um raciocínio a priori, nem a partir das qualidades sensíveis dos objetos. Embora o instrumento de análise utilizado por Hume na investigação acerca da conexão necessária idéia seja o princípio do empirismo, a partir do momento em que as relações entre nossas percepções eram comentadas nos termos dessa ontologia estava vedado o acesso da mente a qualquer relação interna entre os objetos da experiência.

\section{V}

É natural que essa nova concepção de causalidade suscite a temática da crença. Com efeito, se não há lugar para a "necessidade absoluta" nos raciocínios causais, o índice de realidade de uma proposição torna-se uma incógnita a ser elucidada. Por que razão devo assentir à proposição segundo a qual o choque de duas bolas de bilhar deve traduzir-se em movimento? Por que não afirmar seu contrário, uma vez que no território das questões de fato eles não são necessariamente excludentes e podem ser perfeitamente concebidos como existentes? Desde a expulsão do conhecimento de demonstrativo do território dos fatos é preciso investigar o que me leva a conceder a certas idéias título de realidade e considerar tantas outras como meras 
ficções. Nos termos de do Tratado cabe perguntar: "Em consiste a diferença entre incredulidade e crença?"

Assim, deve-se indagar com o filósofo escocês, por que dou meu assentimento "a uma idéia de Roma, cidade que não vejo nem recordo", mas considero como fictícia a idéia de um cavalo alado? Ora, como insiste o Hume em mais de uma passagem, não há nenhuma diferença de natureza entre elas. E quando as concebo nada me indica que uma existe e a outra não. Com efeito, dirá Hume no Tratado:

A idéia se identifica exatamente à idéia daquilo que concebemos como existente. Refletir sobre algo simplesmente e refletir sobre ele como sobre uma existência são dois atos que em nada diferem um do outro. (...) Tudo o que concebemos, nós o concebemos como existente. (TNH, pp.66-67)

A resposta de Hume a esse problema é conhecida. Não há uma distinção de natureza entre ficção e convicção, mas na maneira como elas são concebidas. Essa diferença diz respeito à força e à vivacidade com a qual essas idéias afetam a imaginação. É devido à intensidade dessas duas qualidades que se produz o assentimento a uma idéia qualquer ${ }^{134}$.

A crença é, antes de tudo, um termo que se refere à afecção da imaginação por uma idéia. E a maneira pela qual realizamos uma inferência causal indica a via para compreendermos como essa convicção se produz na imaginação. Os raciocínios causais levam-nos a crer na existência de objetos que extrapolam os dados imediatos da experiência, mas sempre têm por termo último uma impressão da memória ou dos sentidos. A crença causal é, assim, uma "idéia viva relacionada, ou associada, a uma impressão presente."Resposta aparentemente apaziguadora, que pode levar o leitor a pensar que a

${ }^{134}$ Cf. TNH, p. 96: "Assim, como a crença nada faz além de variar a maneira pela qual concebemos qualquer objeto, ela pode apenas dotar nossas idéias de uma força e vivacidade adicional." 
filosofia humiana está a propor uma solução que envolva a formulação de um critério de demarcação que nos assegura da diferença entre realidade e da ficção. Com efeito, Hume é empirista, e nada mais razoável do que esperar que ele fizesse das impressões sensíveis o fiel da balança.

O gesto de Hume tem, porém, um outro sentido, talvez mais radical e menos tranquilizador. Em vez de propor um critério como esse, a filosofia humiana parece precisamente recusar uma dicotomia rígida entre esses termos ${ }^{135}$. Com efeito, a relação de causal é apenas um dos modos de produção da crença. Há outros princípios e circunstâncias que avivam as idéias e afetam a imaginação, produzindo uma tendência ao assentimento. A educação, as paixões a poesia e a eloqüência vêm juntar-se à ocorrência de uma impressão presente no rol dos princípios produtores de convicção. As paixões contribuem para aumentar os graus de força e vivacidade das idéias. Assim,

Um covarde, cujo medo é facilmente despertado, prontamente dá seu assentimento a todo relato de perigo com o qual se depara; assim como uma pessoa de disposição pesarosa e melancólica é muito crédula de qualquer coisa que alimente sua paixão predominante. (TNH, p.120)

$\mathrm{Na}$ educação, por outro lado, a repetição freqüente fixa idéias na imaginação e suscita a crença. A poesia e a eloqüência, por sua vez, são usos da linguagem que animam e fortalecem as idéias, tanto por sua semelhança em relação às nossas inferências empíricas, quanto pelas paixões que excitam: "é difícil para nós conter o assentimento àquilo que nos é pintado com todas as cores da eloqüência; e a vivacidade produzida pela fantasia é muitas vezes maior que aquela que surge do

\footnotetext{
135 Segundo nos parece, o comentário Hume visa explicar a produção da convicção dentro do espírito proposto no projeto da constituição de uma ciência da natureza humana. Desse modo, a análise da crença requer o exame da gênese desse sentimento, bem como da operação dos princípios.
} 
costume e da experiência." (TNH, p.123) Por último, a associação por semelhança e contigüidade possui a capacidade de fortalecer nossa concepção de uma idéia quando a associam a uma impressão correspondente ${ }^{136}$.

Se há tantos princípios produtores de crença - alguns deles flagrantemente associados à fantasia - qual o sentido dessa diferenciação? Note-se que Hume situa o ponto de dessemelhança entre idéias reais e fictícias justamente nas mesmas qualidades que nos fazem distinguir impressões e idéias. É devido a graus de força (force) e vivacidade (vivacity) que se concede, ou não, assentimento. "Assim, aquela crença nada faz além de variar a maneira (manner) pela qual concebemos qualquer objeto, ela pode apenas dotar nossas idéias de uma força e vivacidade adicionais." (TNH, p.96) Não há nenhum critério racional que nos autorize a distinguir ficção de conviç̧ão, é pela influência dos graus de força e vivacidade das idéias que estabelecemos essa diferença. A distinção entre a ficção e a convicção não se funda numa distinção de natureza, mas numa diferença de graus de certas qualidades que afetam a mente $\mathrm{e}^{137}$.

Essa solução desloca a questão da evidência de nossos juízos de existência do âmbito da razão para o âmbito do sentimento ${ }^{138}$. É por isso, que a crença não poderá ser definida, mas exemplificada e descrita. Não se trata de inexatidão ou imprecisão do autor. Afinal, o sentimento produzido por essas duas qualidades é universalmente experimentado por todos os homens e, nessa medida, inequívoco. Assim, no que tange ao sentimento, a noção de crença é perfeitamente clara: "crença é o nome verdadeiro e apropriado deste sentimento (feeling) e ninguém jamais se confunde quanto ao significado deste termo. Pois, todo homem

\footnotetext{
${ }^{136}$ Cf. TNH, I, 3, 8; Investigação, V, 2.

137 Cf. TNH, Apêndice, p. 628: "Eu concluo, por uma indução que me parece muito evidente, que uma opinião ou crença não é senão uma idéia que é diferente da ficção não pela natureza ou pela ordem de suas partes, mas pela maneira (manner) de ser concebida."
} 
está consciente a todo momento do sentimento por ele representado." (Investigação, pp. 48-49)

Essa conclusão demanda, porém, certa cautela. Ao mostrar que a crença se produz pela eloqüência, pelas paixões e pela educação, Hume não diminui a prevalência da convicção baseada na presença de uma impressão. Ora, embora afirme que esses princípios e operações possam ser capazes de causar um acréscimo de força e vivacidade às idéias, a impressão sensível sempre produz uma convicção mais forte. A consideração de que a eloqüência, as paixões, a educação e os princípios de associação produzem convicção, serve para ressaltar que a diferença entre a convicção derivada da retórica, por exemplo, e a convicção baseada na experiência é uma diferença de graus ${ }^{139}$. Uma vez que ficção e convicção se distinguem uma da outra por certas qualidades sentidas pelo espírito, o que haverá é uma gradação que vai da convicção mais forte, produzida pela ação da experiência sobre a imaginação, à pura ficção ${ }^{140}$.

\section{VI}

A teoria da crença é coerente com os pontos de partida assumidos por Hume na análise da causalidade. A partir do momento em que não há mais relações internas e necessárias entre os objetos do campo das questões de fato a crença surge como questão e a resposta através da idéia de convicção racional parece fora de propósito ${ }^{141}$. Excluída essa

\footnotetext{
138 Cf. por exemplo, Investigação, p.48.

139 Cf. TNH, apêndice, p.631.

140 Sobre a conotação anti-cartesiana da doutrina da crença Cf. Ribeiro de Moura, David Hume para além da Epistemologia, In: Racionalidade e Crise; Norton, David Hume, Common-Sense Moralist, Sceptical Metaphysician, nota 18, p.202.

${ }^{141}$ Não por acaso, conclusão da análise da crença suscitou censuras dos comentadores filiados à tradição filosófica do neopositivismo. Com efeito, interessados em elaborar uma epistemologia que barrasse a metafísica esses autores não poderiam corroborar uma argumentação que não resultasse na demarcação rígida das fronteiras da ficção e da convicção, assegurando posição privilegiada para a ciência positiva. Assim, a concepção humiana da causalidade foi louvada como um poderoso golpe desferido contra a metafísica, mas a crença foi considerada como um momento em que o rigor filosófico por Hume. No comentário humiano da crença, o filósofo
} 
possibilidade, a crença será formulada a partir da análise das afecções que determinam a mente. Através do sentimento que se produz a partir delas somos compelidos a conceder estatuto de realidade a certas idéias e assim, no caso da causalidade, somos capazes de completar o sistema da experiência imediatamente dada, acrescentando-lhe as idéias inferidas causalmente. Nessa medida, a crença e a causalidade são conceitos complementares e temas que suscitam um ao outro.

Ambas são passos necessários de um processo que se descreve desde o seu início no Tratado e na Investigação. Além de partes fundamentais na determinação do estatuto do conhecimento das questões de fato, do ponto de vista da geografia mental de Hume a causalidade e a crença são etapas necessárias para descrever o processo através do qual a imaginação torna-se entendimento. Em outras palavras, trata-se de explicar, de um lado, como uma mera coleção de percepções, a imaginação, torna-se entendimento, e, por outro lado, como esta faculdade é capaz de dotar de unidade percepções que são por natureza distintas e sem relação entre si. O primeiro momento desse processo é levado ao cabo pelas relações naturais ou princípios associativos. Esses, como vimos, ordenam a atividade da imaginação tornando-a regular e regrada. Agindo sobre a imaginação, tais princípios não dão somente a regra para sua atividade, mas contribuem para a ordenação e sistematização da diversidade das percepções.

É justamente a ação da relação natural de causalidade sobre a imaginação que cumpre o passo seguinte. O processo de inferência causal estabelece conexões entre objetos distintos, conexões essas que

rigoroso que passou a noção de causa e efeito pelo crivo do empirismo, depurando-a de toda sua carga metafísica, teria dado lugar ao "psicólogo experimental", para usarmos a expressão de James Noxon. Assim, Hume teria fracassado em sua tentativa de determinar um princípio de demarcação que separasse ficção de conviç̧ão, "incredulidade e crença". Sobre isso, cf. Flew, Hume's Philosophy of Belief, pp.96-101; Noxon, Hume's Philosophical Development, pp. 161164; Passmore, Hume's Intentions, pp.61-64. 
fortes o suficiente para nos inclinar a admitir a existência de um objeto não foi imediatamente dado aos sentidos. Dessa forma, a relação natural de causalidade produz uma nova ordenação dos dados sensíveis, acrescentando a esses um segundo sistema de realidades, possibilitando a ultrapassagem dos dados imediatos dos sentidos ${ }^{142}$. Por outro lado, a relação de causalidade, enquanto relação filosófica, refletida pela imaginação, nos permite formular regras gerais a respeito do comportamento dos fenômenos.

Ora, em razão da adoção do princípio da diferença e separação, a unidade toda deste sistema é dada externamente pela própria relação causal. Esse caráter extrínseco da conexão entre os objetos impõe a necessidade da crença. Contudo, o papel da noção de crença não se reduz ao de responder uma pergunta que se coloca necessariamente no decorrer da explicação da inferência causal. A crença é um ato necessário e natural da mente humana para que a própria causalidade possa ser eficaz neste processo de ordenação da diversidade sensível. Talvez não seja exagero dizer que é na medida em que a causalidade produz crença, que se torna possível efetuar uma tal ordenação dos fenômenos. Pois, é por esse sentimento que atribuímos o estatuto de realidade às idéias inferidas pelos raciocínios causais. Sem a sua concorrência a conjunção constante não seria traduzida de forma a anexar aquele segundo sistema de realidades ao sistema dado pela memória e pelos sentidos.

Todavia, esse processo de produção da ordem não termina aqui. Embora as relações naturais tornem regrada a atividade da imaginação na associação de idéias, essa faculdade tende a criar ficções como, por

\footnotetext{
${ }^{142}$ Como mostra Deleuze a ordenação efetuada pela causalidade é também uma síntese do tempo, fundamental na constituição do sujeito. A inferência e a crença causais, através do hábito, ligam o passado, o presente e o futuro: "O hábito é a raiz constitutiva do sujeito, e o sujeito é na sua raiz a síntese do tempo, a síntese do presente e do passado com vistas ao porvir." (Empirisme et Subjectivité, p. 101)
} 
exemplo, a idéia de conexão necessária que analisamos acima. Apesar da influência dos princípios associativos, a imaginação mantém algo de sua liberdade e projeta indevidamente, no caso da idéia de conexão necessária, as relações que unem nossas percepções sobre os objetos. Mais que isso, pode-se dizer que a idéia de conexão necessária é um efeito da ação da causalidade e do hábito sobre essa faculdade. Pois, como vimos, em sua base está uma impressão de reflexão causada pelo costume. Tal impressão de reflexão gera na imaginação uma idéia que nos leva a afirmar que existe um vínculo interno, um nexo de natureza, entre a causa e o efeito e que nos faz esquecer que a relação de causa e efeito - como, aliás, todas as outras - é uma relação externa ao seus termos ${ }^{143}$. Essas razões fazem da conexão necessária uma ilusão inevitável, pois, ela é resultado da ação dos princípios de associação e de uma tendência natural da imaginação. Todavia, ela é passível de ser corrigida por uma crítica empirista, como a que é realizada no Tratado e na Investigação. Através de uma análise empirista podemos traçar sua gênese e restituir seu verdadeiro significado.

\footnotetext{
143 Veja-se, por exemplo, o comentário de Hume a este respeito, quando da análise da questão da identidade pessoal: "Poderíamos decidir facilmente esta questão se retomássemos o que já foi amplamente provado: que o entendimento nunca observa qualquer conexão real os objetos e que mesmo a união de causa e efeito, se examinada com precisão, resume-se (resolves itself) a uma associação costumeira de idéias." (TNH, pp. 259-260)
} 


\section{Capítulo IV - Ilusões Naturais e Ficções Metafísicas}

\section{I}

O comentário humiano da causalidade expõe a imaginação (imagination) enquanto fantasia (fancy). A análise da relação causal revela que a idéia metafísica de necessidade advém de uma impressão de reflexão, levando-nos a estender indevidamente relações que, a rigor, só existem na imaginação. Devido a essa tendência produzimos a ilusão de que o efeito se segue necessariamente à causa. Assim, a necessidade, dirá Hume no Tratado, "(...) é aquela determinação do pensamento de passar das causas aos efeitos e dos efeitos às causas, de acordo com sua união observada na experiência." (TNH, p.166) Nada disso nos indica a existência de uma relação intrínseca ou essencial entre causa e efeito. Mesmo assim, forjamos uma ligação desse gênero. Sentimos a transição costumeira de nossas percepções e transferimos essa conexão, legítima apenas no âmbito da imaginação, para o campo dos objetos dos sentidos ${ }^{144}$, dando origem às noções metafísicas de eficácia das causas, poder, conexão necessária, e etc. Em suma: o mesmo princípio que possibilita a inferência causal pode, devido ao modo como afeta a imaginação, dar origem à crença em uma ficção. Revela-se assim, o aspecto, por assim dizer, fantasista da imaginação. Não por acaso, dependendo das operações que realiza, essa faculdade será chamada de imaginação ou de fantasia.

O exame da causalidade fornece assim subsídios para uma extensa crítica da metafísica, que se realiza em paralelo com a análise de uma série de ilusões naturais. É após a discussão acerca da relação

\footnotetext{
${ }^{144}$ Cf. Investigação, nota 1, pp.77-78: "No que concerne as energias que se exercem sem que anexemos a elas qualquer idéia de comunicação do movimento, consideramos somente a conjunção constante entre os eventos, por nós experimentada. E, como sentimos uma conexão costumeira entre as idéias, transferimos esse sentimento (feeling) para os objetos. Pois nada é mais comum do que aplicar aos corpos externos as sensações internas que eles ocasionam." Cf. também $T N H$, p. 168.
} 
de causa e efeito que o filósofo examina as diversas ilusões que deram origem a noções em torno das quais a metafísica articulou-se. Misto de história da filosofia e critica da metafísica, a parte 4 do livro I do Tratado e a seção XII da Investigação são também parte da ciência do homem, pois mostram como, a partir de princípios da natureza humana, a imaginação produz ilusões naturais que servirão de base para as ficções da metafísica antiga e moderna.

A referida seção do Tratado percorre as principais etapas dessa breve história crítica da filosofia. Assim, em primeiro lugar Hume vai analisar, na seção II, a crença na existência independente e identidade dos corpos. A seção III mostra como, diante das dificuldades engendradas por essa fiç̧ão, os antigos formularam as noções de qualidade oculta e forma substancial, enredando-se em obscuridades ainda maiores. As filosofias modernas baniram essas noções, mas, como demonstra a análise realizada na seção IV, produziram novos embaraços ao distinguir qualidades primárias de secundárias. A seção $\mathrm{V}$ mostra ao leitor que a mesma dificuldade que nos acompanha nas teorias acerca dos objetos sensíveis impõe-se quando nos voltamos para a mente e seus objetos. A tese de uma substância imaterial, simples e independente revela-se problemática, pois, não há impressão correspondente à alma imaterial. Em todos esses casos, o problema reside, em grande parte, na atribuição de uma identidade e uma continuidade àquilo que não passa de uma coleção de percepções voláteis que podem estar em constante mudança, diagnóstico que, digase de passagem, já se insinuava desde o comentário acerca da substância na primeira parte do Tratado. ${ }^{145}$ Examinadas do ponto de vista do princípio de diferença e separação, as categorias da metafísica serão passadas em revista, uma a uma, até que se chegue a própria

${ }^{145}$ Cf. TNH, pp.15-17. 
noção de identidade pessoal - clímax desse trabalho de etiologia e desmanche do discurso metafísico.

Mas o movimento da análise de Hume não estanca aqui. Como ocorria no comentário da relação de causa e efeito, não se trata apenas de demonstrar que tais conceitos não resistem à análise empirista. Também nesse caso, o exame avança no sentido de descobrir a gênese dessas fiç̧ões e da determinação dessa origem de acordo com os princípios da ciência da natureza humana. Assim, as duas principais fiç̧ões que dão origem às noções metafísicas de substância, forma substancial, qualidades primárias e secundárias, e da alma - a crença nas existências externas e na idéia de identidade pessoal - serão objeto de uma explicação que visa esclarecer seu modo de produção, a partir da natureza humana. Revela-se, então, o mecanismo através do qual a imaginação se exerce como fantasia atribuindo aos objetos uma existência contínua e independente da percepção a qual uma análise estritamente empirista não pode avalizar, mas que, a despeito disso, a metafísica eleva a segunda potência. Do mesmo modo, demonstra-se como a fantasia forja a idéia de um eu inalterado e idêntico a si mesmo no decorrer do tempo. Em ambos os casos, a filosofia de Hume esquadrinha o mesmo fenômeno: a metafísica constrói conceitos a partir de uma base fictícia fornecida pela atividade da fantasia, na tentativa de contornar contradições surgidas do exame daquelas duas ilusões naturais e com o objetivo de assegurar racionalidade e inteligibilidade a uma experiência que é um diverso de percepções descontínuas, distintas e separadas umas das outras.

II

É pela análise da crença nos objetos externos que começa o enredo das ilusões naturais e das ficções filosóficas. A questão aqui não reside exatamente em duvidar dessas existências. Crer nos corpos é 
uma determinação natural e, nessa medida, inevitável. Nem mesmo o cético mais obstinado é capaz de levantar dúvidas que ponham xeque essa conviç̧ão. "A natureza não deixou isso à sua escolha; sem dúvida considerou o caso de importância grande demais para ser confiado aos nossos raciocínios e especulações incertas" (TNH, p. 187). ${ }^{146}$ A seção Do ceticismo quanto aos Sentidos não é uma retomada dos argumentos céticos contra a evidência sensível ou uma tentativa de negar a existência dos corpos. O viés da análise é, em certo sentido, naturalista. Pois, toma como ponto de partida o fato de que, a despeito das dificuldades que uma análise possa revelar, a crença nos corpos persiste em todos os homens. Por isso, a preocupação de Hume não está em investigar se tais objetos realmente existem, mas em compreender as causas que nos levam a crer em sua existência.

Considerada do ponto de vista da filosofia, essa crença envolve ao menos duas dificuldades. Por um lado, ela supõe a atribuição de uma existência contínua de objetos, nem sempre presentes aos sentidos. Por outro, ela envolve a conviç̧ão de tais objetos existem de forma distinta e independente da mente e da percepção. A ligação entre ambos os problemas é evidente. Como ressalta Hume no Tratado, essas questões implicam-se reciprocamente.

Essas duas questões a respeito da existência continua e distinta do corpo estão intimamente conectadas. Pois se os objetos de nossos sentidos continuam a existir mesmo quando não são percebidos, sua existência é obviamente independente e distinta da percepção, e vice-versa, se sua existência é independente e distinta da percepção, eles devem continuar a existir mesmo quando não são percebidos. ( $T N H$, p.188)

\footnotetext{
${ }^{146} \mathrm{Na}$ Investigação Hume enumera os argumentos céticos contra a evidência dos sentidos e a crença nos corpos. A este respeito, cf. Investigação, p. 151.
} 
Desdobrado nessas duas questões, o problema da existência dos objetos externos revela-se relativo à duração e à identidade que atribuímos aos corpos. Trata-se de compreender que processos nos levam a crer que o objeto de uma impressão sensível permanece existente e idêntico a si próprio, a despeito das inúmeras interrupções de sua percepção. Em outras palavras, o problema reside em explicar como somos capazes de superar a fugacidade das impressões, atribuindo-Ihes uma existência duradoura e independente da percepção.

Esse resultado não se deve à ação dos sentidos. Para além do fato de que Ihes atribuir a causalidade da crença nos objetos seria uma "contradição", a impressão sensível não é uma representação ${ }^{147}$. E, por isso mesmo, a sensação não nos remete a nada de exterior a ela. Como já vimos, os sentidos nos transmitem uma "percepção singular" que não pode dar ocasião à concepção de uma "dupla existência". Desse modo, quando a mente ultrapassa a imediatez das impressões - concebendo um objeto correspondente como sua causa, à qual elas se assemelham deve haver alguma operação da razão ou da imaginação. Ainda que a "dupla existência" e todas as complicações derivadas da tese da correspondência entre representação e objeto não estejam em causa, é impossível que os sentidos sozinhos sejam capazes de produzir a ilusão de que nossas percepções são exteriores à mente. Com efeito, essa crença demanda uma série de passos demasiado complexos para essas faculdades. Para tanto, seria preciso, em primeiro lugar, que a distinção entre nós mesmos e os objetos fosse evidente para os sentidos. Mas esse não é o único problema. Essa operação envolve a consideração de questões complexas, como a determinação da identidade pessoal, a distinção entre os diversos gêneros de impressão, a compreensão de nosso corpo como corpo próprio, a noção de distância e determinação

\footnotetext{
${ }^{147}$ Sobre essa aparente contradição, cf. TNH, p. 188.
} 
da impossibilidade de que algumas percepções possuam extensão ${ }^{148}$. Se os sentidos não nos enganam é em virtude do fato de que, em sua simplicidade, eles nos apresentam suas percepções em suas "verdadeiras cores": "os sentidos não nos dão qualquer noção de existência contínua, pois não podem operar além da extensão em que operam". (TNH, p.191) Por limitarem-se estritamente ao domínio que Ihes é próprio esses órgãos não nos apresentam suas impressões nem como representações, nem como os próprios objetos.

Curiosamente, a despeito de suas diferenças, filósofos e homens comuns concordam em diversos casos quanto à existência distinta e continua de nossas sensações. Pelos sentidos somos afetados por três espécies de impressão, aquelas referentes à figura, movimento e volume; as que transmitem sensações de cores, sabores, aromas, sons calor e frio; e as que dizem respeito às dores e prazeres resultantes da aplicação de um objeto ao nosso corpo. Tanto os filósofos quanto o vulgo atribuem existência distinta e contínua às percepções da primeira espécie, ambos concordam quanto ao fato de que aquelas da terceira espécie são descontínuas e dependentes da mente. Apenas quanto às sensações da segunda espécie é que há desacordo entre ambos, pois, enquanto o vulgo atribui existência contínua e independente ás cores, aromas e sabores, o filósofo nega-se a fazê-lo. Tanto o acordo quanto o desacordo entre esses dois gêneros de homens demonstram apenas que há um "preconceito" a favor da existência contínua e distinta de certas impressões. Pois, do ponto de vista dos sentidos, todas ela estão em pé de igualdade ${ }^{149}$.

A comparação entre a opinião do vulgo e a do filósofo não serve apenas para confirmar a tese de que os sentidos nada têm haver com a crença nos corpos; explorada sob um outro ângulo ela mostra que

\footnotetext{
148 Sobre isso cf. o argumento a partir da percepção do próprio corpo em TNH, pp. 190-191.

149 Cf. TNH, pp. 192-193.
} 
tampouco é a razão que produz essa crença. Os argumentos filosóficos são de domínio de um público limitado e a convicção na existência dos corpos é comum a todos os homens. Essa crença é esposada tanto pelo homem mais ignorante quanto pelo douto, e até uma criança demonstrar crer nesse fato.

Quaisquer que sejam os argumentos que os filósofos imaginam poder produzir para estabelecer a crença em objetos independentes do espírito, é óbvio que tais argumentos são conhecidos apenas por muito poucos e que não é por sua causa que crianças, camponeses e a maior parte da humanidade atribui objetos a algumas impressões e os recusa a outras. (TNH, p.193)

Se é assim, a crença nos objetos externos não depende de nenhum argumento filosófico. Do contrário, ela seria exclusividade do filósofo e teríamos camponeses e crianças céticas.

Decerto não é isso que ocorre. Com efeito, se o vulgo e o filósofo se confrontam, é por que, enquanto a filosofia formula argumentos para demonstrar que "tudo que aparece à mente não é senão percepção, e possui uma existência descontínua e dependente da mente", o homem comum confunde percepção e objeto, atribuindo uma existência independente e contínua àquilo que sente e que vê. Os argumentos dos filósofos visam corrigir esse equívoco. Através da razão, a filosofia estabelece a distinção entre percepção e a coisa percebida e atribui somente a esta última a existência distinta e contínua. Mas o fato é que em nenhum dos dois casos é possível realizar inferências causais para nos assegurarmos da existência dos objetos dos sentidos. Pois, se percepção e objeto são a mesma coisa, essa relação não pode ser estabelecida. E se eles são seres distintos, a causalidade também não se aplica, uma vez que a idéia dessa relação vale somente para a experiência e não temos experiência direta dos objetos supostamente representados pela percepção. Vê-se assim que a situação do filósofo é 
na realidade pior que a do vulgo. Com efeito, embora a ilusão natural já colocasse problemas e demandasse uma explicação, a cisão entre objeto percebido e percepção complica ainda mais o problema. A distinção entre os dois termos envolve o filósofo em sutilezas metafísicas e o torna presa fácil para o cético.

Aqui você se afasta de suas inclinações naturais e sentimentos mais óbvios. E ainda assim, não pode jamais satisfazer sua razão, que não pode nunca encontrar, a partir da experiência, um argumento convincente para provar que as percepções são conectadas a quaisquer objetos externos. (TNH, p. 193)

Assim, a crença nos objetos externos não pode ser atribuída nem à razão, nem aos sentidos. É a partir da concorrência de algumas qualidades das impressões sensíveis com qualidades da imaginação que surge a crença sensível.

Mas de que modo essa combinação produz tal convicção? Por um lado, somos levados a conceber algumas percepções como objetos independentes e existentes fora de nós devido à constância com que nos aparecem, sempre dispostos de maneira regular no espaço e apresentando as mesmas qualidades físicas: "Minha cama e minha mesa, meus livros e papéis, apresentam-se da mesma maneira uniforme e não mudam conforme qualquer interrupção em meu ato de vê-los ou percebê-los." ( TNH, p.194) Na ausência dessa qualidade seríamos naturalmente levados a considerar os objetos de nossas percepções como existências internas e dependentes do espírito. A manutenção da disposição espacial e das qualidades sensíveis dos objetos confere força a suposição de que eles possuem duração e independência em relação a nossas faculdades.

Contudo, essa qualidade dos objetos não é suficiente para que nós Ihes atribuamos tal status. Com efeito, a disposição espacial e as 
qualidades físicas dos objetos são passíveis de transformações no decorrer do tempo.

Essa constância não é, entretanto, tão perfeita a ponto de não admitir exceções bastante consideráveis. Freqüentemente os corpos mudam sua posição e suas qualidades e, após uma breve ausência ou interrupção, podem se tornar quase irreconhecíveis. (TNH, p. 194)

É necessário, portanto, que haja a concorrência uma outra qualidade para que a crença na existência externa seja produzida. É pela coerência nas mudanças observadas nos objetos que superamos a imediatez das impressões e atribuímos, a algumas delas, uma existência contínua e distinta. Essa coerência faz com que concedamos identidade e permanência aos objetos externos, pois ela permite que encontremos uma regularidade em meio à mudança.

Essa análise, porém, ainda não está completa. A conjunção da coerência e da constância é insuficiente para explicar tal crença. As paixões, por exemplo, são dotadas dessas qualidades, mas, mesmo assim, não são consideradas como independentes, nem contínuas. 0 exemplo das paixões deixa claro que as impressões sensíveis não são os únicos conteúdos dotados de ambas as qualidades.

Sabe-se pela experiência que nossas paixões possuem conexão e dependência mútuas umas com as outras, mas em nenhuma ocasião é necessário supor que elas existam e operavam quando não eram percebidas para que se mantenha a mesma dependência e conexão de que tivemos experiência. ( $T N H$, p.195)

Ora, por que percepções dotadas de coerência e constância, podem ser tomadas como existências internas? Qual é a causa pela qual nos recusamos a Ihes atribuir existência distinta e contínua, assim como fazemos com os objetos dos sentidos? 
A análise de uma circunstância comum do cotidiano fornece esta resposta:

Eis-me aqui, sentado em meu quarto, em frente à lareira; todos os objetos que atingem meus sentidos estão ao meu redor. Minha memória me informa da existência de muitos objetos, mas esta informação não se estende para além de suas existências passadas e nem minha memória, nem meus sentidos dão-me qualquer testemunho da continuidade de seus seres. (TNH, p.196)

Um homem irrompe no quarto portando uma carta de um amigo que se encontra em um país distante. Sei pela experiência passada que a porta só se abre caso mova-se a sua maçaneta, sei também que um homem não é capaz de flutuar no ar, sei que ele precisa usar a escada para chegar a mim. Por todas essas circunstâncias, sou levado a considerar que o portador da carta subiu a escada e moveu a maçaneta. Em outras palavras, é para manter a coerência entre a minha experiência passada e os fatos que se apresentam agora a mim que minha imaginação é levada a forjar a crença na existência independente de objetos que não são imediatamente percebidos.

Mas isto não é tudo. A carta que acabei de receber me informa que meu amigo se encontra em um lugar longínquo. Percorro então toda a distância que nos separa, considerando sempre como existentes os lugares que se situam entre ele e eu. Falando rigorosamente, fenômenos como esses (a aparição do portador e a transição de idéias que decorre das informações da carta) seriam contraditórios com nossas inferências tiradas a partir da relação de causa e efeito, se supuséssemos a aniquilação dos objetos a cada vez que deixamos de percebê-los. A observação das operações da mente acima descritas revela uma contradição entre o sistema da causalidade e o fluxo de 
percepções ${ }^{150}$. "Estou acostumado a ouvir tal som e a ver tal objeto em movimento, no mesmo momento. Eu não recebi, neste exemplo em particular, qualquer uma destas duas percepções." (TNH, 196) O sistema da causalidade nos revela uma regularidade da experiência. Mas, dado o caráter fragmentário da mesma, é preciso assegurar essa regularidade.

Mas é evidente que sempre que inferimos a existência contínua dos objetos dos sentidos, partindo de sua coerência e da freqüência de sua união, o fazemos no intuito de atribuir aos objetos uma regularidade maior que a observada em nossas meras percepções. (TNH, p. 197)

O problema é que pelo princípio da diferença e da separação sei que minhas percepções são distintas e independentes umas das outras. Se a minha percepção passa de uma à outra, deixando algumas de lado ao longo do tempo, preciso me assegurar das regularidades constatadas, sob pena de colocar todo o sistema em risco. Nenhuma delas pressupõe em si mesma a existência das outras. Por isso, é necessário que eu suponha, em primeiro lugar, a existência contínua dos corpos. E é a imaginação que se encarrega dessa tarefa. Pode-se dizer que a hipótese da existência contínua seria inadmissível, não fosse ela inteiramente necessária para desfazer a contrariedade entre a intermitência de minhas percepções e o sistema formado pela memória e pelo entendimento.

Uma coisa é mostrar a necessidade de uma crença e outra é explicar sua gênese. Hume inicia essa explicação excluindo a possibilidade de que ela seja um efeito direto do costume.

\footnotetext{
${ }^{150}$ Deleuze explica de forma clara e precisa a contradição que surgiria entre o sistema formado a partir da causalidade e as interrupções e a descontinuidade das percepções: "Assim se resolve a contradição que haveria entre a conjunção de dois objetos na experiência corrente e a aparição de um dos objetos em minha percepção sem que apareça, ao mesmo tempo, o seu par." (Empirisme et Subjectivité, p. 79)
} 
Aparentemente, a crença causal e a crença na existência distinta são da mesma ordem, ambas derivam do costume e são reguladas pela experiência passada. Mas essa identidade é apenas aparente. Diferentemente da crença causal, a crença nas existências externas deriva da influência do hábito de uma maneira bastante "indireta" e "oblíqua". Todo hábito deriva da observação de sucessões regulares de percepções e, por isso, não pode haver nenhum hábito que extrapole a regularidade percebida.

Nenhum grau de regularidade em nossas percepções poderia ser o fundamento para inferirmos um grau de regularidade ainda maior em alguns objetos que não são percebidos. Pois isto supõe uma contradição, a saber: um hábito adquirido por meio de algo que nunca esteve presente à mente. (TNH, p. 197)

Como não posso inferir pelo costume aquilo que não me é dado empiricamente, a ação do hábito e a observação da experiência passada são insuficientes para explicar o processo pelo qual somos levados a crer nos objetos dos sentidos. Com efeito, essa convicção preserva o sistema formado pelo hábito e possui, portanto, alguma relação com esse princípio. Mas é impossível que ela seja gerada apenas por ele $\mathrm{e}^{151}$.

É uma inclinação da imaginação que responde pelo maior quinhão da produção dessa crença. Quando discute as fundações das matemáticas, Hume observa que essa faculdade tende a prolongar uma cadeia de raciocínio, mesmo que Ihe faltem elementos para tanto ${ }^{152}$. Essa tendência é uma característica da imaginação, uma regularidade em seu modo de operar a transição das idéias, um elemento tão constante que Hume chegará a referir-se a ele como um princípio. "O mesmo princípio nos leva a adotar sem mais a opinião da existência dos corpos." (TNH, p. 198) Algumas qualidades das percepções concorrem

\footnotetext{
${ }^{151}$ Cf. $T N H$, p. 198.

${ }^{152} \mathrm{Cf} . T N H, \mathrm{I}, 4,1$.
} 
para que essa operação seja levada a termo. Os objetos exibem uma coerência e uma regularidade que afetam a imaginação. Diante delas a essa faculdade forja a crença na existência dos corpos para tornar tal regularidade ainda mais completa. Esse movimento é reforçado e essa crença vivificada, na medida em que, além da coerência, minhas percepções são também dotadas de constância.

Como ocorria com a coerência, a constância desempenha aqui um papel central. Sua análise, no entanto, revela um novo grau de complexidade da questão, pois traz à tona a relação entre o problema da identidade e a crença na existência do mundo externo.

Quando estamos habituados a observar uma constância em certas impressões, quando constatamos, por exemplo, que a percepção do sol ou do oceano retorna a nós, após uma ausência ou supressão, com partes e em ordem semelhante a de sua primeira aparição, não nos prontificamos a considerá-los como diferentes (como realmente são), mas, ao contrário, a considerá-los como os mesmos individualmente, devido à sua semelhança. ( $T N H$, p. 199)

Minhas percepções do oceano são descontínuas e fragmentadas. Essa descontinuidade contraria sua identidade e põe em xeque a sua permanência na existência, quando elas não estão diante de mim. De fato, conforme o texto citado, trata-se de percepções distintas. O sol que vejo hoje não é a mesma percepção que verei amanhã. Não obstante esse fato, a constância com a qual essa impressão me aparece e a semelhança entre ela e suas congêneres leva-me a concebê-la como sendo uma e a mesma coisa. Ao atribuir-lhe existência contínua, atribuo-Ihe, igualmente, identidade numérica.

Como mostram as quatro etapas implicadas na análise desse fenômeno, no quadro conceitual estabelecido pela distinção absoluta entre minhas percepções essa operação da imaginação está longe de ser simples. Em primeiro, lugar, é preciso esmiuçar melhor a noção de 
identidade, explicando em que consiste o principium individuationis. Em segundo, determinar a razão devido à qual a semelhança entre aquelas percepções leva a imaginação a Ihes atribuir identidade. Em terceiro, explicar a tendência de unir percepções descontínuas em uma existência continua. $\mathrm{E}$, por último, é necessário identificar de onde derivam a força e a vivacidade da crença nessa existência.

Onde está exatamente o problema posto pela identidade? Sabemos que todas as percepções são distintas. Essa diferença, como já vimos, é conseqüência da aplicação do princípio da diferença e da separação, que está raiz do atomismo humiano. A distinção entre todas as nossas impressões e idéias é que o torna a categoria da identidade algo especialmente difícil na filosofia de Hume. A "visão de um objeto é insuficiente para nos transmitir a idéia de identidade" ( $T N H$, p. 200) Estando diante de um objeto único não tenho a idéia de identidade, mas de unidade ${ }^{153}$. E a contemplação de diversos objetos, por outro lado, nos fornece apenas a idéia de multiplicidade. Tanto uma quanto a outra são características incompatíveis com a noção de identidade e, por isso, essa última deve ser algo distinto delas ${ }^{154}$.

A dificuldade reside no fato de que a identidade demanda uma síntese complexa que envolve não apenas a presença de uma impressão, mas a ilusão de sua duração no tempo. A contemplação de uma única percepção que não sofre alterações não me forneceria a noção de tempo. Em vez disso, essa percepção fixa e estanque, para usarmos os termos de Malherbe, "abole o tempo ${ }^{155 " .}$ Com efeito, o tempo implica uma sucessão ou fluxo de percepções. Ele é um movimento, em vez de uma imobilidade e permanência. Mas, para que a

\footnotetext{
${ }^{153}$ Cf. TNH, p.200: "Um objeto isolado transmite a idéia de unidade, e não de identidade."

${ }^{154}$ Essa ordem de exposição, que parte da unidade e da multiplicidade explica-se, como nota Wayne Waxman, do fato de que, quando Hume se refere à identidade, ele se refere a "identidade numérica", a qual difere tanto da multiplicidade, quanto da unidade. Sobre isto cf. Hume's theory of consciousness, p. 203.

155 Cf. Malherbe, La Philosophie Empiriste de Hume, p. 153.
} 
identidade possa ser forjada é preciso que tenhamos uma impressão que permanece imutável, embora participe das "mudanças dos objetos coexistentes".

É através de uma ficção da imaginação que essa primeira etapa da formulação da identidade é vencida. Há dois modos de considerar a sucessão temporal. A imaginação pode, primeiramente, tomar dois pontos do tempo simultaneamente, e conceber o mesmo objeto em ambos. Essa operação nos obriga a multiplicar tal objeto e nos fornece a idéia de número. Por outro lado, é possível à imaginação acompanhar "a sucessão do tempo por uma sucessão semelhante de idéias", concebendo um objeto que permanece igual a si mesmo do primeiro ao último instante considerado. É dessa operação fictícia da imaginação que surge a primeira idéia de identidade. O objeto dotado dessa característica é justamente aquele que permanecer invariável, dotado de unidade numérica e cuja existência não sofre interrupções ao longo da sucessão temporal ${ }^{156}$. Ele participa das mudanças do tempo, pois, está inscrito na série temporal, mas não sofre alterações enquanto ela se desdobra.

Trata-se evidentemente de uma ficção, pois, tais características não são observadas na sucessão de nossas impressões. O que vemos, em vez disso, é um fluxo e nada nos garante estejamos diante da mesma impressão em dois instantes distintos. De todo modo, a partir dessa fabulação da fantasia é que podemos observar que:

O princípio de individuação não é senão a invariabilidade e continuidade de um objeto ao longo de uma suposta variação do tempo pela qual a mente pode acompanhá-lo nos diferentes períodos de sua existência sem nenhuma quebra

\footnotetext{
${ }^{156}$ Como nota Malherbe, essa ficção é importante para a própria elaboração do tempo. Sem ela a sucessão ficaria descosida e perderíamos a idéia de uma continuidade do tempo. Cf. La Philosophie Empiriste de Hume, pp. 153-154.
} 
de perspectiva e sem ser obrigada a formar uma idéia de multiplicidade ou de número. (TNH, p. 201)

A atribuição de identidade numérica a um objeto envolve, assim, a crença na sua duração - o que implica a convicção em sua invariabilidade e continuidade no transcorrer do tempo. A gênese das fiç̧ões deve, portanto, recuar até aqui. Não é difícil ver quais obstáculos presentes nesse caso. Quando cremos que um objeto seja dotado dessas qualidades, contrariamos dois fatos fundamentais: 1) nossas percepções são todas distintas umas das outras, e nada nos assegura de que estamos diante de uma mesma impressão ao longo do tempo, uma vez que essas são existências particulares e efêmeras; 2) a aparição de nossas percepções não é ininterrupta, pelo contrário ela é fragmentada. É preciso, então, mostrar de que forma a imaginação é capaz superar, de um lado, a diferença entre nossas impressões e, de outro, a fragmentação da percepção. Se levássemos o atomismo em consideração em nossa vida comum, seríamos obrigados a considerar que os objetos que nos aparecem após alguma interrupção na percepção, teriam sido aniquilados momentaneamente e criados novamente. Deveríamos considerar que estamos diante de um novo objeto, a despeito da similaridade entre as qualidades sensíveis e a disposição do primeiro e do segundo no espaço.

Essa manobra pela qual a mente dribla, por assim dizer, o atomismo, só é possível devido a uma outra tendência da imaginação e a uma relação natural.

Nada é mais capaz de nos fazer confundir uma idéia com outra que uma relação entre elas que as associa na imaginação fazendo-a passar com facilidade de uma a outra. De todas as relações, a semelhança é a mais eficaz sob esse aspecto, pois não somente causa uma associação de idéias como também de 
disposições, e nos faz conceber uma idéia através de um ato ou operação da mente similar àquele pelo qual concebemos outra. ( $T N H$, p.202)

A semelhança produz uma tendência à confusão, não só de objetos, como de as disposições da mente relativas a atos e operações mentais similares ${ }^{157}$. Idéias semelhantes são passíveis de serem confundidas, pois, põem a mente em disposições semelhantes e fazem com que a transição de uma a outra seja quase que imperceptível. Disposições demasiadamente semelhantes nos levam, portanto, a confundir os objetos que as causam e a concebê-los como idênticos. "A mente passa prontamente de uma à outra e não percebe a mudança, a não ser por uma rigorosa atenção, da qual, em geral, ela é inteiramente incapaz." ( $T N H$, p.203) É devido a essa facilidade de transição, a qual torna as diferenças quase imperceptíveis que a constância nos afeta, fazendo-nos deixar de lado a descontinuidade da percepção e levando-nos a fabricar a ilusão da identidade dos objetos sensíveis.

São dois os casos nos quais essa mecânica pode ser observada. Em primeiro lugar, a contemplação de idéias aparentemente idênticas preserva a disposição inicial da imaginação. O mesmo efeito ocorre quando temos idéias relacionadas umas às outras. Nesse último caso, a passagem entre os correlatos é tão fácil e suave que não produz alterações na mente. E o "pensamento desliza ao longo da sucessão, com a mesma facilidade com que considera um objeto único, e confunde a sucessão com a identidade." (TNH, p. 204) No fundo da ilusão que leva a mente a atribuir uma identidade aos objetos externos está uma relação de semelhança que opera em dois níveis. Num deles, o mais

\footnotetext{
${ }^{157}$ Vale notar que esse mecanismo que nos leva a associar disposições e confundir atos mentais já era revelado no $T N H$, quando Hume afirma: "Das três relações supracitadas, a de semelhança é a fonte mais fértil de erro. $\mathrm{E}$, de fato, há poucos erros do raciocínio que não são devidos, em grande medida, dessa origem. Idéias semelhantes são intimamente relacionadas, e as ações da mente que empregamos ao considerá-las são tão similares que não estamos aptos a distinguilas." (TNH, p. 61)
} 
evidente, trata-se da similaridade entre as próprias percepções. Noutro, menos óbvio, trata-se de uma semelhança entre as disposições da mente. É principalmente essa última similaridade, a qual é em certa medida dependente da primeira, que favorece a fiç̧ão. Pois, com ela a imaginação dá livre curso a sua tendência natural, que consiste em associar idéias. Aqui, a semelhança entre os atos mentais facilita a transição entre minhas percepções e faz com que eu ajuste aquela semilaridade entre os objetos, a despeito da descontinuidade de suas aparições. Estando diante de objetos similares, com a imaginação em situações semelhantes, sou levado a transformar aquela primeira semelhança em identidade.

Essas circunstâncias explicam o efeito da constância e da coerência sobre a mente.

Descobrimos pela experiência uma tal constância em quase todas as impressões dos sentidos, que sua interrupção não produz nelas nenhuma alteração, nem as impede de retornar iguais, em aparência e situação, ao que eram em sua primeira existência. ( $T N H$, p. 204)

Ainda que a percepção dos objetos seja intermitente, eles aparecem dispostos de maneira semelhante no espaço e apresentam qualidades sensíveis similares com enorme freqüência. Por isso, a mente passa sem esforço de um a outro, quando estão relacionados.

Uma transição ou passagem fácil da imaginação pelas idéias dessas percepções interrompidas e diferentes é praticamente a mesma disposição da mente pela qual consideramos uma percepção ininterrupta e constante. É, portanto, muito natural que as confundamos umas com as outras. ( $T N H$, p. 204)

E quando a constância se quebra, na imensa maioria dos casos constatamos que as mudanças obedecem a certas regularidades, que elas são coerentes entre si, o que leva a mente a manter essa ilusão. 
Assim, efeito da constância e da coerência, e a dupla semelhança (entre objetos, de um lado, e disposições da mente, de outro) mostram como se produz a ficção da identidade. O problema é que essa mecânica não explica como a imaginação supera a contrariedade entre a interrupção de nossas percepções e a atribuição de identidade ao objeto.

Mais uma vez é preciso voltar os olhos para as propensões da imaginação e para o sentimento, de modo a compreender como se supera essa contradição. Em primeiro lugar, é necessário considerar uma espécie de ajuste que se realiza para suprimir o desprazer gerado pela contrariedade entre a tese da identidade e a experiência da interrupção das percepções. É fato, diz Hume, que "qualquer contradição, seja ela dos sentimentos ou paixões, produz um sensível desconforto, quer ela venha de fora ou de dentro, da oposição de objetos externos, ou do combate de princípios internos." (TNH, p. 205) Por outro lado, tudo aquilo que se "harmoniza com as propensões naturais e favorece externamente sua satisfação, ou concorre internamente com seus movimentos, produz com certeza um prazer sensível." (TNH, p. 205) Evidentemente, o desconforto em questão vem do fato de que a semelhança entre os objetos e a transição fácil nos fazem atribuir-Ihes identidade, ao mesmo tempo em que a interrupção de suas aparições levanta a questão de sua aniquilação. Esse desconforto será eliminado, nos termos de Hume, mediante o "sacrifício", de um dos lados da questão.

Essa contradição é inevitável e gera desprazer, pois, temos a experiência da interrupção da percepção e, não obstante isso, devido à semelhança somos levados à ficção identidade ${ }^{158}$. A contradição é também flagrante, pois, admitindo-se que a mente não seja senão um

\footnotetext{
${ }^{158}$ Convém notar com Hume que esse problema toca tanto o filósofo, quanto o senso comum. Afinal, embora a filosofia busque uma solução ao diferenciar o objeto e a percepção, na maior parte do tempo ele pensa como o vulgo e não distingue esses dois termos. Sobre isso cf. $T N H$, pp. 206-207.
} 
feixe de percepções distintas unidas por relações, não é absurdo supor que uma percepção particular qualquer seja aniquilada, que deixa de existir quando deixo de percebê-la. De modo que a ausência da percepção pode perfeitamente significar sua inexistência, e o retorno de um conteúdo a ela similar em todas as suas características não é, a rigor, uma garantia de que estou diante do mesmo objeto que eu observava anteriormente. Mas justamente essa similitude faz a imaginação pender para o lado da identidade e "sacrificar" a constatação da interrupção e da heterogeneidade da percepção. Impulsionada pela semelhança e tendendo sempre a eliminar um "desconforto" a imaginação se exerce como fantasia para conciliar a identidade do objeto ausente com as interrupções de sua aparição. E o que essa faculdade fantasia é justamente existência contínua e ininterrupta desse objeto. A tese da existência independente e distinta surge depois, justamente em decorrência dessa ilusão primeira.

Mas uma coisa é uma idéia fictícia e outra bem diferente é uma crença. A questão, portanto, é como essa fiç̧ão torna-se conviç̧ão? Decerto, a facilidade de transição de uma idéia à outra, causada pela relação de semelhança, contribui para esta vivificação. No entanto, uma idéia é tanto mais viva quanto mais próxima estiver de uma impressão. É nessa medida que as impressões da memória contribuem para a produção da crença nos corpos.

\footnotetext{
Temos aqui uma propensão a simular (feign) a existência contínua de todos os objetos sensíveis, propensão essa que surge das impressões vivas da memória e concedem uma vivacidade àquela ficção e que nos levam em suma, a crer na existência contínua do corpo. ( $T N H$, p. 209)
}

Uma crença pode ser produzida e reforçada, por diversas causas, mas a causa mais forte da crença será sempre uma impressão a ela relacionada. As impressões da memória são, portanto, causas da 
vivificação da ficção da existência contínua e distinta dos corpos e pela crença que ela suscita ${ }^{159}$. É devido à influência dessas impressões que a idéia de existência dos objetos externos ganha o estatuto de crença.

Não há dúvidas quanto ao alvo de Hume nessa análise. Resultante de tendências da imaginação e da relação natural de semelhança a crença no mundo externo é uma ilusão natural. Enquanto tal ela permite, primeiramente, compreender a conviç̧ão vulgar na existência do mundo exterior. Em segundo lugar, ela dá a chave para uma crítica da filosofia, pois permite, simultaneamente, localizar as raízes da tese da dupla existência e demonstrar sua ilegitimidade. Ora, de acordo com a opinião do homem comum não há diferença entre percepção e objeto. Pelas causas explicadas acima, ele é levado a desconsiderar que a interrupção das percepções seja algo real. Para ele, a aniquilação do objeto, quando esse não é mais percebido, é mera aparência. E, embora esse sistema encerre uma contradição mais que evidente, o vulgo persistirá com teimosia em sua crença ${ }^{160}$.

Seu erro, dirá o filósofo, está no fato de não distinguir entre percepção e objeto. E sua correção vem logo a seguir, com a formulação da noção de dupla existência. Com essa tese a filosofia pensa poder conciliar a fugacidade das percepções, constatada pela razão e pela reflexão, com a existência contínua dos objetos exigida pela imaginação. Assim, têm inicio a elaboração das diversas modalidades da noção de substância, as quais apenas refletem a posição incômoda na qual a filosofia acaba por se colocar. Afinal se o sistema do vulgo não passa pelo crivo da reflexão, o sistema filosófico "é passível das mesmas dificuldades [que o sistema popular] e é, ademais, sobrecarregado com

\footnotetext{
${ }^{159}$ Cf. TNH, p. 209.

${ }^{160} \mathrm{Cf}$. TNH, p. 214: "Mas, como um mínimo de reflexão destrói a conclusão de que nossas percepções tem existência contínua ao mostrar que elas têm existência dependente, é natural esperar que rejeitássemos por completo a opinião de que há na natureza algo como uma existência contínua que se preserva mesmo quando deixa de ser aparente aos sentidos."
} 
o absurdo de, ao mesmo tempo, negar e corroborar a suposição vulgar." (TNH, pp.217-214)

Não por acaso as duas seções que se seguem ao debate acerca da existência dos corpos dedicam-se ao comentário das várias soluções dadas ao problema dos objetos externos. Desde as tentativas da filosofia antiga para solucionar os problemas referentes à existência contínua, até a distinção moderna entre qualidades primárias e secundárias, a filosofia nada fez além de explicitar o apego que temos a crença no mundo externo.

Como o sistema filosófico, segundo nos mostra a experiência, se apodera de muitas mentes, em particular daqueles que refletem, por pouco que seja, sobre esse assunto, ele deve derivar toda sua autoridade do sistema vulgar - uma vez que originalmente não possui autoridade própria. ( $T N H$, p. 213)

As idéias de substância, formas substanciais, qualidades ocultas e acidentes foram ensaios malogrados dessa conciliação que a filosofia pretende realizar ${ }^{161}$. Como elas, as soluções propostas pela filosofia moderna, baseadas na distinção entre qualidades primárias e secundárias, não passam de ficções que, ao distanciarem-se da crença do senso comum, perdem seu vigor. Mas, não obstante esse fato, a filosofia demonstra quão enraizada em nossa natureza é a crença no mundo externo. Por isso é que

muitas descobertas úteis podem ser feitas com base numa crítica das ficções da filosofia antiga referentes a substâncias, formas substanciais, acidentes e qualidades ocultas, que por mais irracionais e caprichosas que sejam, possuem uma íntima conexão com os princípios da natureza humana. (TNH, p. 219)

\footnotetext{
${ }^{161} \mathrm{Em}$ carta a Lorde Kames fica clara a opinião pouco abonadora de Hume a respeito da noção de substância: "Quanto à idéia de substância, eu afirmo que ela não tem acesso à mente por quaisquer de nossos sentidos ou sentimentos (feelings); essa idéia me parece tão somente um foco imaginário para o qual convergem as diferentes qualidades variáveis encontradas em cada parcela de matéria." Cf. Letters of David Hume, carta 52, p.94.
} 
Numa análise empirista como a de Hume, todas essas tentativas esbarram em obstáculos intransponíveis e, sem a crença natural a seu favor, vão sendo descartadas, uma a uma ${ }^{162}$. E, se é possível tirar daí algum resultado concreto ele é o seguinte: a reflexão filosófica se distancia da atitude natural e se envereda em questões insolúveis abrindo caminho para o pirronismo. A verdadeira filosofia, segundo Hume, deve reconhecer essa naturalidade da crença nos objetos externos e se tender, ainda que de modo crítico, da opinião do vulgo. Há uma espécie de gradação que parte da atitude natural, passa pela falsa filosofia e retorna à opinião do vulgo:

Ao considerarmos essa questão, observamos uma gradação de três opiniões que surgem uma após a outra, conforme a pessoa que as forma adquire mais razão e instrução. Ao examiná-las, veremos que a verdadeira filosofia se aproxima mais dos sentimentos do vulgo que daqueles da erudição equivocada.

$(T N H$, p. 222)

A verdadeira filosofia se aproxima dos sentimentos do vulgo. Mas é preciso caracterizar com precisão essa afirmação. Afinal, não se trata simplesmente de aderir ao senso comum.Admitir que a crença nos objetos externos é irresistível não equivale a conceder-lhe estatuto de verdade. Se assim fosse, não haveria diferenças substanciais entre a filosofia de Hume e a filosofia do senso comum ${ }^{163}$.

Não se encontrará na filosofia humiana essa garantia sobrenatural. Em vez disso, a análise empirista e o nominalismo esposado pelo autor

\footnotetext{
162 Sobre isto cf. TNH, pp. 3-4.

163"Os filósofos do senso comum insistem que aquilo que cremos naturalmente verdadeiro deve ser aceito sem mais enquanto tal, pois estão convencidos de que nossas faculdades nos são dadas por Deus como parte do desígnio de uma natureza providencial, e que portanto são confiáveis. Ele supõem que nossas crenças naturais são garantidas por uma instância sobrenatural." (Norton, David Hume common-sense moralist, sceptical metaphysician, p. 202). O autor mostra ainda, contra Kemp-Smith, que não há acordo entre a filosofia humiana e seus adversários da escola do senso comum. Cf. p. 195.
} 
levará à conclusão de que uma crença pode persuadir, sem necessariamente ser provada como verdadeira. Com efeito, ainda que Hume reconheça que estamos diante de uma convicção inevitável, a análise do Tratado mostra que uma filosofia conseqüente se curva a essa convicção, mas se mantém consciente de que não haveria como assegurar sua realidade sem violar o método e os princípios empiristas que conduziram todo seu exame. A análise da crença nos objetos externos não é uma justificação dessa ficção. Trata-se somente de determinar-Ihe as causas e evidenciar seu caráter natural.

\section{III}

O discurso metafísico não tem mais sorte no caso da identidade pessoal que no caso dos objetos externos. As análises da crença nos corpos e da crença no self guardam diversas semelhanças entre si. Como no caso dos corpos, a suposição de um eu simples, dotado de perfeita identidade ao longo do tempo e de todas as transformações que fluxo temporal, implica uma contradição em relação ao princípio da diferença e separação. Como no caso da crença no mundo exterior, a discussão acerca do self envolve, num primeiro momento, a exposição dessa contradição e, num segundo, a explicação de sua origem a partir princípios da natureza humana e das operações e afecções da imaginação. Assim, como no exame da crença nos corpos, o exame do self a filosofia humiana não põe em xeque pura e simplesmente uma concepção genérica de sujeito, mas visa um alvo preciso.

Dando continuidade ao movimento iniciado na seção "Do Ceticismo quanto aos Sentidos", trata-se de mostrar a gênese de um conceito fundamental da metafísica, expondo seu fundamento numa ilusão natural. Desse modo, a análise humiana tem, por assim dizer, endereço certo: "Há filósofos que imaginam estarmos, em todos os momentos, intimamente conscientes daquilo que chamamos de nosso 
EU; que sentimos sua existência e sua continuidade na existência; e que estamos certos de sua perfeita identidade e simplicidade, com uma evidência que ultrapassa a de uma demonstração." (TNH, p. 251) Nesta referência que pode se aplicar tanto a empiristas como Locke, quanto a racionalistas, como Descartes, Hume aponta suas armas para uma noção que, embora careça de caução experimental é tida como evidente em boa parte da filosofia moderna ${ }^{164}$.

A mais forte sensação, a mais violenta paixão, dizem eles, em vez de nos distraírem dessa visão, apenas fixam-na ainda mais intensamente e nos fazem considerar a influência que exercem sobre o eu, seja pela dor ou pelo prazer que produzem. ( $T N H$, p. 251)

Concebido como unidade subjacente a todos os atos da mente, paixões e percepções, em geral, o eu é, segundo esses filósofos, dotado duas características essenciais: a perfeita simplicidade e a perfeita identidade. Centro de referência de todos os atos do espírito, essa noção explicaria por que, embora um homem passe por inúmeras transformações desde seu nascimento até sua morte, nós o consideramos como sendo sempre, em todos os momentos, a mesma pessoa.

É justamente a evidência dessa noção que a análise humiana vai colocar em questão logo de início. Não por acaso, o exame tem seu ponto de partida na aplicação do princípio do empirismo à idéia do eu. Ora, "deve haver alguma impressão", diz Hume, "que deve dar origem a uma idéia real." ( $T N H$, p.251) Para verificarmos se uma idéia é clara e dotada de sentido basta que busquemos a impressão que deveria originá-la. Desse modo, para que a concepção de um sujeito dotado de simplicidade e identidade perfeitas tivesse sentido e realidade seria

\footnotetext{
${ }^{164}$ Parece-nos correto dizer que Berkeley constaria entre os alvos de Hume, pois a definição berkeleyana de idéia como esse percipi pressupõe um substrato que é o espírito que a percebe. Sobre isto cf. Waxman, Hume's Theory of Consciousness, pp. 215-216.
} 
necessário remetê-la a uma impressão que continuasse invariavelmente a mesma ao longo de qualquer intervalo de tempo. Todavia, Hume não se cansa de insistir que "não há qualquer impressão constante e invariável. Dor e prazer, pesar e alegria, paixões e sensações sucedemse umas às outras, e nunca existem todas ao mesmo tempo." (TNH, p. 259) A mente, como já se observava ao tematizar as existências externas, nada mais é que um feixe de percepções em contínua sucessão. De maneira que tudo que se pode observar do sujeito, mediante uma "reflexão séria e sem preconceitos", é que o eu é um fluxo em constante movimento. No registro do puro fenomenismo de Hume, quando reflito sobre meu eu tudo que vejo são percepções particulares, distintas umas das outras, e nada mais.

Esse fenomenismo, aliado ao princípio da diferença e da separação, tem conseqüências devastadores para o eu metafísico. Afinal, se princípio nominalista da diferença e da separação vale irrestritamente, nada nesse fluxo legitima a tese existência de um sujeito subjacente às percepções.

Quando falamos do eu ou substância devemos ter alguma idéia anexada a esses termos ou eles serão completamente ininteligíveis. Toda idéia é derivada de impressões precedentes, e, como não temos uma impressão do eu ou substância como algo simples e individual, não temos uma idéia deles nesse sentido. Tudo o que é distinguível é distinto, e tudo o que é distinto é separado pelo pensamento ou imaginação. Todas as percepções são distintas. Elas são, portanto, distinguíveis e separáveis, e podem ser concebidas como existentes separadamente e existir separadamente sem que haja nisso qualquer contradição ou absurdo. (TNH, apêndice, p. 634)

Com efeito, se todas as idéias e impressões que se sucedem na mente são diferentes e separáveis umas das outras, todas são capazes de existir separadamente sem que seja necessário supor um substrato que 
as sustente em sua existência. "De que maneira, portanto, pertenceriam ao eu e como estariam conectadas a ele?" (TNH, p. 252) A mente não é um centro de referência imutável ao qual as percepções inerem e no qual elas se sucedem. Os próprios termos empregados por Hume para descrevê-la mostram que a mente é seus pensamentos, paixões e sensações, sem nenhuma remissão a um substrato. Trata-se tão somente de uma "coleção ou feixe de diferentes percepções", cujas marcas são, ao contrário do que pretendem os filósofos, a sucessão, o "fluxo" e o "movimento perpétuos". Como escreve Hume no Tratado:

Eu nunca apreendo a mim mesmo, em momento algum, sem uma percepção. Quando minhas percepções são suprimidas por algum tempo, como ocorre no sono profundo, nesse período de tempo eu me torno insensível a mim mesmo; e pode-se dizer, a bem da verdade, que eu não mais existo. ( $T N H$, p. 252)

Não é preciso muito esforço para ver que nada resta aqui daquela noção de sujeito dos filósofos. Pois, caracterizado pelo fluxo perpétuo, o self é uma sucessão passível de descontinuidade e interrupção; é antes uma maneira de falar, que nada tem a ver com a idéia subjetividade da filosofia moderna. Contrariando a observação, a tradição moderna atribuía ao sujeito uma identidade imutável ao longo do tempo e uma simplicidade a cada instante contraditórias ao movimento do feixe de percepções. A crer no breve resumo da filosofia moderna oferecido por Merleau-Ponty em "Em toda Parte e em Parte alguma", a conclusão desse primeiro momento da análise é uma espécie de pesadelo para a filosofia do sujeito. Com efeito, se Merleau-Ponty está certo e "Sejam quais forem as suas discordâncias, os modernos têm em comum a idéia de que o ser da alma ou o ser-sujeito não é um ser menor, que talvez seja a forma absoluta do ser ${ }^{165 ",}$, Hume é, para dizer o mínimo, uma

\footnotetext{
${ }^{165}$ Cf. Merleau-Ponty, Em toda Parte e em Parte alguma, in: Signos, p. 168.
} 
nota dissonante dessa tradição. Pois, ao diluir a identidade pessoal na mera sucessão de percepções, essa forma do ser se dissipa no movimento constante, perdendo sua fixidez, sua imutabilidade e sua simplicidade. E, doravante, a alma, a substância, ou o eu passarão a serem explicados como ilusões forjadas a partir da necessidade de conciliar a variação e o movimento das percepções com a tendência da imaginação a atribuir-Ihes uma fixidez e uma continuidade que, de fato, não possuem ${ }^{166}$.

Nessa medida a ilusão dos sentidos e a do eu formam um todo. "Para justificarmos a nós mesmos esse absurdo, nós freqüentemente simulamos (feign) um princípio novo e ininteligível, que conecta os objetos e impede sua interrupção ou variação." (TNH, p. 254) A fluidez do pensamento e da percepção em geral, o movimento e, numa palavra, a variação constante da imaginação contrariam a propensão a atribuirmos identidade, propensão essa que, como vimos é da própria dessa faculdade. Por essa razão é que somos levados a forjar a idéia de identidade pessoal. Se a ilusão das existências externas se colocava para eliminar a interrupção da percepção, é a agora a variação que está em jogo. A análise da idéia do eu traz a discussão acerca da identidade de volta à baila.

Essa análise, porém, não consiste na mera retomada das conclusões extraídas do exame da crença dos corpos. Embora em sua raiz as gêneses desses dois, por assim dizer, gêneros de crenças sejam explicadas pela mesma mecânica geral, a fabulação da identidade pessoal implica alguns passos que não estão presentes no caso das

\footnotetext{
${ }^{166}$ Decerto o cartesianismo é aqui um dos alvos preferenciais da crítica humiana. O Resumo do Tratado é explícito a esse respeito: "Descartes sustentava que o pensamento é a essência da mente, não este ou aquele pensamento, mas o pensamento em geral. Isso é absolutamente ininteligível, já que tudo que existe é particular, e, portanto, são nossas diversas percepções particulares que compõem a mente. Eu digo compõem-na, e não pertencem a ela: a mente não é uma substância à qual as percepções são inerentes. Essa noção é tão ininteligível quanto a noção cartesiana segundo a qual o pensamento ou percepção em geral é a essência da mente." (Resumo do Tratado, p. 658)
} 
existências externas. Por isso, o comentário acerca dessa ilusão segue uma progressão diferente da discussão acerca da crença no mundo exterior. Pois, no caso presente, não basta explicar como atribuímos identidade ao um objeto externo considerado em termos gerais. Com efeito, nesse último, tratava-se de explicar a atribuição de identidade e, portanto, da continuidade, a um conjunto de percepções que me aparecia ligado pela relação causal, dotado de certa coerência, constância e regularidade, embora percebido de forma interrompida. A ilusão natural se impunha a partir da necessidade de assegurar o sistema da causalidade diante do fato de que minha apreensão da experiência é fragmentada, interrompida e composta por percepções distintas umas das outras.

A identidade do eu é posta em termos de identidade pessoal e, por isso, exige uma aproximação diferente e envolve outras etapas. Com efeito, nesse caso, há uma dificuldade adicional, uma vez que é preciso demonstrar que, embora ao longo de sua existência uma pessoa possa passar por transformações capazes de torná-lo quase que irreconhecível, somos levados a crer que seu eu permanece sempre o mesmo, que se trata da mesma pessoa ${ }^{167}$. Assim, ainda que na base a atribuição de identidade aos objetos e ao sujeito deva-se a um mesmo mecanismo, o problema é, no último caso, mais complexo. Nos seres vivos e, sobretudo nos homens, a mudança é mais evidente, sendo quase que inerente à sua condição de viventes. E se essa variação é observável nas qualidades sensíveis dos organismos, ela é tanto maior quando trata-se de descrever o mundo mental.

Por essa razão, Hume tem de explorar outros aspectos da questão e se vê obrigado a realizar uma aproximação gradual, passando pela projeção da identidade nos objetos externos, estendendo-se e

\footnotetext{
${ }^{167}$ Sobre isto cf. por exemplo, TNH, p. 257: "Uma criança se torna um homem, engorda e emagrece sem qualquer mudança de identidade."
} 
detalhando a produção dessa qualidade nos objetos da arte humana, elaborando uma explicação para o problema no que tange aos organismos, para só então chegar à noção de sujeito em suas diversas formulações ${ }^{168}$. Essas transições difíceis exploram aspectos complexos da atribuição de identidade numérica a uma coisa e dão o ritmo de uma análise que Hume qualificou, com muita propriedade, como um "labirinto".

Assim, após retomar a atribuição da identidade em geral, Hume realiza a análise de uma "massa de matéria" constituída por parte contíguas no espaço e à qual atribuímos identidade. Evidentemente, se essas partes sofrerem alguma adição ou subtração, o todo também será alterado e sua identidade perdida. Todavia, o que se constata é que, a depender do grau dessas mudanças, somos levados, contra toda evidência da razão, a manter intacta a identidade do objeto. À semelhança do que ocorria no caso da crença nos corpos, esse resultado é tributário de ação das relações naturais que produzem uma transição de tão suave e fácil da primeira à segunda percepção, nos dão a ilusão de que contemplamos continuamente um mesmo objeto ${ }^{169}$. Assim, a despeito da alteração sofrida pelo objeto, mantemos sua identidade através de uma ilusão. Quando as alterações são insuficientes para produzir interrupções e diferenças consideráveis na atividade da imaginação, essa faculdade não percebe distinção entre os atos pelos quais percebe dois objetos que são, na realidade, distintos. Por isso, tais mudanças terão de ser consideradas em proporção à grandeza do todo: "a adição ou subtração de uma montanha não é suficiente para produzir

\footnotetext{
${ }^{168} \mathrm{~A}$ análise da contigüidade oferece uma nova visada da identidade dos objetos materiais, abrindo caminho para uma investigação que culmina no exame dos organismos. É importante notar ainda que quando nos referimos a objetos materiais não fazemos senão variar a expressão do próprio Hume nesse momento da argumentação, onde ele se refere a uma "massa de matéria". Evidentemente, o uso desses termos deve ser compreendido nos limites implicados pelos resultados da análise da crença nos corpos.

${ }_{169}$ Cf. $T N H$, pp. 255-256.
} 
diversidade num planeta; mas a alteração de algumas polegadas poderia destruir a identidade de alguns corpos." ( $T N H$, p. 256)

De modo semelhante, alterações graduais, quando acompanhadas continuamente, têm pouco efeito sobre a imaginação e mantém suas disposições quase inalteradas, preservando a identidade e a existência contínua da coisa percebida. E, em alguns casos, quando as diferenças oriundas de diversas transformações tornam-se demasiado evidentes para serem desconsideradas a percepção de uma finalidade inscrita nessas transformações vem ao resgate de sua identidade. "O fim comum para o qual as partes conspiram é o mesmo em todas as suas variações e permite que a imaginação faça a transição de uma situação do corpo a outra." (TNH, p. 257) Esse caso se aplica evidentemente a certo gênero de objeto que não é dos mais comuns. É nas produções da arte que podemos encontrar essa forma de organização que evidencia uma finalidade. Nesses objetos, cuja organização finalista conhecemos com certeza, a própria finalidade serve de fundamento para a ilusão da identidade. Assim, quando acompanhamos a reforma de um navio ou qualquer outro resultado da arte humana, a continuidade do mesmo é assegurada pelo fato que a finalidade inicial permanece a mesma.

Mas a consideração do ajuste da finalidade, não mostra apenas um outro meio pelo qual a imaginação supera a variação e institui uma identidade fictícia. Ela prepara a consideração de uma outra espécie de identidade mais difícil de manter: a dos seres vivos. A dificuldade posta por esses objetos é maior, pois, a variação faz parte de seu próprio desenvolvimento. "Um carvalho," diz Hume, "uma planta que se torna uma imensa árvore, permanece sendo o mesmo carvalho, embora nenhuma partícula de sua matéria e de sua figura permaneça a mesma." (TNH, p. 257) Ocorre, porém, que as partes desses seres não apenas concorrem para um fim comum. Elas apresentam, além disso, uma mútua dependência e conexão, elas são unidas por uma "simpatia". 
Consideradas sobre esse ponto de vista, a relação entre essas partes é tão estreita que "é forçoso admitir que, em poucos anos, vegetais e animais sofrem uma total transformação; mas continuamos a lhes atribuir uma identidade, por mais que sua forma, tamanho e substância se alterem inteiramente." (TNH, p. 257) A variação (geração e corrupção) é inerente aos organismos, mas a simpatia entre suas partes é tal que, a despeito de toda transformação que sofrem, sua identidade é facilmente admitida pela imaginação.

A consideração desses casos revela dois gêneros de confusão. Em primeiro lugar, confundimos a identidade numérica e a identidade específica. Embora sejamos capazes de distinguir essas duas espécies de identidade essa confusão é freqüente e, como, mostra o exemplo de Hume, muito natural quando há uma relação envolvida.

Um homem que escuta um som que se interrompe e recomeça com freqüência diz tratar-se sempre do mesmo som; mas é evidente que os sons têm apenas uma semelhança ou identidade específica e que a única coisa numericamente idêntica é a causa que os produziu. ( $T N H$, p. 258)

Essa confusão oriunda de uma relação que explica por que, muitas vezes, mesmo quando um objeto é inteiramente aniquilado e substituído por outro somos levados a dizer que se trata da mesma coisa. Assim, ainda seguindo os exemplos do texto, podemos compreender as razões pelas quais quando uma igreja é inteiramente destruída e refeita segundo um novo padrão arquitetônico e com materiais inteiramente distintos dos originais, podemos dizer que estamos diante da mesma igreja. Nesse caso a contradição é flagrante, pois, tal fenômeno deveria conduzir-nos a pensar a multiplicidade, e, no entanto, é a identidade que prevalece. O que ocorre aqui é que, embora nem a forma nem a matéria sejam as mesmas, a relação daquela igreja com os habitantes 
da paróquia permanece, e essa relação é suficiente para que a imaginação de curso livre à sua ilusão.

Em segundo lugar, quando estamos diante de objetos cuja natureza, por assim dizer, é fortemente marcada pela inconstância e pela mudança somos alterações súbitas não interrompem significativamente a continuidade do pensamento, nem perturbam a imaginação a ponto de colocar em risco sua identidade.

A natureza de um rio consiste no movimento e na mudança das partes; e, por mais que elas se alterem inteiramente no decorrer de umas poucas horas, nem por isso o rio deixa de ser o mesmo, por diversas gerações. Natural e essencial é aquilo que corresponde a uma expectativa; o que é menos impressionante e parece menos importante que algo inusitado ou extraordinário. ( $T N H$, p. 258)

No caso do rio, como no dos seres vivos, mesmo a mudança súbita não produz quebra na cadeia do pensamento, porque ela é condizente com mutabilidade que observamos nesses objetos. De modo que a variação desses objetos é insuficiente para interromper o curso do pensamento. Não há, portanto, interrupções nas disposições e tendências da imaginação.

Há uma grande analogia entre os casos acima e a ficção da identidade pessoal. Assim, como os produtos da arte humana e as produções da natureza, a mente é marcada por um movimento e uma variação. É essa semelhança que permite a Hume agora passar ao estudo direto do problema da identidade pessoal. Pois a suposição da identidade do eu, assim como a daqueles objetos, implica a superação da contradição entre a variação e a estabilidade, o movimento e a fixidez. "Assim, simulamos a existência contínua das percepções de nossos sentidos, para remover a interrupção, e chegamos à noção de alma, eu, ou substância, para disfarçar a variação." (TNH, p. 254) Ora é essa semelhança que indica um caminho a ser seguido. Com efeito, se 
os dois fenômenos são similares, eles devem ter uma origem similar. Assim, do mesmo modo que ocorria quando conferíamos unidade e identidade a um objeto da arte humana através da consideração de sua finalidade, ou através da simpatia entre as partes quando se tratava de um organismo; ao considerarmos o fluxo mental e a união de nossas idéias na imaginação, deixamos de lado a diferença e a separação dos elementos que o compõem, e atribuímos uma identidade à mente.

A identidade pessoal é fabricada a partir da união de percepções na imaginação. Ela é uma qualidade que lhes atribuímos quando consideramos essa união.

O entendimento humano jamais poderá descobrir alguma conexão entre existências distintas. Apenas sentimos (feel) uma conexão ou determinação do pensamento de passar de um objeto a outro. Segue-se, portanto, que é o pensamento que encontra uma identidade pessoal, quando, ao refletir sobre a cadeia de percepções passadas que compõem a mente, sente que essas idéias e percepções estão conectadas entre si e que introduzem naturalmente umas às outras. (TNH, apêndice, p.635)

Aqui a imaginação estende as conexões que estabelece entre seus objetos, para a própria mente e, assim, fortalece a união entre eles.

Desse modo, tal ilusão é resultado da transição fácil de idéias e, portanto deve-se à ação das relações naturais. Três são os elementos que concorrem para a fabulação da identidade pessoal e para a produção de crença nessa ficção: a semelhança, a causalidade e a memória. Com efeito, a imaginação naturalmente estabelece semelhanças entre percepções passadas e presentes, reforçando a transição de uma idéia à outra e favorecendo a identificação entre a mente e os objetos do pensamento.

Pois o que é a memória, senão a faculdade pela qual despertamos imagens de percepções passadas? $\mathrm{E}$, como uma imagem necessariamente se assemelha a 
seu objeto, não deve a freqüente inserção levar a imaginação mais facilmente de um elo a outro, fazendo o todo se parecer com a continuação de um objeto único? (TNH, p. 260)

Essa idéia de identidade é reforçada e alargada pela ação da relação de causa e efeito. Através dela o feixe de percepções que compõe a mente organiza-se num sistema coeso cuja unidade complexa é comparável á de uma república ou comunidade.

A melhor comparação que eu poderia fazer é da alma com uma república ou comunidade cujos diversos membros estão unidos por laços recíprocos de governo e subordinação, gerando outras pessoas que propagam a mesma república pela transformação incessante de suas partes. E, assim como a mesma república individual pode mudar não só seus membros, mas também suas leis e constituições, assim também a mesma pessoa pode variar seu caráter e disposição, bem como suas impressões e idéias, sem perder sua identidade. ( $T N H$, p. 260)

Ao imprimir ordem e regularidade ao fluxo mental, a causalidade torna possível que, a despeito da variedade e do movimento que caracterizam esse fluxo, ele seja sentido como simples e contínuo. Da mesma forma que ocorre quando atribuímos identidade aos objetos, a transição entre as idéias é tão fácil e suave que temos a impressão de percorrer um objeto simples.

Além disso, como já vimos, a relação causal é o princípio de associação que produz a ligação mais forte e mais extensiva entre seus conteúdos. Pela ação da causalidade somos capazes de conceber algo que não nos é imediatamente dado nem pelos sentidos, nem pela memória. "Ao encontrar um relógio ou qualquer outra máquina numa ilha deserta, um homem concluiria que outros homens já teriam estado naquela ilha." (Investigação p. 27). No que tange à identidade pessoal, 
a causalidade agiria de forma a impedir que as lacunas da memória fossem capazes de destruir a suposta unidade da mente.

Quem poderia me dizer, por exemplo, quais foram seus pensamentos e ações nos dias $1^{\circ}$ de janeiro de 1715, 11 de março de 1719 e 3 de agosto de 1733? Ou será que apenas por ter-se esquecido inteiramente dos incidentes ocorridos nesses dias, afirmará que o eu presente não é o mesmo eu daquele tempo, destruindo assim todas as noções mais bem estabelecidas de identidade pessoal? ( $T N H$, p. 262)

Essa passagem é duplamente ilustrativa. Por um lado, ela mostra o quanto a causalidade é capaz de estender e completar a ficção do sujeito. Por outro, ela aponta para a força com que essa ilusão natural se impõe.

Todavia, não é demais lembrar que ao remeter a idéia de identidade pessoal ao sentimento (feeling) produzido pelos princípios de associação e à transição fácil que eles geram, Hume não legitima a idéia de eu ou pessoa, tal como a filosofia a concebe. O eu nada mais é que uma ficção da imaginação e sua suposta unidade é apenas o resultado de algum "princípio imaginário de união". O sujeito não passa de uma ilusão natural que afeta a todos os homens, mas que os filósofos conceberam equivocadamente como uma substância que opera como suporte de nossas percepções. Cabe a um empirismo rigoroso denunciar essa ilegitimidade.

\section{IV}

O labirinto da identidade pessoal não termina, porém, por aqui. É preciso separar, diz Hume ainda no livro I do Tratado, "a identidade pessoal no que diz respeito ao pensamento e à imaginação, às nossas paixões e ao interesse que temos por nós mesmos." ( $T N H$, p. 265) 0 exame do eu causa embaraços ao filósofo que procura conciliar o 
movimento e a sucessão das percepções com a mais estrita e imutável identidade, mas não ao vulgo que sob o efeito das paixões possui um sentimento forte e vivaz de si mesmo, apesar de experimentar na sua pessoa o mesmo fluxo de percepções. Evidentemente, não se trata de afirmar que esse sentimento não pertence à casta privilegiada dos filósofos, mas apenas que a reflexão intensa pode obscurecê-la momentaneamente, mergulhando o pensador num estado momentâneo de, na expressão do autor, "melancolia e delírio".

Mas como é possível que, quando analisada do ponto de vista da imaginação e do pensamento a identidade pessoal se dissipe numa coleção de idéias e impressões, e quando do ponto de vista das paixões o eu nos seja sempre intimamente presente? É ao longo do estudo do orgulho e da humildade que a natureza dessa idéia se revela mais claramente. Diferentemente das chamadas paixões diretas - derivadas imediatamente das sensações de prazer e dor - orgulho e humildade são causados apenas indiretamente por essas duas sensações, e envolvem uma dupla associação entre idéias e outras paixões. A alegria, por exemplo, pode suscitar o amor, a piedade, a generosidade, a coragem, e, por fim, o orgulho. Essa transição de uma paixão à outra será tanto mais fácil quanto mais for assistida por uma associação de idéias.

Assim, um homem cujo temperamento foi fortemente perturbado e abalado por uma ofensa encontra uma centena de motivos de desgosto, impaciência, medo e outras paixões desagradáveis, sobretudo se puder encontrá-los na pessoa que causou sua primeira paixão ou em algo próximo a ela. (TNH, p. 284)

Além disso, nas paixões indiretas é preciso distinguir dois elementos: um objeto e uma causa da paixão. O objeto designa somente a idéia para a qual essas paixões "dirigem o seu olhar". Em se tratando do orgulho e da humildade, o ponto no qual a paixão fixa seu 
interesse é sempre o eu: "é evidente que o orgulho e a humildade, embora diretamente contrários, têm um mesmo objeto. Esse objeto é o eu, ou aquela sucessão de idéias e impressões relacionadas, da qual temos intima memória e consciência." (TNH, p. 277) Esse esquema sucinto permite explicar por que sou naturalmente afetado pelo orgulho ou pela humildade quando tenho em mente, por exemplo, minha família, meus bens, meus amigos e meu país. Todos se tornam objeto dessas duas paixões na medida em percebo uma relação tão estreita entre eu e eles, que chego a associar de alguma forma suas qualidades à minha pessoa.

Um belo peixe no oceano ou um formoso animal na floresta, ou qualquer coisa que não nos pertença nem esteja relacionada conosco não exerce nenhuma influência em nossa vaidade, quaisquer que sejam as qualidades extraordinárias de que ela é dotada e qualquer que seja o grau de surpresa que ela possa naturalmente ensejar. (Dissertação sobre as paixões, p. 143)

A paixão do orgulho é agradável, e a da humildade é dolorosa. Ambas são, nesse sentido, afetos opostos e não poderiam, sem contradição, ser efeitos das mesmas causas. Daí a distinção entre a causa e o objeto dessas afecções. Mas, se o objeto desse par de afeç̧ões é único, suas causas são múltiplas e implicam uma segunda subdivisão. Essa segunda distinção refere-se ao sujeito e à qualidade da causa. Esses dois elementos permitem explicar o mecanismo que engendra a paixão indireta. É preciso, em primeiro lugar, que a qualidade da causa seja agradável ou dolorosa, para que ela suscite paixões agradáveis ou dolorosas. Em segundo lugar, é necessário que o sujeito da causa esteja ligado, por associação de idéias, ao objeto da paixão. Assim, uma casa belamente projetada pode ser fonte do orgulho de seu proprietário. Posso identificar aqui uma qualidade (beleza) que associada a um sujeito (casa) excita essa paixão. Posso identificar, 
também, que o objeto dessa paixão (o proprietário da casa) está ligado à causa da mesma por associação de idéias. É justamente esse mecanismo que implica uma dupla associação de idéias e impressões.

A causa que suscita a paixão está relacionada com o objeto que a natureza atribuiu à paixão; a sensação que a causa produz separadamente está relacionada com a sensação da paixão. Uma idéia se converte facilmente em sua idéia correlata; uma impressão, em outra que se assemelha e corresponde a ela. Quão mais fácil não deve ser a transição quando esses movimentos se auxiliam mutuamente e quando a mente recebe um duplo impulso de suas relações de impressões idéias?" (TNH, pp. 286-287).

Mecanismo causal complexo, a produção das paixões indiretas, no caso orgulho e humildade, depende da ocorrência desses dois gêneros de associação. Contudo, uma vez as duas associações concorrem naturalmente no mesmo objeto, elas se auxiliam reciprocamente facilitando a transição tanto dos afetos quanto da imaginação.

Mas resta que a idéia do eu, à qual ambos se referem, é sui generis, para não dizer problemática. Afinal, como mostrou a longa análise que Hume faz da identidade pessoal, ela não possui impressão de sensação correspondente e consiste numa ilusão natural. O problema é que, conforme a expressão simples e precisa de Michel Malherbe, "o eu que a paixão tem por objeto não é um objeto real(... $)^{170}$." Por isso, esse eu não é antecede à paixão, nem integra os elementos que compõem sua causa: ele é um produto de orgulho e humildade.

Mas como é possível que duas paixões produzam tal idéia? A resposta é desconcertantemente simples: é natural que seja assim.

Os nervos de nossos órgãos sensíveis estão dispostos de maneira a transmitir à mente, em determinadas circunstâncias, sensações peculiares. As sensações de

170 Malherbe, La Philosophie Empiriste de David Hume, p. 177. 
fome e desejo carnal sempre produzem em nós a idéia dos objetos peculiares a cada apetite (TNH, p. 253)

De modo semelhante, os "órgãos da mente humana" possuem uma disposição natural para produzir um o orgulho e a humildade, quando esses afetos são excitados, a idéia do objeto que lhes corresponde é naturalmente produzida. E não é apenas isso. Se no plano da imaginação e do pensamento, o eu era uma ilusão natural cujo caráter fictício a análise empirista se encarregava de expor, considerada do ponto de vista dos afetos essa idéia possui um grau superior de força e vivacidade, derivado da própria operação das paixões. Na produção dessa ilusão natural, a força das paixões vem somar-se a das relações de causalidade e semelhança. Embora a idéia do eu seja uma ficção, ela é uma das mais fortes e vivas.

É evidente que como estamos a cada momento intimamente conscientes de nós mesmos, de nossos sentimentos e paixões, as idéias destes devem nos tocar com maior vivacidade que as idéias dos sentimentos e paixões de qualquer outra pessoa. (Tratado da natureza humana, p.253)

Nesse terreno, o eu tem um sentido próprio; ele se refere exclusivamente aos sentimentos e paixões, à consciência de mim mesmo e ao interesse que nutro pela minha pessoa.

\section{V}

Consideradas em conjunto, as análises da crença nos objetos externos e no eu representam um golpe duro contra a tradição, desde os antigos até os modernos. Em ambas as análises, a despeito dos diferentes percursos que o objeto de cada uma obriga Hume a seguir, resultados semelhantes são obtidos. As ficções em torno das quais a 
metafísica articula seu discurso não resistem ao exame empirista e à evidência da diferença e da separação de nossas percepções.

Uma vez revelado jogo de ilusões que está na base de seu saber, como responder ao metafísico, a não ser através do humor? Assim, quando o filósofo procura defender a tese de que há um sujeito imutável em meio à variação do pensamento e das impressões, cabe apenas retorquir com a hipótese absurda de que talvez ele seja de um gênero diferente dos outros homens, capaz de perceber "algo simples e contínuo, que ele chama de ele mesmo (himself) ${ }^{\prime 171}$.

As conseqüências dessa filosofia não são exatamente perniciosas para o conhecimento e para a moral. Afinal, se o filósofo humiano nega a possibilidade de uma legitimação filosófica da existência do eu e das existências externas e mostra toda a fabulação que subjaz à metafísica, é para no momento seguinte explicar a produção das crenças naturais que estão na base dessas ficções e render-se a elas.

Esse parece ser, ao menos em parte, o sentido da conclusão do livro I do Tratado. Com efeito, a situação de desespero que Hume descreve nas linhas iniciais da conclusão, as desconfianças em relação à razão e ao entendimento, o retrato do filósofo jogado à melancolia pelas conclusões às quais seu argumento o levou, são logo amenizados pela satisfação de quem sabe que "sendo a razão incapaz de dissipar essas nuvens, a natureza da conta desse propósito", livrando-o da "melancolia e delírio filosóficos". Assim, ainda que nunca desapareça totalmente, aquela disposição inicial para o ceticismo se arrefece e o filósofo angustiado dá lugar ao homem que janta, conversa, joga gamão e persevera numa "crença indolente nas máximas gerais do mundo ${ }^{172 " .}$

${ }^{171}$ Cf. $T N H$, p. 252.
172 Cf. $T N H$, p. 269. 
Ora, Hume não se considera um cético pirrônico, mas professa um ceticismo mitigado, descreve a si mesmo como um cético descuidado ${ }^{173}$. Seria absurdo afirmar, por exemplo, que o filósofo escocês nega a existência de objetos externos. Como assinala Lebrun, esse aspecto mostra bem o ponto de dessemelhança entre o filósofo escocês e o padre irlandês. Pois, se Berkeley atribuía falácia da existência externa a um erro derivado do caráter involuntário de nossas idéias sensíveis, Hume recusa essa caracterização do problema e esse termo (erro) em sua análise. Segundo Lebrun, para Berkeley o problema da dupla existência está na resposta dada a uma questão que se impõe de forma legítima a qualquer filósofo, enquanto Hume nega a própria pertinência da pergunta ${ }^{174}$. A análise de Hume não é acerca de um erro filosófico, mas sobre uma ilusão natural. A diferença aqui é que se a questão é posta nos termos do erro, admite-se de antemão a possibilidade de sua correção. Colocada em termos de "ilusão natural" o caso é bem diferente. Afinal, uma ilusão desse gênero não se corrige. Mesmo que ela não seja passível de justificação ela é objeto de crença. Somos determinados a crer na existência dos corpos e na existência do eu, assim como éramos determinados crer na idéia do efeito ausente quando estamos diante de sua causa.

No caso específico dos corpos, trata-se de uma crença inevitável, cuja persuasão irresistível é atestada paradoxalmente pelas tentativas da filosofia de retificá-la, através da noção da separação entre objeto e

\footnotetext{
${ }^{173} \mathrm{Cf}$. TNH, I, 4, 8, p. 273: "A conduta do homem que estuda filosofia de maneira descuidada é mais verdadeiramente cética do que a daquele que, mesmo sentindo em si uma inclinação para uma tal conduta, está tão cumulado de dúvidas e escrúpulos, que a rejeita."

${ }^{174}$ Cf. Lebrun, Berkeley ou Le Sceptic Malgré Lui, In: A Filosofia e sua História, p. 421: "De fato, ao seguir esse caminho, o filósofo necessariamente se veria em busca de uma causa que não poderia ser determinada pelo bom método causal. Qual é a causa da maior parte das sensações que experimento e das quais não sou o autor? Qual é a causa da constância das aparências que eu não criei? Para Hume essas questões são inúteis, e não é por que os homens as formularam, mesmo que implicitamente, que então forjaram a existência contínua. Para Berkeley, essas questões são legítimas _e se os filósofos se enganaram na determinação da causa não erraram em procurá-la, uma vez que há efetivamente 'alguma causa dessas idéias, da qual elas dependem e que as produz e modifica'."
} 
percepção. Por isso, não cabe ao filósofo humiano corrigir um mal entendido sobre a existência dos corpos ou mesmo duvidar desse fato. Essa última possibilidade Hume exclui desde o início da seção Do Ceticismo sobre os Sentidos, quando afirmava ser "inútil perguntar se existem ou não corpos". Com efeito, como indica Lebrun, para Hume simplesmente não temos "o poder de decidir" a esse respeito.

Essa é a "lição" que uma passagem curiosa dos Diálogos sobre a Religião Natural nos transmite. A certa altura, Filo - que demolira a legitimidade lógica do argumento finalista da existência de Deus - vacila ante a uma nova formulação do argumento teísta, apresentada por seu amigo Cleantes. A manobra de Cleantes é simples e engenhosa. Tratase de mostrar ao cético que ele pôs um acento exagerado na importância das condições lógicas da prova a posteriori ao mostrar que a prova teísta, baseada na analogia entre as produções da arte humana e os produtos da natureza, infringe as regras da analogia. Filo peca porque despreza a maneira como a semelhança entre esses termos nos atinge.

Mas de modo algum é necessário aos teístas provar as similaridades entre os trabalhos da natureza e os da arte, pois essa semelhança é auto-evidente e inegável. A mesma matéria, uma forma semelhante; o que mais é requerido para mostrar a analogia entre suas causas e para comprovar que todas as coisas têm sua origem no propósito e intenção divinos? (DRN, p.54).

O mundo e os produtos da arte são da mesma matéria e apresentam uma forma semelhante; essa similaridade decerto não é perfeita, mas é suficiente para que o argumento conserve produza convicção. Com essa manobra, Cleantes conduz a discussão para o âmbito do feeling e da crença. E sob ponto de vista, a ordem do mundo levaria naturalmente à idéia da teleologia. Não por acaso, agora o teísta poderá dizer que a relação entre a ordem e a finalidade nos atinge com a "força de uma 
sensação". Trata-se de um argumento de "natureza irregular", reconhece Cleantes, mas nem por isso menos convincente. Ante essa mudança de registro Filo silencia.

Além de prenunciar o conhecido desfecho da obra, esse lance dramático dos Diálogos ilustra bem a posição de Hume tanto em relação aos céticos quanto aos dogmáticos. Trata-se de tornar sensível ao leitor o fato de que, embora uma tese possa e deva ser considerada com vistas à sua validade, não é por uma crítica racional que, no fim das contas, me decido conceder ou negar meu assentimento a uma argumentação. Com o silêncio de Filo e a astúcia de Cleantes, Hume nos indica que a crença não é tributária somente do argumento. Vimos que ela é produzida de diferentes modos e diz respeito aos graus de força e vivacidade com que uma idéia é concebida. A mente, afetada pela diferença de graus, admite ou não a realidade de uma idéia ou proposição: "eu concluo, por uma indução que me parece muito evidente, que uma opinião ou crença não é senão uma idéia que é diferente da ficção, não pela natureza ou pela ordem de suas partes, mas pela maneira de ser concebida." (TNH, apêndice, p. 628)

$O$ ceticismo conseqüente aceita esse fato. $O$ cético radical e o dogmático o negam, pois a despeito das diferenças aparentes eles têm em comum um racionalismo exacerbado. Como diz Hume, "a única diferença entre estas duas seitas, se é que elas merecem este nome, é que o cético, por hábito, capricho ou inclinação, insiste mais nas dificuldades; o dogmático, por razões semelhantes, insiste na necessidade." (DRN, p. 120) O verdadeiro ceticismo não compartilha do apego desmesurado à razão. Quando Hume denuncia que o vocabulário e o arsenal conceitual da metafísica são tributários de ilusões naturais, é para corrigir a filosofia, não as crenças naturais. Essas, ele jamais procurará justificar. Mas nem por isso poderá anulá-las pela a dúvida, do cético pirrônico ou do filósofo cartesiano. 


\title{
Capítulo V - A Uniformidade da Natureza Humana
}

\begin{abstract}
I
É na discussão acerca da liberdade e da necessidade que se pode observar como Hume instaura um paradigma de conhecimento que torna possível a ciência da natureza humana, bem como quais são os conceitos e operações que viabilizam a formulação de seu novo modelo de ciência. A questão da liberdade oferece a Hume a oportunidade perfeita para expor as conseqüências desse novo conceito de necessidade e demonstrar a viabilidade da ciência da natureza humana. Pois, a princípio, nada colocaria mais em risco a possibilidade dessa ciência que a admissão de uma indiferença ou indeterminação das ações humanas.
\end{abstract}

Como poderia a política ser uma ciência, se as leis e formas de governo não exercessem uma influência uniforme sobre a sociedade? Onde estaria o fundamento da moral, se caracteres particulares não tivessem um poder certo ou determinado de produzir sentimentos particulares, e se estes não operassem de forma constante nas ações [dos homens]? (Investigação, p.90)

Ora, a moral, a política e a crítica versam sobre questões de fato. E o conhecimento dos fatos deriva da relação de causa e efeito. Aceitandose o livre-arbítrio estaríamos introduzindo uma indeterminação que nos impossibilitaria de produzir inferências causais acerca das ações. No Tratado e na Investigação sobre o Entendimento Humano, ao retomar a antinomia entre liberdade e determinação, Hume mostra ao leitor que desde o comentário da causalidade já estavam dadas as condições de possibilidade dessa filosofia, e indica as feições da ciência da natureza humana. Com efeito, a análise daquela relação não consistia apenas na recusa da interpretação que o metafísico forjava para a conexão causal, mas tinha como principal resultado uma redefinição de necessidade. 
Essa nova definição de não oferece apenas uma solução para a controvérsia acerca da liberdade, como assegura a possibilidade de uma filosofia moral fundada no método experimental.

\section{II}

Qual é o feitio dessa solução? De que forma ela resolve a polêmica entre os defensores da liberdade e os da necessidade e abre perspectivas para a ciência da natureza humana? Comecemos por seguir a argumentação da Investigação para responder a essas perguntas. Há discussões, conforme explica Hume logo no início da seção VIII, que se devem muito mais a alguma ambigüidade de expressão do que a uma divergência real de opinião. E questões dessa espécie podem ser resolvidas através de uma simples clarificação dos termos, assinalando quais idéias correspondem às palavras empregadas por cada uma das partes ${ }^{175}$. Ora, o debate acerca da liberdade se inclui entre esses tópicos.

Tal é o caso da tradicional e polêmica questão acerca de liberdade e necessidade. $E$ ou muito me engano ou descobriremos que o gênero humano como um todo, incluindo doutos e ignorantes, foi sempre da mesma opinião a respeito desse tópico, e umas poucas definições imediatamente inteligíveis bastariam para encerrar a controvérsia. (Investigação, p.81)

Embora não o vejam com clareza não só os doutos concordam entre si, como concordam com o restante da humanidade. Posto desse modo, o comentário humiano da liberdade e da necessidade parece antes de

\footnotetext{
${ }^{175} \mathrm{Cf}$. Investigação, p. 81: "É verdade que quando os homens enveredam pela discussão de questões que jazem inteiramente fora do alcance das capacidades humanas, como a origem dos mundos, ou a economia do sistema intelectual ou região dos espíritos, eles podem perder seu tempo golpeando o ar em suas contendas infrutíferas sem nunca chegar a nenhuma conclusão. Mas, se a questão diz respeito a algum assunto da vida comum e da experiência, é de supor que tudo o que poderia manter indefinida a disputa são expressões ambíguas que separam os antagonistas e os impedem de se engalfinharem."
} 
tudo pacificador. Pois, para dissipar a discórdia bastaria apenas mostrar a ambas as partes que, sem percebê-lo, estavam de acordo o tempo todo.

Mas o que significa exatamente afirmar que todos os homens possuem uma mesma noção de liberdade e de necessidade? O ponto de partida para responder a essa questão está na retomada da idéia necessidade lá aonde ela se apresenta com maior clareza e não comporta controvérsias:

Admite-se universalmente que a matéria é impelida, em todas as suas operações, por uma força irresistível, e que os efeitos naturais são tão precisamente determinados pela energia de sua causa que, naquelas circunstâncias particulares, nenhum outro efeito poderia resultar dela (...) Se quisermos, portanto, formar uma idéia correta e precisa de necessidade, devemos considerar de onde vem essa idéia, quando a aplicamos ao movimento dos corpos. (Investigação, p. 82)

É universalmente admitido que o movimento dos corpos deriva de causas necessárias. Todavia, ainda que haja acordo quanto ao império da necessidade nesse âmbito, é fundamental recuperar o verdadeiro significado do termo necessidade. É preciso lembrar o leitor de que se está diante de uma nova definição desse conceito. Assim, Hume retoma o exame da causalidade de forma a mostrar que: "Além da conjunção constante de objetos semelhantes e da conseqüente inferência de um a partir do outro, não temos nenhuma noção de qualquer necessidade ou conexão." (Investigação, p. 82) Ao contrário do que poderia sugerir a primeira apresentação da necessidade _exposta propositalmente em termos caros à metafísica (poder e energia) de modo a reforçar a tese da determinação das causas_ essa idéia não corresponde a nada fora da mente. A necessidade é um efeito da repetição da experiência de casos 
semelhantes sobre nossas mentes, ela é resultado do hábito e da uniformidade da natureza.

\begin{abstract}
Portanto, nossa idéia de necessidade e causação deve-se inteiramente à uniformidade observável nas operações da natureza, quando objetos semelhantes estão constantemente conjugados e a mente é determinada pelo costume a inferir um a partir da aparição do outro. (Investigação, p. 82) 176 $^{17}$
\end{abstract}

Em outras palavras, a repetição de seqüências observável na experiência afeta a imaginação fazendo-a ligar conteúdos que se seguem regularmente. Assim, o princípio que está na base da razão experimental não é, ele mesmo, um princípio propriamente racional ${ }^{177}$. Ele é, isto sim, relativo ao sentimento (sentiment) e, nessa medida, é inadequado para fornecer a razão última pela qual duas naturezas distintas são postas em relação na imaginação ${ }^{178}$. A conexão costumeira é sentida pela imaginação e a impressão de reflexão que ela produz é que leva essa faculdade a ligar os conteúdos empíricos.

Com essa nova definição, é possível divisar como Hume pretende eliminar a controvérsia verbal acerca da liberdade. Se a necessidade nos é dada pela conjunção constante, se ela não é um vínculo interno que conecta a causa e o efeito, é possível afirmar que ela é determinável também nas ações humanas. Hume não se cansará de afirmar que há

\footnotetext{
176 Quanto à origem da idéia de necessidade, vale lembrar a seguinte passagem: "A conexão que nós sentimos (feel) na mente, a transição costumeira da imaginação, de um objeto para o seu acompanhante (attendant) usual é o sentimento (sentiment) ou impressão a partir do qual formamos a idéia de poder ou conexão necessária." (Investigação, p. 75)

${ }^{177}$ Note-se que na seção IX da Investigação, intitulada Da Razão dos Animais, Hume conclui que "o próprio raciocínio experimental, que temos em comum com as bestas e do qual depende toda a condução da vida, é apenas uma espécie do instinto ou poder mecânico que atua incógnito sobre nós e que em suas principais operações não é dirigido por nenhuma daquelas relações ou comparações de idéias que são o objeto próprio de nossas faculdades intelectuais." (Investigação, p. 108)

${ }^{178}$ Como afirma Malherbe: "Fazer do hábito um princípio de inteligibilidade é, portanto, falsear a análise humiana. Ele causa a inferência, mas a essência da causa resta obscura, e não é dele que se tira o efeito." (La Philosophie Empiriste de David Hume, p. 124)
} 
uma grande uniformidade nas ações dos homens em todas as épocas e nações e que a natureza humana permanece sempre a mesma em seus princípios e operações. Os mesmos motivos produzem sempre as mesmas ações: os mesmos eventos se seguem às mesmas causas. (Investigação, p. 83)

Raciocinamos em moral do mesmo modo que em todas as outras questões de fato. É pela conjunção constante entre o par motivo/ação que podemos prever o comportamento humano e isolar seus princípios. Quando se trata de estudar os assuntos humanos, de fazer uma filosofia moral, pensamos da mesma maneira que o fazemos quando nos dedicamos às outras ciências sobre os fatos. E mesmo o vulgo, quando pensa sobre esses temas, o faz quase que da mesma maneira que o filósofo e o cientista, como já indicava o início da seção 8 . A inferência causal, em todos esses casos é de mesma natureza, e a necessidade que a mente sente de passar de um objeto a seu acompanhante usual tampouco é diferente. Tal como ocorria no caso dos objetos físicos, ao considerar os assuntos morais pressuponho uma certa uniformidade da natureza em meus raciocínios.

É, portanto, a mesma a mesma necessidade que preside minhas inferências seja na moral, seja no que concerne à causalidade dos corpos. Não há diferença de natureza entre os dois supostos gêneros de conexão. Melhor dizendo, não cabe mais postular dois gêneros distintos de necessidade, pois "Existe um curso geral da natureza nas ações humanas, assim como nas operações do sol e do clima." (TNH, p. $402)^{179}$ Por isso, não só é a mesma necessidade que opera sobre a mente em ambos os casos, mas também é possível empregar a evidência moral e a evidência física num mesmo raciocínio. Assim, tem razão o prisioneiro que, não possuindo dinheiro ou influência, está certo de que não conseguirá escapar de sua pena, considerando o caráter 
obstinado do carcereiro que o guarda em pé de igualdade com a solidez das barras e muros que tornam a prisão intransponível ${ }^{180}$.

Mas se todos compreendem a ação sob a sombra da necessidade e da uniformidade, é preciso explicar como forjamos a idéia de liberdade. Mais que isso, por que somos levados a defender a tese da liberdade de indiferença, segundo a qual a vontade teria autonomia em relação a seus motivos e poderia decidir-se até mesmo a desconsiderá-los na escolha de uma ação. Essa operação possui duas etapas a serem explicitadas. Em primeiro lugar, ela deriva do apego que os homens demonstram em relação à noção metafísica da causalidade e à convicção de que têm acesso a algo como um poder real das causas. As "pessoas acreditam que penetram mais profundamente na natureza e que percebem algo como uma conexão necessária entre a causa e o efeito" (Investigação, p. 92). Essa primeira crença dá as condições para que se cumpra a segunda etapa da produção dessa fiç̧ão.

A liberdade de indiferença nada mais é que o complemento exigido por essa concepção da necessidade, exigida pelo fato de que ao agirmos muitas vezes não percebemos a relação entre a ação e os motivos que nos levaram a realizá-la. Isso é especialmente verdadeiro quando se trata de nossas próprias ações e, por isso, um argumento baseado na introspecção será invocado em favor da liberdade.

Em contrapartida, liberdade ou acaso não é senão a falta dessa determinação, uma certa frouxidão (looseness) que sentimos ao passar ou não da idéia de um objeto àquela da ação. Ora, podemos observar que embora ao refletir sobre as ações humanas raramente nós sentimos uma tal frouxidão ou indiferença, é muito comum que ao realizarmos as próprias ações tenhamos a sensibilidade de algo assim. (TNH, p. 408)

\footnotetext{
${ }^{179}$ Sobre isso cf. também, Investigação, p. 91: "A mesma união experimentada tem o mesmo efeito sobre a mente, sejam os objetos unidos volição e ações ou figura e movimento."
} 
É porque esposamos uma noção de causa calcada num "esquema energético", segundo a expressão de Lebrun, que somos levados a pensar a liberdade ${ }^{181}$. Quando esse esquema parece falhar introduzimos a seu lado o livre-arbítrio como contraparte da determinação causal, de modo harmonizar as rupturas na conexão necessária e preservar o restante da série.

Ora, se há liberdade, mostrará Hume na Investigação, essa não é a liberdade de indiferença. A única noção de liberdade que os homens empregam de fato em seus raciocínios é aquela da qual são dotados todos os homens, exceto o "prisioneiro acorrentado ${ }^{182 " . ~ T r a t a-s e ~ d a ~}$ liberdade que se opõe à restrição ou à coação, e não à necessidade ${ }^{183}$. $E$, de fato, se a "frouxidão" das conexões, que sentimos ao observar nossos próprios atos, pode dar a ilusão de uma indiferença da vontade em relação aos motivos que determinam a vontade, em nossos raciocínios comuns não é de acordo com essa fiç̧ão que pensamos. Sempre consideramos a ação do ponto de vista da conexão regular que fundamenta nossos raciocínios sobre quaisquer questões de fato. E é bom que seja assim, pois, a liberdade de indiferença destruiria por completo essa necessidade ao abrir espaço para o acaso nas questões de fato.

Se alguém pudesse definir causa sem incluir uma conexão necessária com um efeito e mostrasse de maneira distinta a origem da idéia que essa definição expressa, eu abriria mão da controvérsia. (...) Mas, se a definição supracitada é admitida, então liberdade, oposta à necessidade, não à coação, é o mesmo que acaso - algo que, como todos sabem, não existe. (Investigação, pp. 95-96)

\footnotetext{
${ }^{180}$ O exemplo ocorre, como se sabe na Investigação, p. 90.

${ }^{181}$ Cf. Lebrun, A Boutade de Charing-Cross, In: A Filosofia e sua História, p. 147.

182 Sobre isso, cf. Investigação, p. 95.

183 Sobre isso, cf. Investigação, p.96.
} 
A causalidade não pode ser definida sem o recurso à necessidade. Assim, manobras como a de Clarke, que distinguia a necessidade física da necessidade moral, pensando salvaguardar espaço tanto para a causalidade física quanto para a autonomia da vontade humana e divina, não fazem senão introduzir o acaso nos domínios da ação e da física ${ }^{184}$.

Vê-se então que solução para a controvérsia acerca da liberdade não é exatamente apaziguadora. Com efeito, "projeto de reconciliação" proposto por Hume certamente não chega a agradar nenhum dos dois partidos envolvidos na disputa. Pois, ele demanda ao partidário da liberdade reconheça que sua idéia de livre-arbítrio deriva de um apego exagerado à tese da necessidade das causas. Que a liberdade que defende é ilusória porque é elaborada em contraste com a tese igualmente ilusória de que a necessidade física é uma necessidade real, inscrita na natureza dos objetos.

A nova definição de necessidade proposta por Hume, também, desagradará ao determinista, pois, ela iguala a necessidade física e a necessidade moral. E agora, decerto não faltará quem possa acusar Hume de ter rebaixado a primeira, em favor da segunda. Com efeito, o próprio autor do Tratado é o primeiro a reconhecer que "é possível encontrar algumas ações que não parecem ter nenhuma conexão regular com quaisquer motivos conhecidos, exceções a todos os padrões de conduta estabelecidos para o governo dos homens." (Investigação, p.86) E mais, Hume admite que mesmo a necessidade dos corpos admite variações desse gênero ${ }^{185}$. Em outras palavras, se a homogeneização da necessidade física e da necessidade moral foi

\footnotetext{
${ }^{184}$ Sobre a distinção entre esses dois gêneros de necessidade em Clarke cf. Harris, Of Liberty and Necessity, pp. 50-51.

${ }^{185}$ Sobre isso cf. Investigação, p. 86: "Nem sempre as causas são conjugadas a seus efeitos usuais com uma mesma uniformidade. Um artífice que manipula matéria inanimada pode ter frustrados seus objetivos tanto quanto um político que orienta a conduta de agentes sensíveis inteligentes."
} 
possível, foi porque a análise humiana da causalidade enfraqueceu a primeira.

Mas essa crítica só é possível se nos mantemos aferrados à idéia de conexão necessária, tal como foi concebida pelo filósofo racionalista. Vista sob essa perspectiva a necessidade das causas baniria o contingente do território das questões de fato. E seria lícito descrever o conhecimento, como queria Descartes, como a recuperação dos nexos necessários entre os elementos simples que compõem os objetos da experiência, desconsiderando aquelas relações tidas como acidentais ou contingentes ${ }^{186}$.

Todavia, como já mostramos, Hume recusa essa dicotomia entre o necessário e o contingente ${ }^{187}$. Ora, é justamente porque não há ligações internas entre os objeto, porque tudo que sabemos da conexão causal é que ela é apenas a conjunção constante entre dois objetos, que essa oposição não será legitimada na filosofia humiana. No lugar dessa clivagem rígida, que distingue dois territórios incomunicáveis, Hume nos propõe uma gradação que vai das seqüências causais mais perfeitamente uniformes às menos uniformes.

Parece então que a conjunção entre motivos e ações voluntárias é não somente tão regular e uniforme quanto aquela que existe entre causa e efeito por toda parte na natureza, mas também que essa conjunção é universalmente reconhecida pelos homens e nunca foi de fato um objeto em disputa, seja em filosofia, seja na vida ordinária. (Investigação, p. 88)

Assim, não se trata de enfraquecer a necessidade física. Pois, seja na física, seja na moral a evidência poderá ser mais forte ou mais fraca. Dito de outra forma, uma é tão forte quanto a outra.

\footnotetext{
${ }^{186}$ Sobre isso, cf. Descartes, Regras para a Direção do Espírito, regra XII, p. 74.

${ }^{187}$ Cf. Lebrun, A Boutade de Charing-Cross, In: A Filosofia e sua História, pp. 149-151.
} 
Dissipar a distinção entre necessidade física e necessidade moral não põe, portanto, em risco a possibilidade do conhecimento acerca das questões de fato. Não há um enfraquecimento da uniformidade da natureza e, conseqüentemente, das leis naturais. O que se reconhece é apenas que no domínio dos fatos o conhecimento oscila do mais ao menos provável. E a oscilação será tanto maior conforme a complicação de causas envolvida no objeto em questão. O que, diga-se de passagem, já estava implícito desde que Hume dividira o campo do saber em questões de fato e relações de idéias.

A regularidade ou irregularidade dos fenômenos não deriva da natureza dos objetos em questão. É por isso, que no Tratado, ao retomar o vocabulário lockiano que distingue entre conhecimento e probabilidade, Hume pode subverter essa distinção e introduzir uma subdivisão no campo das probabilidades: as provas. Provas e probabilidades em nada diferem a não ser no fato de que as primeiras exibem uma constância e uma uniformidade superiores às segundas. Assim quando se trata de responder à objeção segundo a qual a homogeneização dos dois gêneros de necessidade foi realizada em prejuízo da necessidade física Hume poderá retomar essa modulação nos seguintes termos:

A isso eu respondo, que ao julgar as ações humanas devemos proceder com base nas mesmas máximas com as quais raciocinamos acerca dos objetos externos. Quando dois fenômenos se apresentam em conjunção constante e invariável eles adquirem uma conexão tal na imaginação que esta passa de um ao outro sem qualquer dúvida ou hesitação. Abaixo desse grau, porém, há diversos outros, inferiores em probabilidade e evidência: uma contrariedade da experiência não é suficiente para destruir o nosso raciocínio. ( $T N H$, p. 403)

A inconstância de certos fenômenos não nos revela uma distinção essencial entre eles e aqueles que são mais regulares. Não se trata de 
afirmar que uns são necessários e outros contingentes ${ }^{188}$. Ela apenas indica que precisamos ser mais cuidadosos em seu exame e buscar por circunstâncias e causas que tenham produzido resultados inesperados.

Aí se localiza aquela que deve ser a diferença de atitude entre o filósofo experimental e 0 homem comum. Diante de resultados imprevistos o vulgo julgará estar diante de causas incertas e lançará mão da contingência para explicar o sucedido. Lá onde o resultado é incerto, o senso comum vê causas incertas e contingentes. O filósofo humiano, por seu turno, irá proceder de modo bem diferente. Em vez de explicar a inconstância pela contingência e pelo enfraquecimento da necessidade, ele supõe haver nesse caso uma "operação secreta de causas contrárias", as quais devem ser identificadas mediante "observações adicionais" daquele fenômeno, "[elas] que convertem a possibilidade em certeza quando se nota, após cuidadoso exame, que a disparidade nos resultados revela uma disparidade nas causas e deriva de sua mútua oposição. (Investigação, p. 87) Por isso, é importante para a filosofia humiana explorar o raciocínio acerca das probabilidades. Pois, são principalmente as probabilidades relativas às causas que nos ensinam a lidar com a contrariedade de experiências, sempre preferindo o efeito habitualmente esperado, sem com isso negligenciar outros efeitos possíveis.

Essa contrariedade não introduz a contingência ou o acaso em seu campo de fenômenos. Ela apenas nos indica que é preciso realizar uma análise mais detida dos fenômenos, conforme seu grau de complexidade. É por isso que entre as Regras para se Julgar sobre

\footnotetext{
${ }^{188}$ Cf. Lebrun, A Boutade de Charing-Cross, In: A Filosofia e sua História, p. 154: "Observar que o 'fogo sempre queimou' e que o 'ruibarbo nem sempre tem efeito purgativo' não é retornar de modo algum à dissociação entre necessário e acidental, é apenas constatar que há seqüências causais mais bem recortadas, e outras mal recortadas: as primeiras coincidem com a operação regular de uma causa; as segundas são tais que ainda não se conseguiu localizar, ' na mistura das causas', um fator capaz de agir com regularidade. O provável é o campo dessa necessidade com interrupções, embora de modo algum enfraquecida (itálicos do autor)."
} 
Causas e Efeitos consta a prescrição segundo a qual devemos sempre ter em mente que se dois objetos semelhantes possuem efeitos distintos, deve haver alguma diferença entre eles que nos passou desapercebida. Pois, "tal irregularidade procede de alguma diferença entre as causas." (TNH, p. 174) De certa forma, essa exigência já era conhecida de algumas ciências. O médico, por exemplo, não recua diante do fato de que o remédio prescrito a um doente não surtiu efeito. Ele tem plena consciência de que o corpo humano é uma "máquina imensamente complexa" onde podem agir causas ocultas, até o momento ${ }^{189}$.

\section{III}

Mas, ainda que admitamos que a homogeneização da causalidade física e da causalidade moral não torna as ciências mais precárias, é preciso olhar melhor para as conseqüências dessa uniformização da necessidade. É preciso determinar com mais clareza as feições gerais da ciência da natureza humana que emerge daí. Essa maneira de considerar a ciência do homem, implica um certo deslocamento de ponto de vista quando aplicada ao campo moral. Em vez de considerar a vontade em abstrato e, por vezes, recorrer à introspecção para buscar uma evidência empírica da liberdade da vontade como fazia, por exemplo, Clarke ${ }^{190}$, é como simples observador da ação humana que procura detectar regularidades, que o filósofo humiano se coloca. Como observa James A. Harris, em seu Of Liberty and Necessity, essa mudança de perspectiva já está implícita desde o momento em que, no Tratado, Hume apresentava a vontade como "nada além da impressão interna que sentimos e da qual somos conscientes quando deliberadamente damos início a um novo movimento do corpo ou a uma

\footnotetext{
189 Cf. Investigação, p. 87.

${ }^{190}$ Sobre isso, cf. Harris, Of Liberty and Necessity, 2, pp. 46-48.
} 
nova percepção em nossa mente. (TNH, p. 399) Definida nesses termos, a vontade não é mais uma faculdade distinta da mente, ela é uma percepção resultante de um ato deliberado. O deslocamento operado por Hume não é pequeno. Entre os filósofos de língua inglesa a discussão deita raízes no século XVII, com a polêmica entre Hobbes e o bispo de Derry, John Bramhall, e se estende até o século XIX. No correr de mais de um século de discussão, a controvérsia gira em torno de duas posições antinômicas: a determinação da vontade causas que the sejam externas (posição atribuída por Harris a Hobbes e Anthony Collins, por exemplo) e a possibilidade de uma autodeterminação da vontade.

Mesmo no caso dos defensores do livre-arbítrio, porém, nem sempre é negada a existência de motivos que devem ser pesados por essa faculdade. Mas, a livre escolha, para os mais radicais como William King, consistiria numa indiferença total dessa faculdade em relação a seus motivos _numa liberdade de decidir até mesmo contra eles. Em todo caso, nem os defensores do determinismo, nem os advogados do livre-arbítrio discordavam da tese de que a vontade é distinta demais faculdades humanas ${ }^{191}$.

É justamente esse deslocamento que determina a visada característica da filosofia moral de Hume. O filósofo que examina a moral dessa maneira não mais dá destaque à volição propriamente, mas considera a ação e seus motivos como seu principal objeto. Esse parece ser o sentido geral da defesa do método experimental na seção I, da Investigação sobre os Princípios da Moral: "como essa é uma questão de fato e não de ciência abstrata, só poderemos esperar sucesso seguindo o método experimental e deduzindo máximas gerais da comparação de exemplos particulares." (2a Investigação, p. 174) ${ }^{192}$ Assim, a filosofia

\footnotetext{
${ }^{191}$ Sobre isso, cf. Harris, Of Liberty and Necessity, introdução e caps. 2-3.

${ }^{192}$ Citamos segundo a edição Nidditch. Oxford University Press, 1975.
} 
moral baseada no método experimental buscará localizar relações uniformes entre motivos e ação de modo a extrair daí as suas leis gerais.

Mas, além disso, a nova definição de necessidade apresentada por Hume impõe novas exigências ao cientista e ao filósofo. Ela os obriga a se tornarem mais cuidadosos em seu exame da experiência, ela impõe certo ideal de precisão. Como vimos, as questões de fato, das quais tratam todas as ciências, exceto as matemáticas, admitem graus distintos de regularidade. Aonde o fenômeno não corresponde às expectativas, quando ele se apresenta de forma irregular e inesperada, será preciso refazer os experimentos, identificar causas que passaram despercebidas ou que interferiram na série observada inicialmente.

O filósofo experimental em geral é, portanto, obrigado a recortar com maior precisão seu campo de fenômenos. Distinguindo tudo aquilo que é circunstância relevante para a produção dos eventos que pretende explicar. Novamente é importante lembrar a função das Regras para se Julgar sobre Causas e Efeitos. Esse receituário oferecido por Hume ao cientista e ao filósofo, quase no final da parte 3, do livro I, do Tratado, pressupõe os resultados da análise da relação causal, considera o problema das probabilidades, ao prescrever orientações para o filósofo experimental. As oito regras que o compõem formam, diz Hume, a "única LÓGICA que devo empregar em meu raciocínio". São elas que ensinam qual o recorte a ser operado na experiência quando se quer explicar a produção de um fenômeno.

As regras vêm para solucionar uma dificuldade gerada pelo fato de que não nos guiamos mais por uma concepção de necessidade derivada da matemática, que permitia distinguir entre necessário e contingente, e eliminar o segundo do campo da ciência. Considerada apenas em termos de conjunção constante, a necessidade se mantém intacta, mesmo quando nos deparamos com uma anomalia. Assim, torna-se 
mais trabalhoso comentar o campo da experiência, pois, o fenômeno irregular não será de pronto eliminado da ciência. Em vez disso, a anomalia deverá chamar a atenção do filósofo experimental que deve redobrar seus esforços na determinação precisa das causas.

Não há na natureza algum fenômeno que não seja composto e modificado por tantas circunstâncias diferentes que, para chegarmos ao ponto decisivo, devemos separar dele cuidadosamente tudo o que é supérfluo e investigar, por meio de novos experimentos, se cada circunstância particular do primeiro experimento lhe era ou não essencial. ( $T N H$, p. 175)

A esse espectador da natureza, que é o filosofo experimental, cabe desembaralhar as circunstâncias sob as quais o fenômeno se apresenta e separar o que realmente condiciona o efeito e o que é irrelevante em sua explicação. Evidentemente, que não se trata aqui de entender essas condições como determinações ontológicas. O filósofo deve apenas decompor as séries causais de modo a explicitar quais as conjunções constantes que de fato levam-nos a pensar no efeito quando estamos diante das causas.

Vistas sob essa perspectiva as ciências que versam sobre fatos e existências devem ser ciências do detalhe. O termo "circunstância", empregado por Hume em diversas ocasiões, chama a atenção para esse fato. Como nota Malherbe ${ }^{193}$, em um ensaio acerca do uso desse vocábulo na filosofia humiana, muitas vezes não designa um fundo irrelevante no qual se localizam os fenômenos estudados por uma determinada ciência. Em vez disso, muitas vezes ele exprime a "articulação de diferentes planos de causalidade e a determinação pela qual as causas operam ${ }^{194 " .}$ As circunstâncias devem entrar na conta do

\footnotetext{
${ }^{193}$ Cf. Malherbe, Michel, La Notion de Circonstance chez David Hume, In: Hume Studies, vol. XII, n०2, novembro de 1983.

${ }^{194} \mathrm{Cf}$. Malherbe, Michel, La Notion de Circonstance chez David Hume, p. 130.
} 
filósofo experimental, na medida, em que engendram suas próprias séries causais e podem interferir nas séries causais em que está inscrito o conjunto de fenômenos que se pretende estudar. Elas formam um fundo que não é passivo. Pelo contrário, cada uma delas pode fazer variar a intensidade de um efeito, como no caso da crença, alterar uma percepção, como no caso do doente que tem seu paladar modificado ${ }^{195}$, ou ainda transformar uma paixão calma em uma paixão violenta e viceversa ${ }^{196}$. Nessa medida, as circunstâncias podem contribuir para reforçar uma uniformidade, assim, como podem fornecer os motivos pelos quais a uniformidade da natureza foi aparentemente interrompida neste ou naquele caso. A necessidade moral, no entanto, não se interrompe, pois, as próprias circunstâncias operam, também, de modo necessário ${ }^{197}$.

Por isso, é preciso distinguir quais delas alteram os resultados de uma série causal e quais delas não produzem qualquer variação. Essa é a função atribuída às "regras gerais", tais como as que mencionamos acima. É graças a essas normas que "se formam segundo a natureza do entendimento, e conforme a experiência de suas operações nos juízos que formamos acerca dos objetos" que, de acordo com Hume, "aprendemos a distinguir as circunstâncias acidentais das causas eficientes ${ }^{198 " .}$. Trata-se de distinguir entre aquelas circunstâncias que afetam a imaginação, mas são meramente acessórias, e aquelas que são parte da causa eficiente e, portanto, devem entrar em conta em nossos juízos acerca do caso estudado. E mesmo as circunstâncias que

\footnotetext{
195 Sobre esse exemplo cf. $T N H$, p. 226.

196 Sobre isto cf. $T N H$, p. 438: "O que torna as coisas ainda mais incertas é que uma paixão calma pode facilmente ser transformada numa paixão violenta, por uma mudança de temperamento ou das circunstâncias e situação do objeto ou ainda por extrair força de uma paixão que a acompanha, pelo costume ou por excitar a imaginação."

${ }^{197}$ Sobre isso, cf. De Caracteres Nacionais, In: Ensaios Morais, Políticos e Literários, p. 198.

198 Sobre isto cf. TNH, p. 149. Vale notar ainda acerca desse tema que o uso do termo acidental aqui parece inteiramente esvaziado de conteúdo ontológico, designando apenas aquilo que é acessório e não interfere nos fenômenos que se pretende estudar.
} 
não entram, por assim dizer, nas causas eficientes fornecem um fundo a partir do qual a uniformidade pode ser reconhecida em meio à variedade.

Essa concepção do trabalho do cientista e do filósofo implica certas diferenças de uma ciência em relação à outra. Se essa tarefa é difícil para o filósofo da natureza, que trabalha com objetos mensuráveis e cujos experimentos podem ser mais facilmente reproduzidos, ela é ainda mais trabalhosa na moral.

Ora, se isso ocorre mesmo na filosofia da natureza, o que dizer da filosofia moral, na qual se encontram circunstâncias muito mais complexas e as opiniões e sentimentos indispensáveis às operações da mente são tão implícitos e obscuros que freqüentemente escapam ao nosso mais rigoroso escrutínio, permanecendo não somente inexplicáveis em suas causas mas também desconhecidos em sua existência! (TNH, p. 175)

Se a filosofia moral parece mais obscura e incerta que a filosofia da natureza não é porque seu objeto seja menos contingente ou inconstante por natureza. É apenas por que na moral a mistura de circunstâncias é mais intrincada e o recorte experimental demanda mais esforço.

Esse recorte é mais difícil e demanda maior grau de detalhe na filosofia moral porque diversas variáveis podem interferir na conjunção entre motivo e ação sem, no entanto, colocar em risco os princípios da natureza humana. Pois, também, a interferência de toda circunstância é pautada pela mesma necessidade e regularidade a partir das quais podemos inferir os princípios da natureza humana.

As diferentes condições sociais influenciam as condições internas e externas, e essas diferentes condições decorrem necessariamente, posto que uniformemente, dos princípios uniformes e necessários da natureza humana. Os homens não podem viver sem sociedade, nem tampouco se associar sem 
governo. O governo cria distinções de propriedade e estabelece as diferentes classes de homens. Isso produz a indústria, o comércio, as manufaturas, ações judiciais, guerras, ligas alianças, expedições, viagens, cidades, frotas de navios, portos e demais ações e objetos que causam a diversidade ao mesmo tempo em que mantêm a uniformidade da vida humana. (TNH, p. 402)

O objeto da filosofia moral é mais escorregadio que o da física porque é mais intrincado e embaralhado, não porque é menos determinado pela necessidade causal. Sua compreensão demanda que seja considerada a interação de fatores complexos.

O filósofo moral deve levar em conta o modo como interferem as instituições de cada nação, os eventos, as distinções de classe, as formas de governo, as maneiras das épocas e das nações, o caráter e o temperamento dos agentes, e as paixões. Mas em meio a essa variedade encontrará regularidades recorrentes que the fornecerão os princípios constantes da natureza humana.

Queres conhecer os sentimentos, inclinações e modos de vida dos romanos? Estudes o temperamento e as ações dos franceses e dos ingleses, e não estarás muito equivocado em transferir para os primeiros a maior parte do que observastes dos segundos. (Investigação, p.83)

Será possível determinar as inclinações e os sentimentos dos romanos a partir do exemplo dos franceses e dos ingleses. Pois, a despeito das diferenças, há um fundo regular que mantém a natureza humana uniforme.

Em outras palavras, o estudo dessa natureza não elimina a diversidade entre as nações, as épocas e os homens em favor de uma uniformidade monolítica da natureza humana. Pois, é apenas quanto ao mais geral, aos princípios da natureza humana que se encontra essa regularidade. Por isso, é que é apenas na maior parte, que podemos determinar como eram os gregos e os romanos, ao observarmos como 
são os ingleses e os franceses. Na verdade é possível, através de uma espécie de análise detalhista, atingir graus maiores de precisão na moral. Daí a observação sobre o exagero do vulgo, que abre o ensaio sobre os Caracteres Nacionais:

O vulgo tende a levar ao extremo os caracteres nacionais, e uma vez instituído o princípio de que alguns povos são desonestos, covardes ou ignorantes, não se admite exceção e submete-se cada indivíduo à mesma censura. Homens sensatos condenam juízos tão gerais como esses; mas reconhecem, ao mesmo tempo, que cada nação tem um conjunto peculiar de maneiras e que algumas qualidades particulares podem ser mais pronunciadas num povo do que em seus vizinhos. (De Caracteres Nacionais, p. 197)

A consideração apressada do homem comum generaliza excessivamente as maneiras e qualidades características de uma nação, estendendo-as irrestritamente a cada um dos seus cidadãos. Por isso, por exemplo, para o senso comum um suíço sempre será mais honesto que um irlandês. Em favor do mais geral o vulgo deixa de lado, aquilo que constitui exceção.

Temos bons motivos para esperar mais engenho e jovialidade num francês do que num espanhol, apesar de Cervantes ter nascido na Espanha. É natural supor que um inglês tenha mais conhecimento que um dinamarquês, apesar de Brahe ter nascido na Dinamarca. (De Caracteres Nacionais, p. 198)

É por que desconsidera os efeitos das circunstâncias que o vulgo não dá conta de compreender aquilo que constitui exceção; não é capaz explicar, por assim dizer, o extraordinário. ${ }^{199}$

\footnotetext{
${ }^{199}$ Malherbe afirma que a circunstância permite relativizar as leis gerais. Nós aqui não vamos tão longe, uma vez que Hume utiliza termos bastante fortes para caracterizar o estatuto dessas regularidades e da uniformidade da natureza humana. Cf. Malherbe, Science Politique e Historique dans les Essays de David Hume, In: Hume et le Concept de Société Civile, p. 115.
} 
Ora, embora a ciência do homem busque exatamente esses princípios, sempre haverá circunstâncias que produzem variações. E essa variação não elimina a necessidade, na medida em que, quando as circunstâncias produzem efeitos relevantes para o estudo da moral, elas devem entrar no esquema causal de explicação. "Um soldado e um sacerdote, são caracteres diferentes em todas as nações e épocas; e essa diferença funda-se em circunstâncias cuja operação é eterna e inalterável" (Ensaios, De Caracteres Nacionais, p. 198). As "causas morais", que influem na determinação dos caracteres e são decisivas para a compreensão da ação, estão sujeitas a uma necessidade tão forte quanto as causas físicas. Assim, quanto mais capazes formos de descer a um nível de profundidade maior na identificação dessas causas, mais completa será nossa filosofia moral. Evidentemente, essa concepção da moral não enfraquece a uniformidade da natureza humana nem a necessidade moral. Vista desse modo ela apenas torna a ciência da natureza humana mais complexa e laboriosa, demandando uma análise fina e detalhista.

Com efeito, essa ciência exige a consideração da uniformidade em meio à variedade. Pois, é por ela que chegamos às leis mais gerais dessa ciência e através dela que podemos observar uma certa plasticidade da natureza humana. Assim, por exemplo, a partir da constatação de que os homens de diferentes épocas e nações possuem maneiras e costumes distintos, inferimos que a influência do hábito e da educação molda a mente humana desde a infância. E se consideramos as diferentes disposições correspondentes às distinções entre os sexos, isso torna patente que a natureza Ihes atribuiu caracteres diferentes, cujas marcas são constantes e regulares. ${ }^{200} \mathrm{O}$ terceiro livro do Tratado,

${ }^{200}$ Cf. Investigação, pp. 85-86. 
a $2^{a}$ Investigação e os Ensaios Morais, Políticos e Literários ${ }^{201}$ dão um bom testemunho dessa plasticidade e da tentativa de Hume de conciliála com a exigência, inscrita no modelo de ciência que adota, de poder extrair leis gerais. A natureza humana é uniforme, mas é plástica. Isso significa que certos princípios originais, como o hábito e as relações naturais, interagem de maneira regular com outros fatores, como as instituições e os costumes. De modo que será possível falar, por exemplo, na justiça como uma virtude artificial, sem com isso desfigurar a idéia de uma natureza humana.

No Tratado e a $2^{a}$ Investigação a justiça é exposta como uma espécie de artifício instituído para suprir as limitações inscritas na simpatia e em virtudes naturais como a benevolência, estendendo-as de forma realizar uma inclinação natural para a sociabilidade.

Somos naturalmente parciais para conosco e com nossos amigos: mas somos capazes de aprender a vantagem que resulta de uma conduta mais equânime. Poucos prazeres nos são dados pela mão generosa e liberal da natureza: mas com arte, labor e indústria podemos obtê-los em grande abundância. Daí que as idéias de propriedade se tornem necessárias em toda sociedade civil: daí que a justiça seja útil para o poder público: e somente daí decorre o seu mérito e obrigação moral. (2a Investigação, p.188)

A justiça é um artifício que contribui para realizar uma tendência natural, seu valor está ligado à sua utilidade para a realização dessa inclinação. Dado que, por si mesmas, as virtudes naturais que levam à sociabilidade não são capazes de impelir-nos a superar uma parcialidade que nos é igualmente natural, forjamos a justiça para possibilitar a satisfação de nossa natureza sociável. É através de artifícios como esse

\footnotetext{
${ }^{201}$ Vale notar que nessas obras, sem dúvida alteram-se as perspectivas e os percursos de análise, mas mantém-se a doutrina.
} 
que se formam os governos, elaboram-se as leis e estabelecem-se as instituições com vistas a realizar uma tendência natural.

O homem, tendo nascido numa família, é compelido a permanecer em sociedade por necessidade, por inclinação natural e por hábito. A mesma criatura, em seu progresso ulterior, é levada a estabelecer uma sociedade política para a administração da justiça; sem ela não pode haver paz, segurança ou relacionamento entre os homens. Devemos, por isso, considerar que o vasto aparato do nosso governo não tem outro objetivo ou propósito último senão a distribuição de justiça ou, em outras palavras, a sustentação dos doze juízes. (Da Origem do Governo, p. 37)

Esse trecho do ensaio Da Origem do Governo marca bem, diga-se de passagem, a diferença entre Hobbes e Hume. Pois, se para o primeiro a instituição do estado visa à superação do estado de natureza, para o segundo esse movimento tem o sentido de realizar uma tendência natural ${ }^{202}$.

E é possível afirmar que a natureza se realiza através da arte porque a distinção entre artifício e natureza não é formulada por Hume como uma oposição irreconciliável. Em vez disso, essa oposição se dilui numa gradação. Por isso, certos artifícios podem funcionar como, por assim dizer, uma "segunda natureza". Trata-se de um refinamento que deve ser considerado na ciência do homem. O termo "natural" é escorregadio e geralmente compreendido de várias maneiras, todas elas enganosas e equivocadas. Por um lado, essa palavra pode ser definida por oposição ao que é raro ou inusual. Essa distinção, porém, é de pouca utilidade e revela-se superficial. A diferença entre o raro e o freqüente, o inusual e o usual, "depende do número de exemplos que observamos, e como esse número pode diminuir ou aumentar gradualmente, é impossível fixar limites exatos entre os dois" (TNH, p. 474) Não é por aqui que poderemos distinguir as duas coisas. Afinal, em

${ }^{202}$ Sobre isso ver também $2^{\mathrm{a}}$ Investigação, p.214. 
se tratando de uma gradação qual o padrão que poderíamos empregar para demarcar exatamente aonde começa o domínio do freqüente e do raro?

O natural é por vezes concebido em contraste com o artifício. O problema aqui é que ao realizarmos essa distinção "prontamente esquecemos que os desígnios, projetos e objetivos dos homens são princípios tão necessários em sua operação quanto calor e frio, úmido e seco." (TNH, p. 474) A suposta contrariedade entre natural e artificial descura do fato de que a mesma necessidade se aplica ao campo da ação e ao campo da natureza. Ela se funda na ilusão de que nossos atos são inteiramente livres e, nessa medida, distintos daquilo que é determinado pela necessidade da natureza ${ }^{203}$. Assim, a distinção entre natural e artificial depende de que se admita uma distinção prévia entre causalidade natural e a causalidade por liberdade - a qual, como tentamos mostrar, Hume recusa. Portanto, natureza e artifício não são opostos para Hume. E a rejeição dessa oposição é importante, pois ela permite pensar o refinamento do homem e dar conta das variações da natureza humana em meio a suas regularidades ${ }^{204}$.

Ante esse quadro é que a história adquire sua importância no estudo da natureza humana. Por um lado, essa disciplina torna palpáveis, ilustra e confirma as teses filosóficas do autor. Por outro, mais importante, ela permite observar a uniformidade da natureza humana, isolar seus princípios mais gerais e acompanhar sua modulação através de diversos graus de refinamento ${ }^{205}$.

\footnotetext{
203 Cf. TNH, pp. 474-475.

${ }^{204}$ Vale observar que o refinamento se dá nas instâncias das maneiras, da política e do gosto.

${ }^{205}$ Em artigo intitulado Hume, History and Human Nature, S.K. Wertz sai em defesa de Hume contra críticos que apontariam no autor da História da Inglaterra, uma certa arbitrariedade inscrita na tese da uniformidade da natureza humana. Segundo esses autores, que Wertz combate, essa tese humiana não só implicaria anacronismos, como indicaria um certo dogmatismo da parte do filósofo escocês. Para eles, ao fazer história, Hume insistiria em privilegiar a semelhança, justamente onde as diferenças são mais patentes. Não há como discordar de Wertz quanto ao equívoco desses comentadores. Mesmo assim, a solução desse comentador tampouco parece satisfatória, uma vez que ela conserva a distinção entre
} 
Esses registros de guerras, intrigas, facções e revoluções, são coleções de experimentos, pelos quais o político ou o filósofo moral fixam os princípios de sua ciência; da mesma forma que o filósofo natural se familiariza com a natureza das plantas, minerais e outros objetos externos, através dos experimentos que realiza sobre eles. (Investigação, pp. 83-84)

Quanto mais completas forem as narrativas históricas, mais rico será o repertório de circunstâncias que se revela ao filósofo moral, bem como mais patentes serão as regularidades que se pode identificar em meio a tal variedade de refinamentos. Conforme Hume escreve no ensaio Do Estudo da História: "Devo acrescentar que a história não só é parte valiosa do conhecimento, como abre as portas para muitas outras partes e fornece materiais para a maioria das ciências". (Do Estudo da História, In: Ensaios, p. 566). Esse uso é observável, por exemplo, no ensaio $D a$ Liberdade de Imprensa. Nesse texto, a partir da consideração de uma dada realidade histórica, comparada com outras épocas e nações, é possível identificar aquilo que ela revela como lei geral e aquilo que deve ser tomado como específico ${ }^{206}$. Nesse texto, toma-se como ponto de partida a liberdade sui generis de que os britânicos desfrutam para "censurar abertamente cada medida proposta pelo rei ou por seus ministros."(Ensaios Morais, Políticos e Literários, 2, p. 10). O contexto ao qual o ensaio se reporta veladamente refere-se, como indica Malherbe, à tensão política e à controvérsia criadas pela forte oposição às políticas de Sir Robert Walpole, cujo longo ministério durou 21 $\operatorname{anos}^{207}$. A liberdade britânica será comparada com a de Veneza e a da

necessidade física e necessidade moral, um análogo da primeira cuja peculiaridade seria admitir certa indeterminação. Essa diferenciação, conforme tentamos indicar, Hume põe por terra ao tratar da liberdade. "Hume atribui necessidade moral a grande parte do comportamento humano. É aqui que Hume admite a contingência." (Hume, History and Human Nature, In: Journal of History of Ideas, p. 489)

${ }^{206}$ É importante deixar claro ao leitor que não pretendemos realizar aqui uma análise completa para o ensaio Da Liberdade de Imprensa. Trata-se apenas de utilizá-lo a título de ilustração do uso da história.

${ }^{207} \mathrm{Cf}$. Malherbe, Science Politique e Historique dans les Essays de David Hume, In: Hume et le Concept de Société Civile, p. 116-118. 
Holanda, e com a da França e a da Espanha, de modo a verificar o diagnóstico segundo o qual a liberdade da imprensa inglesa deriva da forma mista do governo britânico, a qual "não é nem inteiramente monárquica, nem republicana". Construído dessa forma, o argumento permite a Hume explicar a situação particular da Grã-Bretanha, ao mesmo tempo em que tira conclusões gerais sobre a liberdade nas repúblicas e nas monarquias, a partir dos casos supracitados. Uma comparação adicional com o regime de Roma Antiga, que misturava despotismo e liberdade, servirá para determinar melhor a situação peculiar dos britânicos ${ }^{208}$.

Assim, a história além de entreter e ensinar, como ressalta o ensaio Do Estudo da História, ${ }^{209}$ vem a resolver um problema metodológico. Essa disciplina é fundamental porque é através dela que podemos solucionar uma dificuldade identificada desde a introdução do Tratado. Com efeito, na ciência do homem não é possível recorrer a experimentos da mesma maneira que a filosofia da natureza. O filósofo moral não pode realizá-los de maneira "deliberada e premeditada" sem comprometer a justa observação do campo de fenômenos que se propõe a estudar.

\begin{abstract}
Mas, se eu quisesse esclarecer da mesma forma uma dúvida no domínio da filosofia moral colocando-me na mesma situação que aquele que estou considerando, é evidente que essa reflexão e premeditação perturbariam de tal
\end{abstract}

\footnotetext{
${ }^{208} \mathrm{Em}$ outros ensaios, o recurso à história e o balanço entre as circunstâncias particulares e a conclusões gerais é igualmente evidente e, talvez, mais copioso. Esse é o caso, por exemplo, do ensaio intitulado Que a Política pode ser Transformada numa Ciência. Mais extenso, esse texto recorre freqüentemente à narrativa histórica de modo a marcar as variações ao mesmo tempo em que são isoladas constantes. Assim, ele procura demonstrar na política, como nas outras, ciências podemos formular leis gerais. A ênfase de Hume quanto a essa tese é reforçada pelos termos que emprega ao enunciar aquela que é primeira dessas leis: Tão grande é a força de leis e de formas particulares de governo, e tão pequena sua dependência do humores e temperamentos dos homens, que às vezes delas se podem deduzir conseqüências quase tão gerais e certas quanto quaisquer umas daquelas que nos são proporcionadas pelas ciências matemáticas. (Que a política pode ser transformada numa Ciência, p. 16)

${ }^{209}$ Cf. Do Estudo da História, p. 566.
} 
maneira a operação de meus princípios naturais que se tornaria impossível tirar qualquer conclusão correta a respeito do fenômeno. ( $T N H$, p. xix)

Pela história podemos estender consideravelmente nosso repertório de experimentos e observar o refinamento das maneiras e o declínio das nações e dos homens ao longo do tempo. A narrativa dos fatos e eventos que o historiador reúne expõe as séries causais que dão sentido a esses processos.

Mas a espécie mais usual de conexão entre os diferentes eventos que entram numa composição narrativa é a de causa e efeito, quando o historiador traça séries de ações de acordo com sua ordem natural, remonta até seus princípios e molas secretas, e delineia suas mais remotas conseqüências. (...) Ele vê que o conhecimento das causas é não somente o mais satisfatório, dado que essa relação ou conexão é a mais forte de todas, como também o mais instrutivo, dado apenas com um tal conhecimento podemos controlar os eventos e governar o futuro. (Ensaios Filosóficos, pp. 35-36)

Assim, é ao historiador que deverão recorrer o filósofo, o político e o crítico, quando forem buscar as a matéria prima de seus saberes. E a história adquire seu estatuto de ciência porque nela o autor procede com base na mesma necessidade que o filósofo da natureza. É essa necessidade, calcada na conjunção constante e no hábito, que articula seu discurso e confere um sentido aos eventos que $o$ historiador narra ${ }^{210}$.

Mas, não é só por seu caráter extensivo que a perspectiva histórica se constitui como uma fonte privilegiada para o estudo da natureza humana. O ponto de vista que a história nos oferece é também o mais equilibrado e o mais adequado para o conhecimento da virtude e o refinamento de nosso caráter. Afinal, ainda que seja verdade que pela experiência da vida comum, pela "prática do mundo", podemos

\footnotetext{
${ }^{210}$ Essa observação sobre a relação de causa e efeito parece valer para todas as ciências que hoje chamaríamos de empíricas. Afinal é também pela causalidade e pela conexão que ela leva a
} 
aprender muito acerca dos caracteres, temperamentos e maneiras dos homens, nosso ponto de vista é, nessa circunstância, sempre determinado por nosso interesse, ele é sempre parcial. Assim, um homem de negócios, sempre julgará sobre esses assuntos tendo em vista os resultados visados por sua paixão e interesse. Na filosofia, por outro lado, corremos o risco de considerar esses objetos de um ponto de vista excessivamente distante e abstrato que mantém a mente "fria e imóvel", impedindo a correta percepção da diferença entre a virtude e o vício.

É a história que tempera esses dois extremos, pois, o discurso do historiador se situa em algum lugar entre eles.

A história se mantém no justo meio entre esses extremos e põe os objetos no seu verdadeiro ponto de vista. Os que escrevem história têm, como seus leitores, interesse suficiente pelos caracteres e eventos para ter vivo sentimento de censura ou de elogio e, ao mesmo tempo, não têm nenhum interesse ou preocupação particular para perverter o seu julgamento. (Do Estudo da História, p. 568)

O melhor exemplo disso é Maquiavel. Esse autor que, do ponto de vista de Hume, revela desconsideração pela virtude ao falar como político, quando discursa como historiador revela-se uma calorosa aprovação dessa qualidade. No estudo da história, portanto, reside não só a possibilidade de uma extensão da experiência, mas, também, de um refinamento dos sentimentos do leitor, seja ele filósofo ou homem comum. No caso do filósofo esse refinamento permitirá uma acuidade e uma precisão maiores, bem como um salutar interesse pela virtude.

imaginação a estabelecer entre seus objetos que o movimento dos corpos, os fenômenos médicos e outros tantos objetos da ciência deixam de ser uma simples coleção de percepções. 


\section{Conclusão}

O leitor que termina de percorrer o livro I do Tratado poderia muito bem suspeitar da impossibilidade da realização da ciência da natureza humana que Hume prometera na introdução da obra. Afinal, apesar das observações apaziguadoras sobre o ceticismo mitigado, fornecidas pelo autor na conclusão do livro I, é de se perguntar como é possível que da demolição sistemática de conceitos da metafísica clássica possa sair um saber que mereça ser honrado com o título de ciência. Afinal, Hume não só acaba por declarar a ilegitimidade filosófica da tese da dupla existência, em torno da qual se constituía boa parte dos alicerces da filosofia moderna, como recusa a possibilidade de uma adesão sem restrições ao senso comum no que tange a existência de objetos externos. Esse movimento de desmonte da metafísica clássica em suas várias feições tem, como vimos, início na análise da causalidade e chega a seu termo com a redução da noção de sujeito a uma crença natural.

É verdade que o saldo que se extrai do livro I do Tratado possui um aspecto negativo. Afinal, ao remeter o léxico conceitual da metafísica a uma série de crenças naturais e operações redobradas da fantasia, Hume nega direito de cidadania a boa parte das noções metafísicas sobre as quais se apóia a filosofia moderna, seja ela cartesiana ou empirista. Mas esse movimento aponta para uma face, por assim dizer, positiva do pensamento humiano. Com efeito, a recusa da metafísica clássica no Tratado e pela Investigação como que limpa o terreno para o estudo da história, das paixões, da moral, da política e da crítica. Essa dupla operação, que vai aos poucos colocando em xeque conceitos que articulam e possibilitam o conhecimento na metafísica clássica e demanda a sua substituição, é o desdobramento rigoroso de um empirismo que se propõe a comentar a experiência a partir do 
princípio da diferença e da separação e se limita a um estrito fenomenismo. Duas posições que, diga-se de passagem, comandam a filosofia humiana desde formulação da doutrina das impressões e das idéias e estavam implícitas já na distinção fundamental entre questões de fato e relações de idéias. São o princípio da diferença e da separação e o fenomenismo que dão o tom das análises da causalidade, da identidade pessoal e das existências externas. É tomando-os como ponto de partida que Hume vai se colocar em posição de criticar a metafísica e sugerir uma nova concepção de cientificidade.

À semelhança do que Newton fizera na física, Hume pretende eliminar os entraves e as dificuldades impostos pelas chamadas "hipóteses metafísicas".

Enquanto a imaginação ardente for admitida em filosofia e as hipóteses forem aceitas meramente por serem especiosas ou agradáveis, nunca teremos quaisquer princípios firmes ou sentimentos adequados à experiência e à prática comum. Mas, se essas hipóteses forem algum dia removidas, poderemos ter esperanças de estabelecer um sistema, ou que seja conjunto de opiniões satisfatórias para a mente humana e que resistam ao teste do exame mais crítico. (TNH, p. 272)

O resultado do livro I é que, ao rejeitar as concepções clássicas de sujeito, alma, substância e forma substancial, acidente, dupla existência e conexão necessária, Hume nega praticamente toda uma epistème e coloca o problema do conhecimento em novos termos. Todas essas manobras se inscrevem de forma consistente no projeto humiano de erigir uma ciência do homem. Pois, por um lado trata-se de eliminar conceitos e padrões que põem dificuldades e obstáculos à filosofia e, especialmente, à moral. E, por outro, de elaborar uma concepção de conhecimento que permita a atribuição da rubrica de ciência ao estudo das paixões, da moral, da política sem que esse estudo tenha de 
remeter-se obrigatoriamente a um princípio de razão ou a uma substância para adquirir direito de cidadania. Assim, antes de ratificar leituras que atribuem a Hume apenas o papel de destruidor da metafísica, ou dar assentimento aqules que viram em sua filosofia um pensamento que impossibilita toda ciência, é preciso ver de que modo a análise da metafísica empreendida por Hume abre perspectivas em vez de fechá-las.

É nas seções sobre a liberdade e a necessidade, como tentamos indicar, que se pode vislumbrar tais perspectivas. Considerando-se o quadro desenhado pelo livro I do Tratado e pela Investigação não é difícil ver o que se ganhou ao criticar a metafísica e defender a homogeneização da necessidade moral e da necessidade física. Afinal, não há mal nenhum em reconhecer que há uma necessidade e uma regularidade que admitem graus no campo das questões de fato. Pelo contrário, ao fazê-lo temos mais a ganhar do que a perder. Pois, se não associarmos essa gradação à contingência, não enfraquecemos a necessidade física e, ao mesmo tempo, abrimos todo um novo campo para a ciência.

A homogeneidade dos campos da necessidade física e da necessidade moral é uma notícia auspiciosa. Livres da carga ontológica que pesava excessivamente sobre a causalidade os filósofos e moralistas que consultarem a experiência poderão comentar o campo de fenômenos que pretendem estudar considerando a variações de suas regularidades, sem abrir mão da cientificidade de seus saberes. Pois, se a necessidade em geral não é mais concebida à imagem da necessidade matemática, e a ciência não está mais obrigada a reconstituir conexões reais entre os objetos, é possível comentar a anomalia do ponto de vista da gradação que separa a prova da probabilidade, e o raro do freqüente.

Pois, é na medida em que o hábito e a conjunção constante agem sobre essa faculdade que ela confere um sentido e uma unidade à 
experiência. Assim, não é porque a regularidade desses campos não se apresenta em sua inteireza ao pesquisador, que ele deve abandoná-los. Antes será preciso que ele redobre seus esforços, partindo da suposição razoável de que algo precisa ser corrigido em sua análise da "mistura de causas" que interfere no fenômeno.

É certo que Hume continuará a empregar termos como "contingente" e "necessário", mas agora eles estão inteiramente destituídos do peso ontológico que a tradição lhes conferia. 0 "necessário" refere-se apenas àqueles fenômenos que foram submetidos a um recorte experimental claro o suficiente para afastar quaisquer dúvidas a respeito de sua ocorrência. Ele designa apenas uma afecção que determina a mente a passar de um objeto a outro, sem se pronunciar a respeito das conexões reais entre esses objetos. E o "contingente" designa aquilo que ou ainda não foi adequadamente determinado pela análise das causas, ou que não interfere de modo considerável na série causal que se pretende verificar.

É no cenário que se abre a partir daqui que faz sentido o ceticismo mitigado de Hume. Com efeito, desobrigado de fornecer as razões últimas do comportamento dos objetos não importa que o filósofo não conheça a substância do eu ou dos corpos externos. Não importa, tampouco, que ele continue a crer nesses dois gêneros de objetos, sem poder justificar filosoficamente essas crenças. Pois, lendo a experiência segundo um outro jargão que não o da metafísica, ele pode interpretála, sem problemas, recorrendo apenas à escala de regularidades dos fenômenos.

É bom, portanto, que a conjunção constante determine a imaginação em suas inferências da mesma forma, seja na física, seja na moral. Se fosse diferente, a história, a política, a crítica e a filosofia moral estariam excluídas do campo da ciência. Pois, é na medida em que essas duas circunstâncias agem sobre essa faculdade que ela 
confere um sentido e uma unidade à experiência. Sem essa afecção que está na base da idéia de necessidade a ciência da natureza humana estaria irremediavelmente comprometida. 


\section{BIBLIOGRAFIA}

\section{FONTES PRIMÁRIAS:}

\section{Obras de David Hume}

A Treatise of Human Nature, edição de Selby-Bigge, Oxford, Clarendon Press, 1957.

Tratado da Natureza Humana, Trad. Débora Danowski, Editora Unesp e Imprensa Oficial, São Paulo, 2000.

An Inquiry concerning Human Understanding, In.: Hume Inquiries, edição de Selby-Bigge, Oxford, Clarendon Press, 1957.

Uma Investigação sobre o Entendimento Humano, In: Investigações sobre o Entendimento Humano e sobre os Princípios da Moral, Trad. José Oscar de Almeida Marques, Editora Unesp, São Paulo, 2003.

An Inquiry concerning the Principles of Moral, In.: Hume Inquiries, edição de Selby-Bigge, Oxford, Clarendon Press, 1957.

Uma Investigação sobre os Princípios da Moral, In: Investigações sobre o Entendimento Humano e sobre os Princípios da Moral, Trad. José Oscar de Almeida Marques, Editora Unesp, São Paulo, 2003

Dialogues concerning Natural Religion, in.: Dialogues and Natural History of Religion, Oxford University Press, Nova Iorque, 1993.

Dissertation on Passions, In: Four Dissertations, Thoemmes Press, Bristol, 1992.

Essays Moral, Political, and Literary, Liberty Fund. Indianapolis, 1985.

Natural History of Religion, In: Four Dissertations, Thoemmes Press, Bristol, 1995.

The Letters of David Hume, ed. J. Y. T. Greig, Clarendon Press, Oxford, 1932.

\section{Obras de outros autores:}


Berkeley, George, A Treatise concerning the Principles of Human Knowledge, In: The Works of George Berkeley Bishop of Cloyne, Kraus Reprint, Kraus-Thomson Organization Ltd., Liechtenstein, 1979.

Three Dialogues between Hylas and Philonous, In: The Works of George Berkeley Bishop of Cloyne, Kraus Reprint, Kraus-Thomson Organization Ltd., Liechtenstein, 1979.

Descartes, René, Meditações Metafísicas, trad. J. Guinsburg e Bento Prado Júnior, Difel, São Paulo, 1962.

Princípios da Filosofia, Tradução dos membros do Seminário Filosofia da Linguagem, Guido Antônio de Almeida (coord.), Editora UFRJ, Rio de Janeiro, 2002.

Regras para a Direç̧ão do Espírito, Trad. João Gama, Edições 70, Lisboa,m 1985.

Hutcheson, Francis, An Inquiry Concerning the Original of our Ideas of Beauty and Virtue, Lincoln-Rembrandt Publishing.

Locke, John, An Essay concerning Human Understanding, Penguin Books, Londres, 1997.

Reid, Thomas, An Inquiry into the Human Mind ando $n$ the Principles of Common Sense, In: Inquiry and Essays, Hackett Publishing Company, Indianapolis, 1993.

Smith, Adam, Teoria dos Sentimentos Morais, trad. Lya Luft, Martins Fontes, São Paulo, 1999.

Lectures on rhetoric and Belles Letres, Liberty Fund, Indianapolis, 1992.

FONTES SECUNDÁRIAS:

Obras de Comentadores 
Alférri, Pierre, Guillaume d'Ockham - Le Singulier , Les Éditions de Minuite, Paris, 1989.

Baier, Annette C., A Progress of Sentiments, Harvard University Press, 1991.

Bennett, Jonathan, Locke, Berkeley, Hume : Central Themes, Clarendon Press, Oxford, 1971.

Box, M. A., The Suasive Art of David Hume, Princeton University Press, Princeton, 1990.

Broadie, Alexander, The Scottish Enlightenment, Birlinn, Edimburgo, 2005.

Bryson, Gladys, Man and Society: The Scottish Inquiry of the Eighteenth Century, Augustus M. Kelley Publishers, Nova Iorque, 1968.

Buckle, Stephen, Hume's Enlightenment Tract, Oxford University Press, Oxford, 2001.

Cassirer, Ernst, The Philosophy of the Enlightenment, Princeton University Press, Princeton, Nova Jersey, 1951.

Cléro, Jean-Pierre, Hume, Vrin, Paris, 1998.

Darwall, Stephen, The British Moralists and the Internal Ought, Cambridge University Press, Cambridge , 1995.

Deleuze, Gilles, Empirisme et Subjectivité, Presses Universitaires de France, Paris, 1980.

Flew, Anthony, Hume's Philosophy of Belief:a Study of his First Inquiry, Routledge \& Keagan Paul, Londres, 1961.

David Hume Philosopher of Moral Science, Blackwell Publishers, Oxford, 1986.

Fogelin, Robert J. Hume's Skepticism in the Treatise of Human Nature, Routledge \& Keagan Paul, Londres, 1985.

Foucault, Michel, As Palavras e as Coisas, Trad. Salma Tannus Muchail, Martins Fontes, São Paulo, 2002. 
Frasca-Spada, Marina, Space and Self in Hume's Treatise, Cambridge University Press, Cambridge, 1998.

Groulez, Marianne, Le Scepticism de Hume: les Dialogues sur la Religion Naturelle, Presses Universitaires de France, Paris, 2005.

Harris, James A., Of Liberty and Necessity, Clarendon Press, Oxford, 2005.

Jones, Peter, Hume's Sentiments: Their Ciceronian and French Context, Edinburgh: Edinburgh University Press, 1982.

Livingston, Donald W., Philosophical Malancholy and Delirium, The University of Chicago Press, Chicago, 1998.

Mackie, J.L., Hume's Moral Theory, Routledge, London, 1980.

Malherb, Michel, La Philosophie Empirist de David Hume, Paris,1983.

Merleau- Ponty, Maurice, Signos, trad. Maria Ermantina Galvão Gomes Pereira, Martins Fontes, São Paulo, 1991.

Michaud, Yves, Hume et la Fin de la Philosophie, Presses Universitaires de France (P.U.F.), Paris, 1983.

Locke, Trad. Lucy Magalhães, Jorge Zahar Editor, Rio de Janeiro, 1991.

Monteiro, João Paulo, Hume e a Epistemologia, Imprensa Nacional, Lisboa, 1982.

Mossner, E.C., The Life of David Hume, Oxford University Press at the Clarendon Press, Oxford, 2001.

Norton, David Fate, David Hume:Common-Sense Moralist, Sceptical Metaphysician, Princeton: Princeton University Press,1982; edição revista, 1984.

Noxon, James, Hume's Philosophical Development, Oxford, Clarendon Press, 1973.

Owen, David, Hume's Reason, Oxford University Press, Oxford, 2002.

Passmore, J., Hume's Intentions, Basic Books, Nova Iorque, 1968. 
Potkay, Adam, The Fate of Eloquence in the Age of Hume, Cornell University Press, Ithaca, 1994.

Price, H.H., Hume's Theory of the External World, Oxford University Press at the Clarendon Press, Oxford, 1940.

Schmidt, Claudia M., Hume: Reason in History, Pennsylvania State University Press, 2003.

Strasser, Mark, Francis Hutcheson's Moral Theory, Longwood Academic, New Hampshire, 1990.

Strawson, Galen, The Secret Connexion: Causation, Realism, and David Hume, Oxford, Clarendon Press, 1989.

Todd, Denis, Imagining Monsters, University of Chicago Press, Chicago, 1995.

Waxman, Wayne, Hume's Theory of Consciousness, Cambridge University Press, Cambridge, 1994.

Willey, Basil, The Eighteenth-Century Background, Penguin Books, Harmondsworth, 1965.

Wright, John P., The Sceptical Realism of David Hume, Manchester University Press, Manchester 1983.

Yolton, John W., Realism and Appearences, Cambridge University Press, Cambridge, 2000.

\section{Artigos, Periódicos e Coletâneas}

Barfoot, Michael, Hume and the Culture of Science in the Early Eighteenth Century, In: Studies in the Philosophy of the Scottish Enlightenment, M.A. Stewart (org.), Clarendon Paperbacks, Oxford, 1991.

Belshaw, Daniel, Hume and Demonstrative Knowledge, In: Hume Studies, vol. XV, no. 1, ed. The Hume Society, Ontario, abril, 1989. 
Brown, Charlotte, From Spectator to Agent: Hume's Theory of Obligation, In: Hume Studies, vol. XX, no.1, ed. The Hume Society, Salt Lake City, abril, 1994.

Budd, Malcom, Hume's Tragic Emotions, In: Hume Studies, vol. XVII, no. 2, ed. The Hume Society, Ontario, novembro, 1991.

Cléro, Jean-Pierre, Le Sens Moral chez Hume, Smith et Bentham, In: Le Sens Moral: une Histoire de la Philosophie Morale de Locke à Kant, Org. Laurent Jaffro, Presses Universitaires de France, Paris, 2000. Le Concept de "Nature Humaine" dans le Traite e et l'Histoire d'Angleterre, In: Hume et le Concept de Société Civile, Claude Gautier (coord.), Presses Universitaires de France, Paris, 2001.

Haakonssen, Knud, Natural Law and Moral Realism: the Scottish Synthesis, In: Studies in the Philosophy of the Scottish Enlightenment, Org: M.A. Stewart, Clarendon Paperbacks, Oxford, 1991.

Immerwhar, John, The Anatomist and the Painter: Continuity of Hume's Treatise and Essays, In: Hume Studies, vol. XVII, no. 1, ed. The Hume Society, Ontario, abril, 1991.

Jaffro, Laurent, La Formation de la Doctrine du Sens Moral: Burnet, Shaftsbury, Hutcheson, In: Le Sens Moral: une Histoire de la Philosophie Morale de Locke à Kant, Org.: Laurent Jaffro, Presses Universitaires de France, Paris, 2000. Transformation du Concept de Imitation de Francis Hutcheson a Adam Smith, In: L'Estethétique: Naît-elle au XVIII Sècle?, Org.: Serge Trottein, Presses Universitaires de France, Paris, 2000.

Lebrun, Gérard, Berkeley ou le Sceptique Malgrè Lui, Trad. Maria Adriana Camargo Cappello, In: A Filosofia e sua História, Carlos Alberto Ribeiro de Moura, Maria Lúcia M. O. Cacciola e Marta Kawano (orgs.), Cosacnaify, São Paulo, 2006. 
A Boutade de Charing-Cross, Trad., Marta Kawano, In: A Filosofia e sua História, Carlos Alberto Ribeiro de Moura, Maria Lúcia M. O. Cacciola e Marta Kawano (orgs.), Cosacnaify, São Paulo, 2006. Losee, John, Hume's Demarcation Project, In: Hume Studies, vol. XVIII, no. 1, ed. The Hume Society, Ontario, abril, 1992.

MacIntyre, Jane L., Hume: Seconde Newton of the Moral Sciences, , In: Hume Studies, vol. XX, no. 1, ed. The Hume Society, Salt Lake City, abril, 1994.

MacRae, Robert, Perceptions, Objects, and the Nature of the Mind, In: Hume Studies, $10^{\text {th }}$ Aniversary Issue, ed. The Hume Society, Ontario, novembro, 1985.

Malherbe, Michel, La Notion de Cinconstance dans la Philosophie de Hume, In: Hume Studies, vol. IX, no. 2, ed. The Hume Society, Ontario, novembro, 1983.

Hume and the Art of Dialogue, In: Hume and Hume's Connexions, M.A Stewart e John P. Wright (orgs.), The Pennsylvania State University Press, Pennsylvania, 1994.

Science politique et Science Historique dans les Essais de David Hume, In: Hume et le Concept de Société Civile, Claude Gautier (coord.), Presses Universitaires de France, Paris, 2001.

Michaud, Yves, How to become a Moderate Skeptic: Hume's Way out of Pyrronism, In: Hume Studies, vo. XI no. 1, ed. The Hume Society, Ontario, abril, 1985.

Moore, James, Natural Law and the Pyrronian Controversy, In: Philosophy and Science in the Scottish Enlightenment, edit. Peter Jones, John Donald Publishers, Edimburgo, 1988.

The Two Systems of Francis Hutcheson: On the Origins of Scottish Enlightenment, In: Studies in the Philosophy of the Scottish Enlightenment, Org: M.A. Stewart, Clarendon Paperbacks, Oxford, 1991. 
Hume and Hutcheson, In: Hume and Hume's Connexions, M.A Stewart e John P. Wright (orgs.), The Pennsylvania State University Press, Pennsylvania, 1994.

Moura, C.A . Ribeiro de, Crítica Humeana da Razão, In: Racionalidade e Crise, Discurso Editorial e Editora UFPR, São Paulo, 2001.

David Hume para além da Epistemologia, In: Racionalidade e Crise, Discurso Editorial e Editora UFPR, São Paulo, 2001.

Norton, Daniel Fate, Hume's Moral Ontology, In: Hume Studies, $10^{\text {th }}$ Aniversary Issue, ed. The Hume Society, Ontario, novembro, 1985.

Owen, David, Hume and the Lockean Background: Induction and the Uniformity Principle, In: Hume Studies, vol. XVIII, no. 2, ed. The Hume Society, Ontario, novembro, 1992.

Hume's Doubts about Probable Reasoning: was Locke the Target?, In: Hume and Hume's Connexions, M.A Stewart e John P. Wright (orgs.), The Pennsylvania State University Press, Pennsylvania, 1994.

Pocock, J.G.A., Hume e a Revolução Americana, In: Linguagens do Ideário Político, Org. Sergio Miceli, Edusp, São Paulo, 2003.

Popkin, Richard H., David Hume: his Pyrrhonism and his Critique of Pyrrhonism, In.: Hume, Critical Essay, ed. V. C. Chappell, University of Notre Dame Press, Notre Dame, Indiana,1966.

Ridge, Michael, Epistemology moralized: David Hume's Practical Epistemology, In: Hume Studies, vo. XXIX no. 2, ed. The Hume Society, Ontario, novembro, 2003.

Robinson, Wade L., One Consequence of Hume's Nominalism, In: Hume Studies, vol. VIII, no.2, ed. The Hume Society, Ontario, novembro, 1982.

Sapadin, Eugene, A Note on Newton, Boyle, and Hume's "Experimental Method", In: Hume Studies, vol. XXIII, no. 2, ed. The Hume Society, Ontario, novembro, 1997. 
Waxman, Wayne, Impressions and Ideas: Vivacity as Verissimilitude, In: Hume Studies, vol. XIX, no. 1, ed. The Hume Society, Ontario, abril, 1993.

Hume's Quandary concerning Personal Identity, In: Hume Studies, vol. XVIII, no. 2, ed. The Hume Society, Ontario, novembro, 1992.

Wilson, Fred, Hume's Cognitive Stoicism, In: Hume Studies, $10^{\text {th }}$ Aniversary Issue, ed. The Hume Society, Ontario, novembro, 1985.

Winkler, Kenneth P., "All is Revolution in Us": Personal Identity in Shaftesbury and Hume, In: Hume Studies, vo. XXVI, no.1, ed. The Hume Society, Ontario, novembro, 2000.

Wood, P.B., David Hume on Thomas Reid's Inquiry into Human Mind and the Principles of Common Sense: A New Letter to Hugh Blair from July 1762, In: Mind, Oxford University Press, 1986.

Wright, John P., Butler and Hume on Habit and Moral Character, In: Hume and Hume's Connexions, M.A Stewart e John P. Wright (orgs.), The Pennsylvania State University Press, Pennsylvania, 1994. 